Review

\title{
The Role of Non-Coding RNAs in the Regulation of the Proto-Oncogene MYC in Different Types of Cancer
}

\author{
Ekaterina Mikhailovna Stasevich ${ }^{1,+}$, Matvey Mikhailovich Murashko ${ }^{2,+}$, Lyudmila Sergeevna Zinevich ${ }^{3} \mathbb{D}$, \\ Denis Eriksonovich Demin 2,*(D) and Anton Markovich Schwartz ${ }^{1,4}$ \\ 1 Center for Precision Genome Editing and Genetic Technologies for Biomedicine, Engelhardt Institute of \\ Molecular Biology, Russian Academy of Sciences, 119991 Moscow, Russia; \\ stasevich.em@phystech.edu (E.M.S.); shvarts@eimb.ru (A.M.S.) \\ 2 Laboratories for the Transmission of Intracellular Signals in Normal and Pathological Conditions, \\ Engelhardt Institute of Molecular Biology, Russian Academy of Sciences, 119991 Moscow, Russia; \\ murashko.mm@phystech.edu \\ 3 Koltsov Institute of Developmental Biology, Russian Academy of Sciences, 119334 Moscow, Russia; \\ lzinevich@gmail.com \\ 4 Department of Molecular and Biological Physics, Moscow Institute of Physics and Technology, \\ 141701 Moscow, Russia \\ * Correspondence: denis.demin@phystech.edu \\ + These authors contributed equally to the manuscript.
}

Citation: Stasevich, E.M.; Murashko, M.M.; Zinevich, L.S.; Demin, D.E.; Schwartz, A.M. The Role of NonCoding RNAs in the Regulation of the Proto-Oncogene MYC in Different Types of Cancer. Biomedicines 2021, 9, 921. https://doi.org/10.3390/ biomedicines 9080921

Academic Editor: Jae Hoon Bahn

Received: 20 June 2021

Accepted: 28 July 2021

Published: 30 July 2021

Publisher's Note: MDPI stays neutral with regard to jurisdictional claims in published maps and institutional affiliations.

Copyright: (c) 2021 by the authors. Licensee MDPI, Basel, Switzerland. This article is an open access article distributed under the terms and conditions of the Creative Commons Attribution (CC BY) license (https:/ / creativecommons.org/licenses/by/ $4.0 /)$
Abstract: Alterations in the expression level of the MYC gene are often found in the cells of various malignant tumors. Overexpressed MYC has been shown to stimulate the main processes of oncogenesis: uncontrolled growth, unlimited cell divisions, avoidance of apoptosis and immune response, changes in cellular metabolism, genomic instability, metastasis, and angiogenesis. Thus, controlling the expression of MYC is considered as an approach for targeted cancer treatment. Since c-Myc is also a crucial regulator of many cellular processes in healthy cells, it is necessary to find ways for selective regulation of MYC expression in tumor cells. Many recent studies have demonstrated that non-coding RNAs play an important role in the regulation of the transcription and translation of this gene and some RNAs directly interact with the c-Myc protein, affecting its stability. In this review, we summarize current data on the regulation of MYC by various non-coding RNAs that can potentially be targeted in specific tumor types.

Keywords: MYC; miRNAs; lncRNA; circRNA; cancer

\section{Introduction}

The MYC family of proto-oncogenes consists of three genes-C-MYC, L-MYC, and NMYC [1]. The name of the family was coined after the discovery of homology between the human gene C-MYC, overexpressed in various tumors, and the oncogene v-Myc, carried by the avian myelocytomatosis virus (myelocytomatosis) [2]. Subsequently, homologs of c-Myc were discovered for humans: N-Myc [3], and L-Myc [4]. This review focuses on the most studied proto-oncogene of this family, C-MYC (or simply MYC).

C-Myc is an extraordinary transcription factor, as it has been shown to affect the expression of up to $15 \%$ of all genes in the human body [5]. It controls the expression of genes involved in a wide range of cellular processes, such as transcription, translation, cell cycle [6,7], cell adhesion [8], and others. Along with other factors of the MYC family, $\mathrm{C}$-Myc has an important role in mammalian embryogenesis, especially in the development of cartilage, the liver, the thymus, submandibular glands, and brown adipose tissue [9-11]. This factor is also crucial for the normal development and activation of various populations of lymphocytes [12-14]. To regulate transcription, c-Myc forms a heterodimer with the transcription factor Max. Together, they can bind to a conserved E-box sequence (CACGTG) to activate or enhance the transcription of various genes. Moreover, c-Myc can bind to other 
transcription factors, such as TBP [15] or ETS2 [16], to DNA methyltransferases, such as Dnmt3a [17], or to histone-modifying enzymes, for example, ASH2L [18]. Overexpression of the MYC gene in various types of tumors is associated with an unfavorable prognosis. In particular, this correlation has been shown for Burkitt's lymphoma $[19,20]$, small cell lung cancer [21], breast cancer [22], and colorectal cancer [23].

Cancer is one of the central topics of modern science and many distinctive features inherent in the development of human cancers are well known. It is characterized by a tendency for rapid uncontrolled growth, an unlimited number of cell divisions, evasion of apoptosis and the immune response, metastasis, abnormal cellular metabolism, genomic instability, and stimulation of angiogenesis [24] (Figure 1).

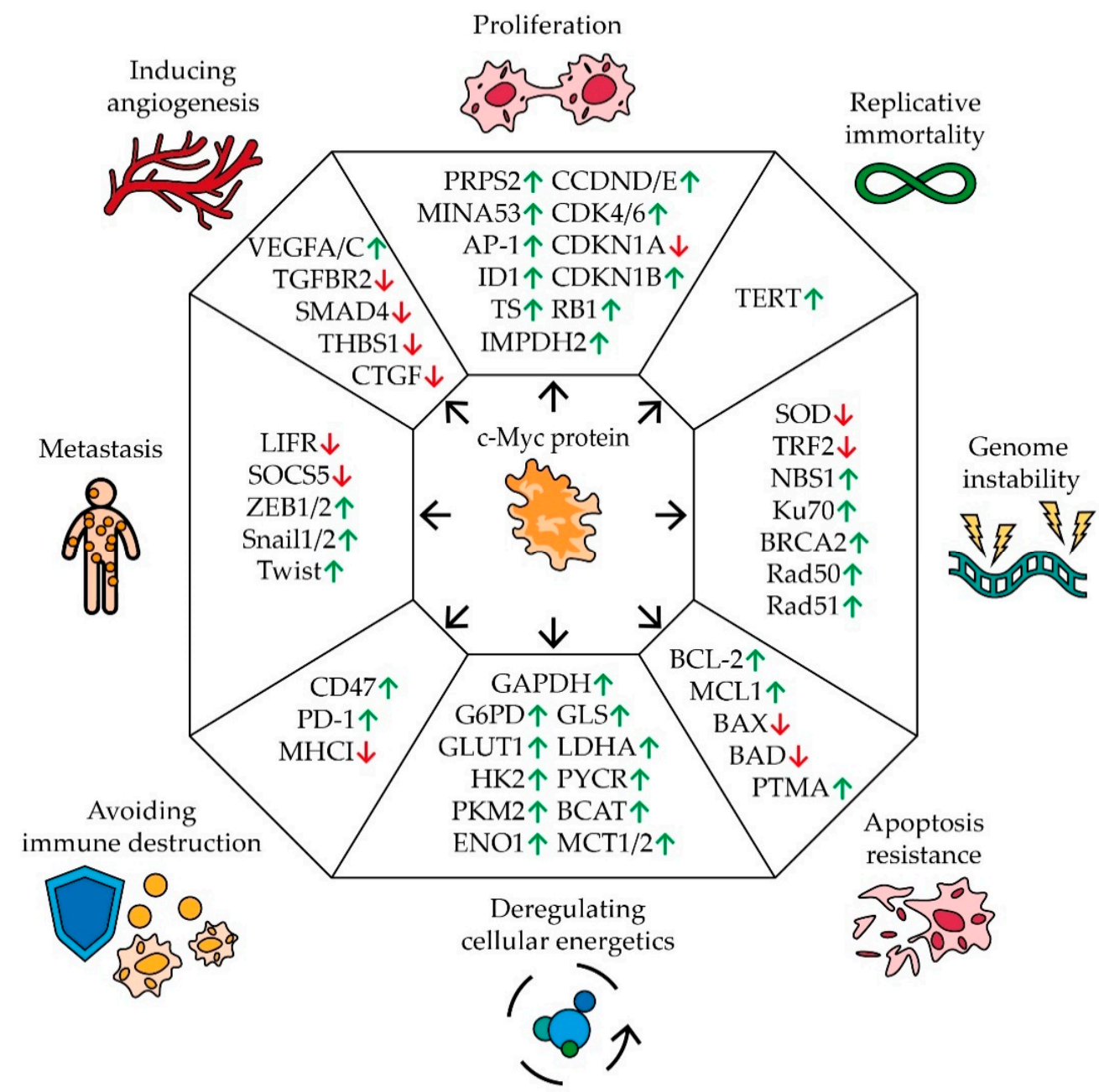

Figure 1. The impact of MYC proto-oncogene on the hallmarks of cancer development. Schematic representation of c-Myc's effect on pivotal genes involved in carcinogenic pathways. Arrows indicate an increase (green) or a decrease (red) in gene expression in response to MYC expression (see text for description and references).

Disruption of the cell division mechanism is one of the main characteristics of malignant tumors. Many studies have demonstrated a correlation between the expression of the MYC gene and the rate of cell proliferation [25-29] (Figure 1). C-Myc controls the expression of a number of key cell cycle regulators by stimulating or suppressing the expression of certain miRNAs. Thus, an increase in the level of c-Myc activates the synthesis of a number of positive regulators of proliferation: cyclins $\mathrm{D}$ and $\mathrm{E}$, cyclin-dependent kinases CDK4 and 6, negative regulators of cell division, an inhibitor of cyclin-dependent kinase $1 \mathrm{~B}(\mathrm{CDKN} 1 \mathrm{~B})$, and retinoblastoma protein (RB1). C-Myc also suppresses the expression 
of cyclin-dependent kinase inhibitor 1A (CDKN1A) [30]. In addition, c-Myc activates the expression of the MINA53 gene (Myc-induced nuclear antigen 53), the product of which stimulates the rapid growth of human glioblastoma, leukemia, and stomach cancer cells [31-33]. MINA53 is able to participate in the activation of gene expression by regulating the methylation status of histone $\mathrm{H} 3 \mathrm{~K} 9 \mathrm{me} 3$ and it is also involved in the AP-1 signaling pathway, which is closely related to cell proliferation [31]. The expression of the ID1 gene is also regulated by c-Myc. In breast [34] and lung cancer cells [35], ID1 has been demonstrated to increase the rate of cell growth by regulating the expression of cyclins. Moreover, high levels of c-Myc stimulate the expression of thymidylate synthase (TS), inosine monophosphate dehydrogenase 2 (IMPDH2), and phosphoribosyl pyrophosphate synthetase 2 (PRPS2) by binding to their regulatory sequences. The expression levels of TS, IMPDH2, and PRPS2 positively correlate with the synthesis of nucleotides. In melanoma cells, it has been shown that cell proliferation is linked with the expression of TS, IMPDH2, and PRPS2 [36].

Healthy somatic cells have a limited number of divisions, while cancer cells are characterized by the ability to replicate endlessly. C-Myc has been shown to activate the expression of telomerase reverse transcriptase protein (TERT), which lengthens telomeres, allowing cells to divide an unlimited number of times [37] (Figure 1).

$\mathrm{C}-\mathrm{Myc}$ is also involved in the regulation of genomic stability, the disturbance of which is another characteristic feature of tumor development (Figure 1). MYC expression has been shown to be associated with the reduced expression of telomeric repeat-binding factor 2 (TRF2) $[38,39]$. Knockout of TRF2 genes leads to DNA damage on telomeres and chromosomal aberrations [40]. Overexpression of MYC can also cause an increase in the amount of reactive oxygen (ROS) in cells, which can damage DNA and increase the frequency of mutations [41]. This may happen due to the stimulation of expression of a number of mitochondrial genes and, in general, the process of mitochondrial biogenesis, as well as a negative effect on the level of the enzyme superoxide dismutase (SOD), which eliminates ROS [42,43]. At the same time, the high expression of MYC contributes to the survival of cells with multiple DNA damage by activating their repair systems. C-Myc has been shown to bind to the promoter region of the NBS1, KU70, RAD51, BRCA2, and RAD50 genes, which are involved in the repair of double-stranded breaks [44].

The resistance of cells to chemotherapeutic agents is a serious obstacle to the successful treatment of cancer patients. It has been found that an increased expression of the MYC gene is associated with the resistance of cells to a number of drugs. The effect of c-Myc on the expression of DNA repair factors is one of the possible reasons for the survivability of cells with a high level of this transcription factor during treatment with chemotherapeutic DNA-damaging drugs and short-wave radiation $[45,46]$. Thus, the suppression of MYC expression in lung cancer [47], melanoma [48], ovarian cancer [49], and bladder cancer cells [50] increases the sensitivity of the tumor to cisplatin. Additionally, in breast cancer cells resistant to the estrogen agonist tamoxifen, as well as to doxorubicin and paclitaxel, increased expression of the proto-oncogene MYC has been found [51].

Another important indicator of the development of cancer and a possible explanation for its resistance to chemotherapy is the evasion of cells from apoptosis. In this process, the role of c-Myc is ambiguous (Figure 1). C-Myc has been shown to regulate the expression of the prothymosin alpha (PTMA) gene, which is responsible for cell proliferation in many types of cancer. PTMA suppresses the expression of the BAX and BAD genes, which stimulate mitochondrial apoptosis. When MYC expression is suppressed or PTMA promoter mutations occur at the c-Myc binding site, the cells become sensitive to sorafenib [52]. Additionally, c-Myc suppresses the expression of a number of miRNAs, which control anti-apoptotic genes BCL-2 and MCL1 [30]. At the same time, the increased expression of the MYC gene in the cell activates the ARF-Mdm2-p53 tumor suppressor pathway, which leads to the activation of apoptosis and, as a result, the suppression of tumor growth [53]. In the case of faulty apoptosis mechanisms in the cell, for example, sustained mutations in p53 or ARF, overexpression of MDM2, and changes in the regulatory pathways of BCL-2 
and NF-kB [54,55], high expression of MYC does not lead to the death of tumor cells. It is also worth mentioning that a high level of MYC expression increases the resistance of myeloma cells to bortezomib by activating the pentose phosphate pathway. C-Myc has been shown to interact with the long non-coding RNA PDIA3P which enhances binding to the promoter of the G6PD gene involved in this metabolic pathway [56].

In addition to the pentose phosphate pathway, c-Myc also affects other cellular metabolic pathways (Figure 1). For tumor cells, the so-called Warburg effect is typical, which causes a suppression of pyruvate oxidation in mitochondria and an increase in the intensity of glycolysis and, consequently, this stimulates lactate production. This alteration can be explained by the necessity for rapid proliferation during oxygen deficiency and the possible adaptation of cells to cytotoxic agents, the effect of which is associated with oxygen metabolism [57]. C-Myc has been shown to regulate the expression of the glucose transporter gene GLUT1 by binding to the E-box sequence in its promoter. C-Myc is also able to activate the expression of monocarboxylate transporters (MCT1 and MCT2), which are responsible for the transport of the main product of oxygen-free metabolism, lactate [58]. C-Myc stimulates the expression of most glycolytic enzymes genes, including hexokinase II (HK2), pyruvate kinase m2 (PKM2), enolase 1 (ENO1), glyceraldehyde-3-phosphate dehydrogenase (GAPDH), and lactate dehydrogenase A (LDHA) [59,60]. Additionally, c-Myc plays a significant role in changing the metabolism of a number of amino acids: glutamine, proline, and branched-chain amino acids by activating glutaminase (GLS), P5C reductase (P5CR), and branched-chain aminotransferase (BCAT) expression [60,61]. Alterations in metabolism lead to the release of lactate, succinate, and glutamine by tumor cells, which contribute to the attraction of macrophages to the tumor and their polarization into the immunosuppressive phenotype M2 [62].

Active growth of solid tumors is impossible without interaction with the microenvironment, in particular, without the ability to avoid an immune response. In a series of experiments, it was shown that c-Myc regulates the expression of immune checkpoints in cells [63] (Figure 1). Suppression of c-Myc reduces the expression of the innate immunity regulator CD47 and the adaptive immunity checkpoint PD-L1, thus enhancing the antitumor immune response [64]. CD47 is known to interact with the signaling regulatory protein $\alpha$ SIRPa on the macrophage surface, preventing phagocytosis of the body's cells by macrophages. The PD-L1 ligand interacts with the PD-1 receptor on the surface of T-lymphocytes, suppressing their activity [65]. Moreover, some data suggest that Myc is able to down-regulate the expression of HLA class I in various cancers [66].

Tumor metastasis is another hallmark of cancer development. The cell undergoes an epithelial-mesenchymal transition in order for the cancer cells to spread and further consolidate in different parts of the body. Many experimental groups have shown a link between c-Myc regulation and cellular metastasis [67] (Figure 1). In clear cell renal cell carcinoma, PIM1-mediated phosphorylation of c-Myc activates transcription factors ZEB1, ZEB2, Snail1, Snail2, and Twist, which further trigger the epithelial-mesenchymal transition program and increase the likelihood of tumor metastasis [68]. Additionally, c-Myc promotes expression of miR-9-5p which controls the leukemia inhibitory factor receptor (LIFR) and suppressor of cytokine signaling 5 (SOCS5). LIFR inhibits metastasis through the Hippo/YAP pathway, and SOCS5 inhibits cell migration by inhibiting the JAK/STAT pathway $[30,69,70]$. A correlation between MYC expression and metastasis was also shown in non-small cell lung cancer [71], breast cancer [72], and gallbladder cancer [73].

For effective growth, cancer cells activate the mechanisms of angiogenesis (Figure 1). In the normal state, cells that do not receive enough oxygen can induce the expression of VEGF, which stimulates the development of new blood vessels. This mechanism is often used by cancer cells to vascularize the tumor. It was found that in leukemia cells, c-Myc binds to the VEGFA promoter sequence and thereby increases its expression [74]. The same mechanism of c-Myc's influence on VEGFC expression was found in cells of pancreatic neuroendocrine tumors [75]. The promoting effect of c-Myc on the expression of 
VEGF family factors was also shown in non-small cell lung cancer [71]. Moreover, c-Myc stimulates the expression of miRNAs that control the synthesis of a number of angiogenesis inhibitors: members of the TGF- $\beta$ signaling pathway (TGF beta receptor 2 (TGFBR2) and mothers against decapentaplegic homolog 4 (SMAD4)), thrombospondin 1 (THBS1), and connective tissue growth factor (CTGF) $[30,76,77]$.

As can be seen from the above data, c-Myc is involved in almost all mechanisms of oncogenesis of various types of tumors. At the same time, it should be noted that a small change in MYC expression (sometimes less than two-fold) is often enough to change the processes of oncogenesis [78-80]. For effective and long-term suppression of the expression of this proto-oncogene, it is necessary to know in detail the mechanisms that control the transcription of this gene, the stability of its mRNA and its translation, as well as the factors responsible for the stability of the Myc factor itself [25,46,81] (Figure 2).

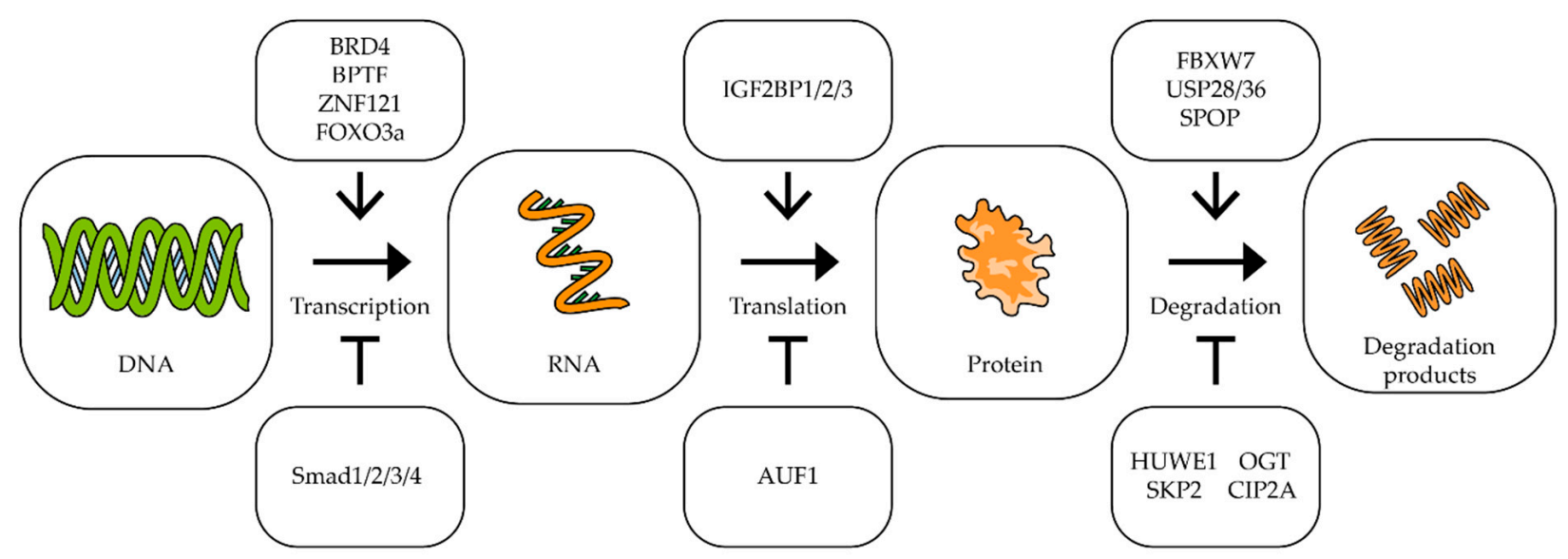

Figure 2. The impact of different factors on MYC transcription, translation and degradation. Schematic representation of influence of different factors on MYC transcription, translation, and c-Myc degradation. The upper/lower boxes indicate factors that activate/inhibit transcription, translation, or protein degradation (see text for description and references).

The bromodomain-containing protein 4 (BRD4) is a universal transcription regulator which also controls the transcription of the MYC proto-oncogene (Figure 2). Inhibition of BRD4 by thienotriazolodiazepine JQ1 in colorectal cancer cells reduces MYC expression and inhibits cell proliferation [82]. A similar effect is observed in retinoblastoma cells, where BRD4 inhibition induces cell cycle arrest and apoptosis [83]. In neuroblastoma, lung carcinoma, colon adenocarcinoma, and melanoma cells, dual PI3K/BRD4 inhibition by SF2523 contributes to a decrease in c-Myc levels and markedly inhibits the growth and metastasis of cancer cells $[84,85]$. Another bromodomain-containing protein, bromodomain PHD transcription factor (BPTF), can activate MYC expression. It has been shown that suppression of BPTF transcription and the use of BPTF inhibitors lead to a decrease in the expression of the MYC gene [86,87].

Proteins that interact directly with the c-Myc protein can also affect its gene transcription. In lung and breast cancer cells, a correlation was shown between the expression of the ZNF121 and MYC genes: during the siRNA-mediated knockdown of ZNF121, MYC expression decreased and, accordingly, when ZNF121 was overexpressed, MYC expression increased [88,89] (Figure 2). Among other things, suppression of the ZNF121 gene reduced the rate of proliferation in breast cancer cells [89].

It has been shown that in human fibroblasts, FOXO3a binds to the region in the c-MYC promoter, and this interaction activates the transcription of the c-MYC gene [90]. On the other hand, the interaction of the promoter of this gene with the proteins of the SMAD family leads to the suppression of expression of the MYC gene [91,92]. 
IGF2BP1/2/3 (mRNA-binding proteins of insulin-like growth factor 2) are able to bind to many mRNAs, including the c-Myc mRNA, recognizing the GG(m6A)C sequence, and by this binding, it stabilizes the mRNA. It has been shown that suppression of IGF2BP1/2/3 expression in cervical cancer and liver cancer cells leads to a decrease in the amount of c-Myc protein, as well as to a decrease in the rate of proliferation [93] (Figure 2).

AU-rich element RNA-binding protein 1 (AUF1) binds to AU-rich mRNA regions and triggers the mRNA degradation process. It has been shown that the suppression of AUF1 does not lead to a change in the level of MYC mRNA, but reduces the amount of c-Myc protein in cells, which suggests that AUF1 may affect the translation of this mRNA (Figure 2). In addition, suppression of AUF1 led to a decrease in the rate of proliferation in leukemia, colon cancer, and cervical cancer cells [94,95].

C-Myc is a short-lived protein, so the mechanisms responsible for its stability and degradation play an important role in tumor development. In tumors with a high level of c-Myc, improper functioning of the mechanisms of its ubiquitination can be observed. It is important to note that different types of ubiquitin ligases have different effects on the stability of this transcription factor (Figure 2). For example, ubiquitin ligase FBXW7 and E3 ubiquitin ligase adapter SPOP promote the degradation of c-Myc [96,97], while ubiquitin ligases SKP2 and HUWE1, on the contrary, improve the stability of this protein. In multiple myeloma, suppression of HUWE1 expression leads to a decrease in c-Myc levels and inhibition of tumor growth [98]. Enzymes deubiquitinating c-Myc have also been shown to affect its stability. Thus, suppression of USP28 and USP36 reduces the c-Myc level and suppresses cell proliferation $[99,100]$. Glycosyltransferase OGT has been shown to enhance cell proliferation by stabilizing the c-Myc protein by combining it with $\beta-\mathrm{N}$-acetylglucosamine [101]. Increased OGT expression was found in many tumors, including prostate [102], breast [103], lung, and colon cancers [104]. Lowering the level of OGT mRNA leads to a decrease in c-Myc protein in prostate cancer cells [102]. Another protein, cancer inhibitor of protein phosphatase 2A (CIP2A), has increased expression levels in colorectal cancer [105], stomach cancer [106], prostate cancer [107], and multiple myeloma [108]. CIP2A has been shown to prevent the degradation of the c-Myc protein by inhibiting the activity of phosphatase PP2A. Phosphatase PP2A dephosphorylates c-Myc at serine 62, which is necessary for ubiquitination by ubiquitin ligase FBXW7 and initiation of degradation [109] (Figure 2).

A more detailed understanding of the regulation of MYC expression in cancer cells opens up new targets for drug discovery and new approaches in the treatment of cancer. Recently, many groups of scientists have confirmed that non-coding RNAs play an important role in regulating cellular processes, blocking or activating the transcription and translation of this gene, or interacting with the c-Myc protein directly. In tumor cells, shifts in the expression of many non-coding RNAs may be involved in tumor development $[110,111]$. It is important that the expression of some RNAs is specific to certain types of cancer. This makes non-coding RNAs a convenient target for suppressing tumor development with minimal possible impact on healthy cells [112]. Among other things, non-coding RNAs have shown themselves to be a promising marker for the diagnosis of oncogenic diseases [113]. This diagnostic method is convenient, as non-coding RNAs can be easily detected in the cells and biological fluids of the patient. For example, the detection of lncRNA PCA3 in urine is widely used as a marker of prostate cancer [114]. Similarly, the lncRNA AA174084 in gastric juice is a potential biomarker for the early diagnosis of gastric cancer [115].

In this review, we will examine in more detail the effect of miRNAs, long non-coding RNAs, and circular RNAs on the expression of the MYC proto-oncogene in various types of cancer.

\section{2. miRNAs}

MicroRNAs (miRNAs) are a class of small, endogenous, single-stranded non-coding RNA molecules. They act as a sequence-specific tool that is widely used in nature to 
regulate gene expression. At the moment, several dozens of miRNA variants that affect the expression of the MYC gene have been analyzed. Most of these miRNAs bind directly to the mRNA of the MYC gene [30]. Others affect its level by regulating genes that control the stability of the c-Myc protein. For example, miR-375-3p suppresses the expression of the CIP2A gene, the product of which is involved in the stabilization of c-Myc due to the phosphorylation of Ser62 [116]. Another example in mouse hepatoma cells is miR-24 regulating the OGT gene that increases the stability of the c-Myc protein by combining with $\beta$-N-acetylglucosamine [117].

As described above, high expression of the MYC gene is characteristic of many types of cancers. In this regard, it is not surprising that in tumors, the levels of most miRNAs that control the expression of the MYC gene are often reduced. The possibility of using miRNA complementary to the MYC gene sequence is being considered as a targeted therapy for cancer $[118,119]$. The use of miRNA leads to a reduced survival rate of tumor cells of different types of cancer, suppression of their reproduction, and migration [120-123]. It is important to note that for some miRNAs that bind to the mRNA of the MYC gene, a protective effect for tumor cells was also revealed. Thus, it was shown that Hodgkin's lymphoma cells can have a high level of miR-24-3p, which limits the expression of CDKN1B/P27kip1 and MYC genes and also protects cells from apoptosis [124]. On the other hand, a reduced level of miR-24-3p is observed in breast cancer and nasopharyngeal carcinoma cells, increasing the metastatic potential of tumor cells $[125,126]$. In another study, it was found that hepatocellular carcinoma cells with a lower level of miR-17-5p have greater metastatic activity, but a lower survival rate compared to cells of this tumor with more highly expressed miRNA [127]. Several studies have shown that the expression of many miRNAs differs significantly both in normal human tissues and in different types of tumors $[128,129]$. Thus, to study the possibility of using miRNA in therapy, it is necessary to take into account which RNAs control c-Myc levels in different types of cancer and their mechanisms.

\section{1. miRNAs Controlling the Expression of the MYC Gene in Various Types of Cancer}

For various types of cancer, the role of miRNAs of the let-7 family in regulating the expression of the MYC gene has been described (Table 1; Figure 3). A decreased level of these miRNAs in tumor cells is associated with a negative prognosis in patients with acute myeloid leukemia [130], breast cancer [131], stomach cancer [132], liver cancer [133], and neuroblastoma [134]. The expression level of let-7 is inversely correlated with the metastatic activity of prostate cancer [135]. Overexpression of miRNA of the let-7 family leads to the suppression of the proliferation of cells of breast [136-138], liver [139,140], lung [141], and colon cancers [142,143], and B-cell lymphomas [144-146]. The cancer-fighting qualities of the let-7 miRNA family are also explained by their effect on the expression of other proto-oncogenes: K-RAS, HMGA2, and cyclin D1 and D2 [147]. However, in some cases, members of let-7 miRNA family can stimulate the development of a tumor, for example, a high level of let-7g stimulates the progression of osteosarcoma [148].

Table 1. miRNAs that control the expression of the MYC gene in tumors of various human organs.

\begin{tabular}{ccccc}
\hline Cancer & MiRNA & Alteration in Cancer & $\begin{array}{c}\text { Mechanistically } \\
\text { \{Association with the Altered } \\
\text { Level of this RNA in Tumor Cells\} }\end{array}$ & References \\
\hline $\begin{array}{c}\text { Acute myeloid } \\
\text { leukemia }\end{array}$ & let-7 & Down-regulated & [Poor prognosis\} \\
\hline Bladder cancer & miR-155 & Down-regulated & Inhibits cancer cell proliferation & {$[149]$} \\
\hline
\end{tabular}


Table 1. Cont.

\begin{tabular}{|c|c|c|c|c|}
\hline Cancer & MiRNA & Alteration in Cancer & $\begin{array}{c}\text { Mechanistically } \\
\text { \{Association with the Altered } \\
\text { Level of this RNA in Tumor Cells\} }\end{array}$ & References \\
\hline \multirow{3}{*}{ Burkitt lymphoma } & $\begin{array}{l}\text { let-7a } \\
\text { let-7b } \\
\text { miR-98 }\end{array}$ & Down-regulated & Reverses MYC-induced growth & [120] \\
\hline & $\begin{array}{c}\text { miR-34b-5p } \\
\text { let-7c }\end{array}$ & Down-regulated & G1 arrest & [151] \\
\hline & $\begin{array}{l}\text { let-7-5p } \\
\text { miR-132-5p } \\
\text { miR-125b-1 } \\
\text { miR-154 }\end{array}$ & Down-regulated & Inhibits cancer cell proliferation & [121] \\
\hline \multirow{6}{*}{ Breast cancer } & $\begin{array}{l}\operatorname{miR}-17-5 p \\
\operatorname{miR}-20 a-5 p\end{array}$ & Down-regulated & Inhibits cancer cell proliferation & [152] \\
\hline & miR-34b-3p & Down-regulated & $\begin{array}{c}\text { \{Associated with metastasis } \\
\text { development }\end{array}$ & [153] \\
\hline & miR-145-5p & Down-regulated & \{Poor prognosis\} & [154] \\
\hline & $\begin{array}{l}\text { miR-21-5p } \\
\text { miR-98-5p } \\
\quad \text { let-7 }\end{array}$ & Down-regulated & Suppresses cancer cell growth & [136] \\
\hline & let-7 & Down-regulated & \{Poor prognosis\} & [131] \\
\hline & let-7 & Down-regulated & Inhibits cancer cells proliferation & {$[137,138]$} \\
\hline \multirow{4}{*}{ Colon cancer } & miR-34b-3p & Down-regulated & $\begin{array}{c}\text { \{Associated with metastasis } \\
\text { development }\}\end{array}$ & [153] \\
\hline & miR-145-5p & Down-regulated & $\{$ Poor prognosis $\}$ & [154] \\
\hline & let-7 & Down-regulated & Suppresses cancer cell growth & {$[142,143]$} \\
\hline & $\begin{array}{l}\operatorname{miR}-33 b \\
\operatorname{miR}-93\end{array}$ & Down-regulated & $\begin{array}{l}\text { Inhibited cell proliferation, } \\
\text { migration, and invasion }\end{array}$ & [155] \\
\hline \multirow{4}{*}{ Colorectal cancer } & $\mathrm{miR}-320 \mathrm{~b}$ & Down-regulated & Inhibits cancer cell proliferation & [156] \\
\hline & miR-182-5p & Down-regulated & Inhibits cancer cell proliferation & [156] \\
\hline & miR-182a-5p & Down-regulated & Inhibits cancer cell proliferation & [157] \\
\hline & miR-200b-3p & Down-regulated & Inhibits cancer cell proliferation & [158] \\
\hline $\begin{array}{l}\text { Diffuse large B-cell } \\
\text { lymphoma }\end{array}$ & miR-34b-5p & Down-regulated & Inhibits cancer cell proliferation & [159] \\
\hline \multirow{7}{*}{ Gastric cancer } & $\operatorname{miR}-212-3 p$ & Down-regulated & Inhibits cancer cell proliferation & [160] \\
\hline & $\operatorname{miR}-429$ & Down-regulated & $\begin{array}{l}\text { Inhibits cancer cell viability, } \\
\text { proliferation, and attachment }\end{array}$ & [123] \\
\hline & let-7 & Down-regulated & $\{$ Poor prognosis $\}$ & [132] \\
\hline & $\operatorname{miR}-494-3 p$ & Down-regulated & Inhibits cancer cells proliferation & [145] \\
\hline & miR-155-5p & Down-regulated & $\begin{array}{l}\text { Inhibits cancer cell growth and } \\
\text { invasion }\end{array}$ & [144] \\
\hline & miR-33b-5p & Down-regulated & $\begin{array}{l}\text { Inhibited cell proliferation, } \\
\text { migration, and invasion }\end{array}$ & [161] \\
\hline & $\operatorname{miR}-25-5 p$ & Up-regulated & Inhibits cancer cell apoptosis & [162] \\
\hline
\end{tabular}


Table 1. Cont.

\begin{tabular}{|c|c|c|c|c|}
\hline Cancer & MiRNA & Alteration in Cancer & $\begin{array}{c}\text { Mechanistically } \\
\text { \{Association with the Altered } \\
\text { Level of this RNA in Tumor Cells\} }\end{array}$ & References \\
\hline & $\operatorname{miR}-34 a$ & Down-regulated & $\begin{array}{l}\text { Inhibits cancer cell growth and } \\
\text { invasion }\end{array}$ & [163] \\
\hline & miR-561-3p & Down-regulated & $\begin{array}{l}\text { Inhibits cancer cell growth and } \\
\text { invasion }\end{array}$ & [164] \\
\hline & miR-590-3p & Down-regulated & Inhibits cancer cell proliferation & [165] \\
\hline & miR-150-5p & Down-regulated & $\begin{array}{l}\text { Inhibits cell proliferation and } \\
\text { migration }\end{array}$ & [166] \\
\hline & $\begin{array}{l}\text { miR-145 } \\
\text { miR-1304 }\end{array}$ & Down-regulated & Inhibits cell proliferation & [167] \\
\hline & $\operatorname{miR}-449 c-5 p$ & Down-regulated & $\begin{array}{l}\text { Inhibits cell proliferation and } \\
\text { migration }\end{array}$ & [168] \\
\hline & miR-125 & Down-regulated & Inhibits cell proliferation & [169] \\
\hline \multirow{3}{*}{ Glioma } & miR-29b-1 & Down-regulated & Inhibits cancer cell proliferation & [170] \\
\hline & $\operatorname{miR}-33 b-5 p$ & Down-regulated & Inhibits cancer cell proliferation & [171] \\
\hline & miR-135a-5p & Down-regulated & Inhibits cancer cell proliferation & [172] \\
\hline \multirow{2}{*}{$\begin{array}{l}\text { Head and neck } \\
\text { carcinoma }\end{array}$} & $\operatorname{miR}-34 b-3 p$ & Down-regulated & $\begin{array}{c}\text { Associated with metastasis } \\
\text { development }\}\end{array}$ & [153] \\
\hline & miR-34a-5p & Down-regulated & $\begin{array}{l}\text { Attenuates tumor growth and } \\
\text { metastasis }\end{array}$ & [173] \\
\hline Hodgkin Lymphoma & miR-24-3p & Up-regulated & Protects cancer cells from apoptosis & [124] \\
\hline \multirow{4}{*}{ Liver cancer } & let-7g & Down-regulated & $\begin{array}{c}\text { Inhibits proliferation of } \\
\text { hepatocellular carcinoma cells }\end{array}$ & [139] \\
\hline & let-7 & Down-regulated & $\{$ Poor prognosis\} & [133] \\
\hline & $\begin{array}{l}\operatorname{miR}-148 a-5 p \\
\operatorname{miR}-363-3 p\end{array}$ & Down-regulated & G1 arrest & [174] \\
\hline & miR-744-5p & Down-regulated & Inhibits cancer cell proliferation & [175] \\
\hline \multirow{7}{*}{ Liver cancer } & miR-599 & Down-regulated & $\begin{array}{l}\text { Inhibits cancer cell proliferation, } \\
\text { migration, and invasion }\end{array}$ & [176] \\
\hline & miR-320a & Down-regulated & $\begin{array}{l}\text { Inhibits tumor proliferation and } \\
\text { invasion }\end{array}$ & [177] \\
\hline & let-7 & Down-regulated & Inhibits cancer cell proliferation & [140] \\
\hline & $\begin{array}{l}\operatorname{miR}-9 \\
\text { miR-185-5p }\end{array}$ & Up-regulated & $\begin{array}{l}\text { Inhibits cancer cell proliferation and } \\
\text { survival }\end{array}$ & [178] \\
\hline & $\operatorname{miR}-17-5 p$ & Down-regulated & $\begin{array}{l}\text { Represses invasiveness and } \\
\text { metastasis, increases survival }\end{array}$ & [127] \\
\hline & miR-122-5p & Down-regulated & Inhibits cancer cell proliferation & [179] \\
\hline & miR-526b & Down-regulated & Inhibits cancer cell proliferation & [180] \\
\hline
\end{tabular}


Table 1. Cont.

\begin{tabular}{|c|c|c|c|c|}
\hline Cancer & MiRNA & Alteration in Cancer & $\begin{array}{c}\text { Mechanistically } \\
\text { \{Association with the Altered } \\
\text { Level of this RNA in Tumor Cells\} }\end{array}$ & References \\
\hline \multirow{10}{*}{ Lung cancer } & miR-34b-3p & Down-regulated & $\begin{array}{c}\text { \{Associated with metastasis } \\
\text { development }\end{array}$ & [153] \\
\hline & let-7a-5p & Down-regulated & Inhibits the growth of lung cancer & [141] \\
\hline & miR-145-5p & Down-regulated & Inhibits cancer cell proliferation & [181] \\
\hline & miR-487b-3p & Down-regulated & $\begin{array}{l}\text { Inhibits cancer cell growth and } \\
\text { invasion }\end{array}$ & [182] \\
\hline & $\operatorname{miR}-449 c-5 p$ & Down-regulated & Inhibits cancer cell proliferation & [183] \\
\hline & $\operatorname{miR}-451 \mathrm{a}$ & Down-regulated & $\begin{array}{l}\text { Reverses EMT to } \\
\text { mesenchymal-epithelial transition }\end{array}$ & [146] \\
\hline & miR-34a-5p & Down-regulated & Inhibits cancer cell proliferation & [184] \\
\hline & miR-199a-5p & Down-regulated & Inhibits cancer cell proliferation & [185] \\
\hline & miR-4302 & Down-regulated & $\begin{array}{l}\text { Inhibits cancer cell proliferation and } \\
\text { invasion }\end{array}$ & [88] \\
\hline & miR-586-5p & Up-regulated & Enhances cancer cell proliferation & [59] \\
\hline Medulloblastoma & miR-33b-5p & Down-regulated & Inhibits cancer cell proliferation & [186] \\
\hline Melanomas & $\operatorname{miR}-34 b-3 p$ & Down-regulated & $\begin{array}{c}\text { \{Associated with metastasis } \\
\text { development }\end{array}$ & [153] \\
\hline \multirow{2}{*}{ Myeloma } & miR-126-5p & Down-regulated & Inhibits cancer cell proliferation & [187] \\
\hline & miR-29a-3p & Down-regulated & Inhibits cancer cell viability & \\
\hline \multirow{2}{*}{$\begin{array}{l}\text { Nasopharyngeal } \\
\text { carcinoma }\end{array}$} & miR-184 & Down-regulated & Blocks cell growth and survival & [188] \\
\hline & $\operatorname{miR}-24-3 p$ & Down-regulated & Suppresses metastasis & [125] \\
\hline Neuroblastoma & let-7 & Down-regulated & $\{$ Worse overall survival $\}$ & [134] \\
\hline \multirow{2}{*}{$\begin{array}{l}\text { Oral squamous cell } \\
\text { carcinoma }\end{array}$} & miR-145-5p & Down-regulated & Inhibits cancer cell proliferation & {$[189,190]$} \\
\hline & miR-526b-5p & Down-regulated & Inhibits cancer cell proliferation & [191] \\
\hline \multirow{8}{*}{ Prostate cancer } & $\operatorname{miR}-34 c-5 p$ & Down-regulated & Inhibits cancer cell proliferation & [192] \\
\hline & miR-145-5p & Down-regulated & Inhibits cancer cell proliferation & [193] \\
\hline & let-7 & Down-regulated & Higher in non-metastatic tumors & [135] \\
\hline & $\begin{array}{l}\operatorname{miR}-34 \\
\text { let-7 }\end{array}$ & Down-regulated & $\{$ Poor prognosis\} & [194] \\
\hline & miR-3667-3p & Down-regulated & Inhibits cancer cell proliferation & [195] \\
\hline & $\operatorname{miR}-449 a$ & Down-regulated & Enhances cancer cell radiosensitivity & [196] \\
\hline & miR-33b & Down-regulated & Inhibits cancer cell proliferation & [197] \\
\hline & miR-184 & Down-regulated & Inhibits cancer cell proliferation & [198] \\
\hline Renal cell carcinoma & $\operatorname{miR}-34 a-5 p$ & Down-regulated & $\begin{array}{l}\text { Suppresses malignant } \\
\text { transformation }\end{array}$ & [199] \\
\hline $\begin{array}{l}\text { T-cell acute } \\
\text { lymphoblastic } \\
\text { leukemia }\end{array}$ & $\begin{array}{l}\operatorname{miR}-451 \mathrm{a} \\
\mathrm{miR}-709\end{array}$ & Down-regulated & Inhibits cancer cell proliferation & [200] \\
\hline \multirow{2}{*}{ Thyroid cancer } & let-7f-5p & Down-regulated & Inhibits cancer cell proliferation & [201] \\
\hline & miR-33a-5p & Down-regulated & Inhibits cancer cell proliferation & [202] \\
\hline
\end{tabular}

The expression, stability, and activity of miRNAs of the let-7 family are regulated by various factors. The most interesting is the regulatory loop with the MYC gene. An 
increase in the level of c-Myc boosts the expression of the LIN28A and LIN28B genes, whose products trigger the degradation of the let-7 family miRNAs [203] (Figure 3). Thus, artificially expressed miRNAs can lead to stimulation of the endogenous production of let-7 by suppressing the MYC expression. It has also been shown that the level of miRNAs of this family increases in breast cancer cells in response to estrogen. It is assumed that this effect serves to limit the stimulation of MYC expression by the same hormone [136]. Another way to regulate miRNA activity is to inactivate them by binding to long non-coding RNAs, so-called competing endogenous RNAs (ceRNA). Thus, ceRNA H19 couples with let-7b in breast cancer cells, activating epithelial-mesenchymal transition processes [137], and CCAT1 RNA binds miRNA of the let-7 family in hepatocellular carcinoma cells, stimulating their proliferation and migration [140]. The role of ceRNA will be described more precisely in the next section.

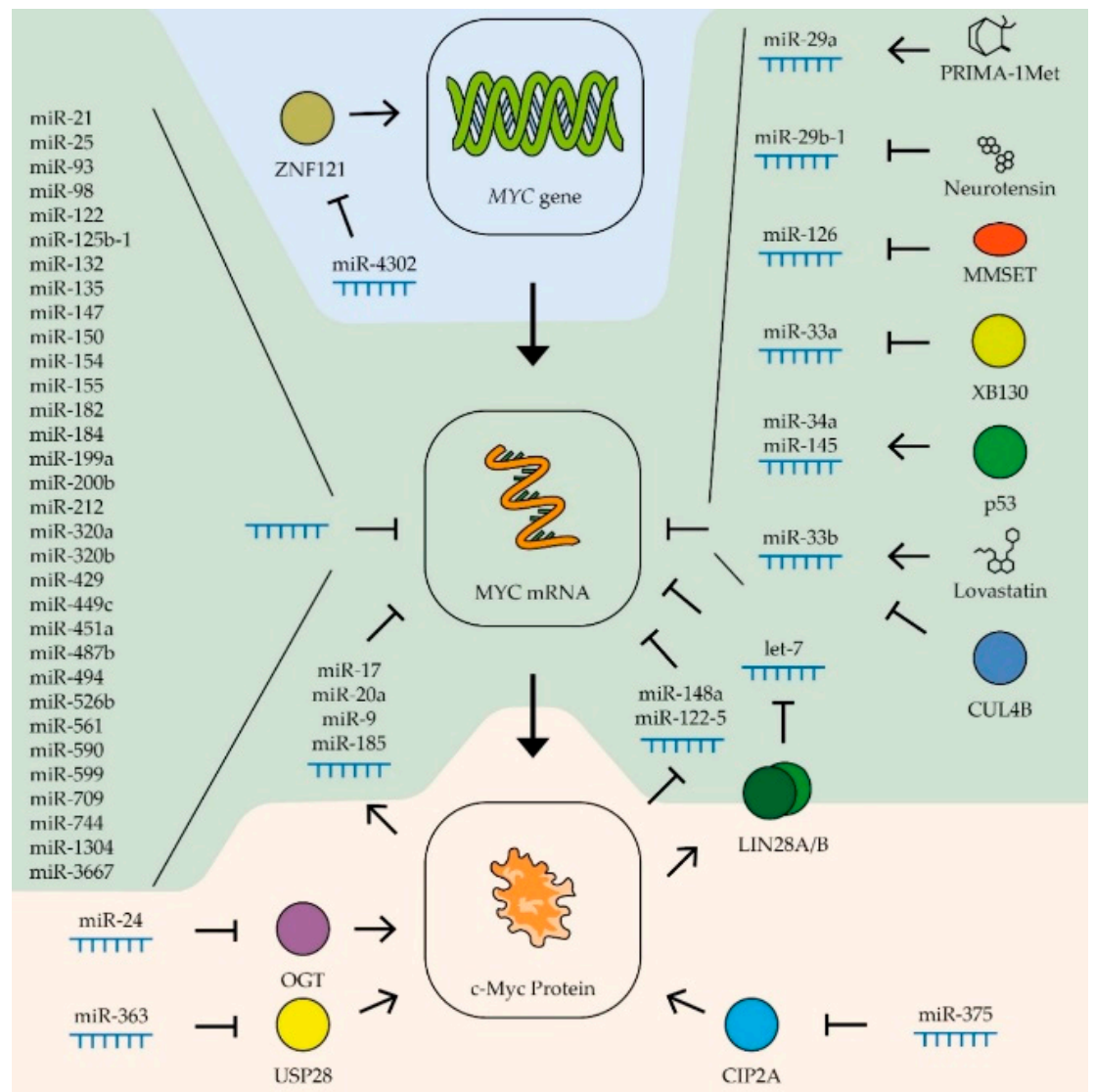

Figure 3. Control of MYC expression by miRNAs. Schematic representation of miRNAs' influence on MYC gene transcription (blue zone), MYC mRNA (green zone), and c-Myc protein stability (yellow zone). Colored circles indicate the proteins included in the pathway. (See text for description and references).

MiR-34 is another miRNA family that controls the expression of the MYC gene in various tumor types (Table 1). Reduced expression of miRNAs of this family in tumor cells is associated with increased metastatic activity in patients with prostate cancer [194], as well as breast, lung, and colon cancers, melanoma, and head and neck tumors [153]. An artificial increase in the expression of these miRNAs leads to suppression of the proliferation of gastric [163] and prostate [192] cancers, head and neck tumors [173], and B-cell lymphoma [204] and also suppresses the tumor transformation of kidney epithelial cells [199]. It has been shown that the tissue-specific factor gastrokine-1 stimulates the expression of miR-34a in gastric cancer cells, suppressing the expression of proto-oncogenes MYC (Figure 3) and RhoA, which leads to a decrease in the ability of cells to migrate and 
invade [163]. Stimulation of miRNA miR-34a expression occurs when the tumor repressor p53 is activated [184]. Activation of p53 also leads to an increase in the expression of another miRNA, miR-145-5p, which also controls the expression of the MYC gene [154] (Figure 3). These data demonstrate that the stimulation of the expression of miR-34a and miR-145-5p is significant in the antitumor activity of p53 in various types of cancer. Overexpression of miR-145-5p considerably suppresses the proliferation of breast and colon cancer cells [154], lung cancer cells [181], prostate cancer cells [193], gastric cancer [167], and oral squamous carcinoma cells [189].

\section{2. miRNAs That Control the Expression of the MYC Gene in Breast Cancer Cells}

The influence of miRNAs of other families on the expression of the MYC gene has been shown in certain types of tumors. Thus, for breast cancer, in addition to the previously described let-7, miR-34, miR-145-5p, and miR-24-3p, a contribution to the regulation of MYC expression was shown for several other miRNAs with more distinct tissue specificity (Table 1). For example, in addition to let-7, two other miRNAs that control the expression of the MYC gene are involved in coordinating the response to estrogen in breast cancer cells: miR-21-5p and miR-98-5p [136]. The expression of miRNAs miR-17-5p and miR20a-5p that suppress the MYC gene is activated in breast cancer cells by the c-Myc factor, which demonstrates their participation in the negative regulation of the expression of this factor [152] (Figure 3).

\section{3. miRNAs That Control the Expression of the MYC Gene in the Cells of Tumors of the Digestive System}

For gastric cancer, many miRNAs have been found that control the expression of the MYC gene (Table 1). In addition to the previously described let-7, miR-145, and miR34 , the expression of this proto-oncogene is controlled by miRNAs miR-212-3p, miR-429, miR-125, miR-494-3p, miR-155-5p, miR-33b-5p, miR-25-5p, miR-150-5p, miR-1304, miR590-3p, miR-449c-5p, and miR-561-3p [115,122,152,160-162,164-166,168,169]. In tumor cells, the levels of most of these miRNAs, with the exception of miR-25-5p, are lower than in normal tissue, and artificially increasing their expression leads to suppression of tumor cell proliferation and their ability to invade neighboring tissues. On the contrary, miR-25-5p RNA is hyperexpressed in gastric adenocarcinoma cells compared to normal tissue. Increased expression of this RNA is associated with a higher survival rate of cancer cells [162] (Figure 3).

MiR-33b and miR-93 have been shown to reduce MYC expression in bowel cancer cells (Table 1). Suppression of the activity of these miRNAs leads to an increase in the ability of the tumor to grow and form metastases [155]. Four other miRNAs that control MYC expression were also found in cells of this type of cancer: miR-200b-3p, miR-182-5p, miR182a-5p, and miR-320b (Figure 3). The expression of all these RNAs is reduced in tumor cells, and their overexpression suppresses the proliferation of rectal cancer cells [156-158].

Regulation of MYC gene expression by miRNAs of the miR-320 family has been shown for liver cancer cells. Increased expression of miR-320a inhibits the ability of hepatocellular carcinoma cells to grow invasively [177]. MiRNA let-7, miR-148a-5p, miR363-3p, miR-744-5p, miR-599, miR-9, miR-185-5p, miR-526b, miR-17-5p, and miR-122-5 are also involved in regulating the expression of the MYC proto-oncogene in liver cancer cells (Table 1). Constitutive overexpression of these miRNA suppresses the proliferation of cancer cells and their ability to invade $[127,133,140,174-176,178-180]$. For three of these RNAs, miR-148a-5p, miR-363-3p, and miR-122-5, negative feedback was shown with the expression of the MYC gene (Figure 3). Thus, c-Myc has been shown to directly inhibit the activity of these RNA promoters in liver cancer cells $[174,179]$. It is worth noting that unlike miR-148a-5p and miR-122-5, which directly interacts with the mRNA of the MYC gene, miR-363-3p suppresses the expression of ubiquitin-specific protease 28 , that stabilizes the c-Myc protein [174]. For miRNAs miR-17-5p, miR-9, and miR-185-5p, positive feedback was shown with MYC gene expression; transcription factor c-Myc stimulates transcription of these miRNAs in liver cancer cells $[133,178]$ (Figure 3). Interestingly, in 
contrast to miR-17-5p, the expression levels of miR-9 and miR-185-5p in tumor cells are higher than in normal tissues [178]. A high level of miRNA suppressing MYC expression can be combined with a high level of transcription of this proto-oncogene in tumor cells due to ceRNA, which binds and inactivates certain miRNAs. Therefore, earlier in the liver cells, an increased level of RNA CCAT1, which binds to miRNA of the let-7 family, was detected [140]. A specific ceRNA, Linc00176, was also found for miRNAs miR-9 and miR-185-5p. Its enhanced expression level disrupts the reverse regulation of MYC gene expression in hepatocellular carcinoma cells, creating conditions for consistently high MYC expression. For this reason, this ceRNA can be considered as an important target for the development of therapy [178].

\section{4. miRNAs That Control MYC Gene Expression in Lung Cancer Cells}

An intriguing study was devoted to the negative effect of cigarette smoke on the expression of miR-487b-3p in lung cancer cells. This RNA suppresses the expression of a number of proto-oncogenes, including MYC, and its constitutive expression leads to a decrease in the proliferation and ability of lung cancer cells to invade [182]. In addition to the RNA families let-7, miR-34, and miR-145 mentioned in other sections, the expression of the MYC gene in lung cancer cells is also controlled by miR-199a-5p, miR-449c-5p, and miR-451a (Table 1). As expected, the expression levels of these RNAs in tumor cells are lower than in normal tissue, and a constitutive increase in their expression level leads to impaired proliferation and mesenchymal-epithelial transition of tumor cells [146,183,185]. Some miRNAs affect the expression level of the MYC gene by affecting the mRNA of factors that regulate the transcription of this oncogene. Thus, miR-4302 interacts with ZNF121 mRNA, lowering the level of the factor that activates the transcription of the MYC gene. The binding of this RNA by circRNA-103809 in lung cancer cells leads to an increase in the ability of the tumor for invasive growth [88] (Figure 3).

\section{5. miRNAs That Control the Expression of the MYC Gene in Prostate Cancer Cells}

In addition to the RNA families let-7, miR-34, and miR-145 mentioned before, the expression of the MYC gene in prostate cancer cells is controlled by miR-3667-3p and miR-33b (Table 1). The expression of the latter in tumor cells is suppressed by the cullin-4B protein, the mutation of which is characteristic of different cancer types [195,197] (Figure 3). Recently, it has also been found that the expression of miR-449a in prostate cancer cells increases in response to ionizing radiation at a dose of 4-8 Gy and, by suppressing the expression of the MYC gene, increases the sensitivity of these cells to radiation. Increasing the expression of such RNAs can be used to enhance the effectiveness of tumor radiotherapy [196]. In prostate cancer cells, dysregulation of MYC expression was also found due to an increased level of ceRNA MYU, which is able to bind to miRNA miR-184 [198] (Figure 3). The same miRNA is involved in the regulation of c-Myc levels in nasopharyngeal cancer cells. MiR-184 has been shown to inhibit MYC expression and tumor cell proliferation in response to increased levels of the tumor suppressor PDCD4 [188].

\section{6. miRNAs That Control MYC Gene Expression in Blood Cancer Cells}

Besides the RNA families let-7 and miR-34, the expression of the MYC gene in Burkitt lymphoma cells is controlled by miR-132-5p, miR-125b-1, miR-154, and mir-98 (Table 1). The expression of these miRNAs is suppressed in tumor cells, and their constitutive expression inhibits the proliferation of lymphoma cells [120,121]. In other types of blood cancers, specific miRNAs involved in the regulation of MYC gene expression have also been discovered. For example, a low level of the miRNAs miR-451a and miR-709 has been shown to have an important role in the development of acute T-cell leukemia [200]. Suppression of the expression of two other miRNAs that control the level of the MYC protooncogene, miR-126-5p and miR-29a-3p, is necessary for the survival and reproduction of myeloma cells $[187,205]$ (Table 1). The expression of miR-126-5p in myeloma cells is suppressed by histone methyltransferase MMSET, the level of which can be increased in 
tumor cells as a result of a translocation between chromosomes 4 and 14 [187] (Figure 3). Additionally, in acute myeloma cells, it has been revealed that the lncRNA CCAT1 binds to miR-155, which leads to an increase in the level of MYC expression [149]. The use of these miRNAs and their analogs for tumor therapy is not yet common practice, but the level of expression of some miRNAs can be regulated using low-molecular-weight substances. For example, PRIMA-1Met causes an increase in the expression of miR-29a-3p in multiple myeloma cells, which leads to a decrease in the level of c-Myc and reduces the survival rate of tumor cells [205] (Figure 3).

\section{7. miRNAs That Control the Expression of the MYC Gene in the Cells of Tumors of the Nervous System}

In glioma cells, the level of c-Myc is controlled by miR-29b-1, the expression of which is suppressed by neurotensin (Figure 3). Decreased expression of the neurotensin receptor restored the level of this miRNA and suppressed the proliferation of tumor cells [170]. In patients with glioma, there is an inverse correlation between survivability and the expression of another RNA, miR-135a-5p, which suppresses the expression of the MYC gene [172] (Table 1). In the cancers of the nervous system, glioma and medulloblastoma, miRNA miR-33b-5p disturbs the regulation of MYC expression [171,186]. When searching for small molecules as anti-cancer drugs, it was found that lovastatin can increase the expression of miR-33b-5p in medulloblastoma cells [186] (Figure 3).

\section{8. miRNAs That Control the Expression of the MYC Gene in Thyroid Tumor Cells}

Another RNA of the miR-33a family, miR-33a-5p, is involved in the regulation of MYC expression in thyroid cancer. Suppression of the expression of this miRNA may be associated with the activity of the XB130 protein, and inhibition of this factor led to stunted growth of tumor cells [202] (Figure 3).

\section{IncRNA}

Long non-coding RNAs can control the level of active factor c-Myc at different levels: (1) at the level of transcription, by attracting transcription factors to the MYC gene regulatory sequence; (2) at the level of mRNA stability of this gene, by recruiting specific miRNA; (3) at the level of protein stability and by regulating the efficiency of c-Myc binding to DNA regulatory sequences (Figure 4). Several lncRNAs have been shown to be involved in regulatory loops associated with MYC gene expression in different tumor types. For example, the lncRNA c-Myc inhibitory factor (MIF), found in B-cell lymphoma cells, is synthesized with the participation of c-Myc factor, but by binding miR-586 it activates the expression of ubiquitin ligase E3, which promotes the degradation of c-Myc factor. Increased expression of MIF lncRNA suppresses the proliferation of lung cancer and cervical cancer cells [59]. Another lncRNA involved in a regulatory loop with the MYC gene is the ovarian adenocarcinoma-amplified lncRNA OVAAL. This lncRNA stimulates the activity of the MAPK cascade, including ERK kinase, which stabilizes c-Myc factor by phosphorylating it at serine 62. OVAAL RNA expression, in turn, is stimulated by c-Myc factor. Increased levels of this lncRNA promote the survival and proliferation of melanoma and colon cancer cells [206]. The expression of an antisense lncRNA of glutaminase (GLS-AS) can be suppressed in some tumor types, and this correlates with high levels of glutaminase. This enzyme can interact with c-Myc, increasing its stability. Interestingly, c-Myc factor itself suppresses GLS-AS expression [207] (Figure 4). 


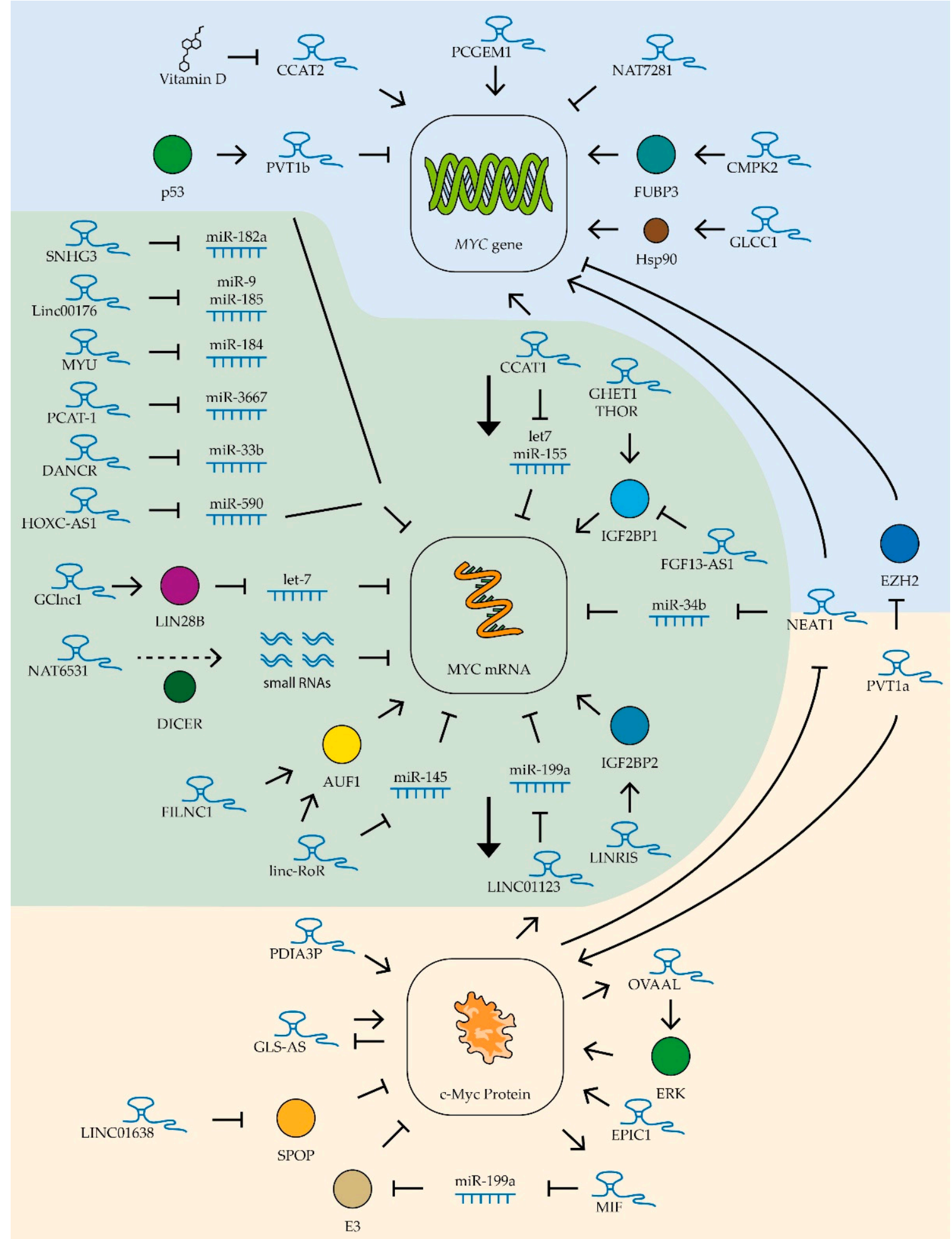

Figure 4. Control of MYC expression by lncRNAs. Schematic representation of lncRNAs' influence on MYC gene transcription (blue zone), MYC mRNA (green zone), and c-Myc protein stability (yellow zone). The colored circles indicate the proteins included in the pathway, the dotted line is product processing. See text for description and references.

\subsection{IncRNAs Controlling MYC Gene Expression in Different Tumor Types}

Several lncRNAs are currently known to regulate MYC gene expression in various tumor types (Table 2). Of these, the most studied is the ceRNA colon cancer-associated 
transcript-1 (CCAT1) whose increased expression was first detected in colon cancer cells in 2011 [208]. This lncRNA has been shown to stimulate tumor growth, vascularization, and metastatic activity [209]. Increased expression of CCAT1 was also found in leukemia, lung, gastric, liver, gallbladder, kidney, prostate, and ovarian cancer cells. CCAT1 lncRNA stimulated cell survival, proliferation, and migration in these tumors [149,208,210-215]. Thus far, two main mechanisms of action of this RNA on MYC gene expression are known. Firstly, CCAT1 is involved in the spatial proximity of its locus (MYC-515), located $515 \mathrm{~kb}$ before the MYC promoter, and the enhancer (MYC-335), located $335 \mathrm{~kb}$ before the aforementioned promoter. This interaction enhances the transcription of this proto-oncogene in tumor cells [216]. Secondly, as mentioned in the previous section, CCAT1 protects the MYC gene mRNA by binding miRNAs let-7 and miR-155 [140,149] (Figure 4).

Table 2. IncRNAs that control the expression of the MYC gene in tumors of various human organs.

\begin{tabular}{|c|c|c|c|c|}
\hline Cancer & $\operatorname{lncRNA}$ & Alteration in Cancer & $\begin{array}{c}\text { Mechanistically } \\
\text { \{Association with the Altered } \\
\text { Level of this RNA in Tumor Cells\} }\end{array}$ & References \\
\hline $\begin{array}{l}\text { Acute myeloid } \\
\text { leukemia }\end{array}$ & CCAT1 & Up-regulated & $\begin{array}{c}\text { Promotes cancer cell proliferation } \\
\text { and survival }\end{array}$ & [149] \\
\hline \multirow{4}{*}{ Bladder cancer } & GClnc1 & Up-regulated & $\begin{array}{l}\text { Promotes cancer cell proliferation, } \\
\text { metastasis, and invasiveness }\end{array}$ & [217] \\
\hline & GHET1 & Up-regulated & $\{$ Predicts an unfavorable survival $\}$ & [218] \\
\hline & NEAT1 & Up-regulated & $\begin{array}{l}\text { Promotes cancer cell proliferation, } \\
\text { invasion, and survival }\end{array}$ & [219] \\
\hline & PVT1a & Up-regulated & $\begin{array}{l}\text { Promotes cancer cell proliferation } \\
\text { and invasion }\end{array}$ & [220] \\
\hline \multirow{5}{*}{ Breast cancer } & EPIC1 & Up-regulated & $\begin{array}{l}\text { Promotes cancer cell proliferation } \\
\text { and survival }\end{array}$ & [221] \\
\hline & GHET1 & Up-regulated & $\{$ Predicts an unfavorable survival $\}$ & [218] \\
\hline & FGF13-AS1 & Down-regulated & $\begin{array}{l}\text { Suppresses cancer cell proliferation, } \\
\text { migration, and invasion }\end{array}$ & [222] \\
\hline & LINC01638 & Up-regulated & $\{$ Predicts a poor outcome $\}$ & [97] \\
\hline & Linc-RoR & Up-regulated & Suppresses cancer cell proliferation & [223] \\
\hline Cervical cancer & MIF & Down-regulated & Suppresses cancer cell proliferation & [59] \\
\hline Cholangiocarcinoma & EPIC1 & Up-regulated & Promotes cancer cell proliferation & [224] \\
\hline $\begin{array}{l}\text { Chronic myeloid } \\
\text { leukemia }\end{array}$ & NEAT1 & Up-regulated & $\begin{array}{l}\text { Promotes cancer cell proliferation } \\
\text { and survival }\end{array}$ & [225] \\
\hline \multirow{7}{*}{ Colon cancer } & CCAT1 & Up-regulated & $\begin{array}{l}\text { Promotes cancer cell proliferation, } \\
\text { migration, and invasion }\end{array}$ & [213] \\
\hline & CCAT2 & Up-regulated & $\begin{array}{l}\text { Promotes metastatic progression } \\
\text { and chromosomal instability in } \\
\text { colon cancer }\end{array}$ & [226] \\
\hline & Linc-RoR & Up-regulated & Promotes cancer cell proliferation & [223] \\
\hline & PVT1a & Up-regulated & $\begin{array}{c}\text { Promotes cancer cell proliferation } \\
\text { and invasion }\end{array}$ & [227] \\
\hline & THOR & Up-regulated & $\begin{array}{l}\text { Promotes cancer cell proliferation } \\
\text { and migration }\end{array}$ & [228] \\
\hline & AUF1 & Up-regulated & Promotes cancer cell proliferation & [223] \\
\hline & EPIC1 & Up-regulated & $\begin{array}{c}\text { Promotes cancer cell proliferation } \\
\text { and invasion }\end{array}$ & [229] \\
\hline
\end{tabular}


Table 2. Cont.

\begin{tabular}{|c|c|c|c|c|}
\hline Cancer & $\operatorname{lncRNA}$ & Alteration in Cancer & $\begin{array}{c}\text { Mechanistically } \\
\text { \{Association with the Altered } \\
\text { Level of this RNA in Tumor Cells\} }\end{array}$ & References \\
\hline \multirow{7}{*}{ Colorectal cancer } & GHET1 & Up-regulated & Promotes cancer cell proliferation & [230] \\
\hline & GLCC1 & Up-regulated & $\begin{array}{l}\text { Promotes cancer cell survival and } \\
\text { proliferation }\end{array}$ & [231] \\
\hline & LINRIS & Up-regulated & Promotes cancer cell proliferation & [232] \\
\hline & NEAT1 & Up-regulated & $\begin{array}{l}\text { Promotes cancer cell proliferation } \\
\text { and survival }\end{array}$ & {$[233,234]$} \\
\hline & SNHG3 & Up-regulated & Promotes cancer cell proliferation & [157] \\
\hline & OVAAL & Up-regulated & Promotes cancer cell proliferation & [206] \\
\hline & CMPK2 & Up-regulated & $\begin{array}{l}\text { Promotes colorectal cancer } \\
\text { progression }\end{array}$ & [235] \\
\hline $\begin{array}{c}\text { Diffuse large B-cell } \\
\text { lymphoma }\end{array}$ & NEAT1 & Up-regulated & $\begin{array}{c}\text { Promotes cancer cell proliferation } \\
\text { and survival }\end{array}$ & [159] \\
\hline $\begin{array}{c}\text { Endometrial } \\
\text { adenocarcinoma }\end{array}$ & NEAT1 & Up-regulated & $\begin{array}{c}\text { Promotes cancer cell proliferation, } \\
\text { invasion, and migration }\end{array}$ & [236] \\
\hline Gallbladder cancer & CCAT1 & Up-regulated & $\begin{array}{l}\text { Promotes cancer cell proliferation } \\
\text { and survival }\end{array}$ & [214] \\
\hline \multirow{3}{*}{ Gastric cancer } & CCAT1 & Up-regulated & $\begin{array}{c}\text { Promotes cancer cell proliferation, } \\
\text { migration, and invasion }\end{array}$ & [237] \\
\hline & GHET1 & Up-regulated & Promotes cancer cell proliferation & [238] \\
\hline & HOXC-AS1 & Up-regulated & $\begin{array}{l}\text { Promotes cancer cell proliferation } \\
\text { and metastasis }\end{array}$ & [165] \\
\hline Glioma & DANCR & Up-regulated & Promotes cancer cell proliferation & [171] \\
\hline \multirow{2}{*}{ Head and neck cancer } & GHET1 & Up-regulated & $\{$ Predicts an unfavorable survival $\}$ & [218] \\
\hline & PCAT-1 & Up-regulated & Promotes cancer cell proliferation & [239] \\
\hline $\begin{array}{l}\text { Hepatocellular } \\
\text { carcinoma }\end{array}$ & PVT1a & Up-regulated & $\begin{array}{l}\text { Promotes cancer cell proliferation } \\
\text { and invasion }\end{array}$ & [240] \\
\hline \multirow{3}{*}{ Liver cancer } & CCAT2 & Up-regulated & $\begin{array}{l}\text { Promotes cancer cell proliferation } \\
\text { and invasion }\end{array}$ & [241] \\
\hline & GHET1 & Up-regulated & $\{$ Predicts an unfavorable survival\} & [218] \\
\hline & Linc00176 & Up-regulated & Promotes cancer cell proliferation & [178] \\
\hline \multirow{7}{*}{ Lung cancer } & CCAT1 & Up-regulated & $\begin{array}{l}\text { Promotes cancer cell proliferation } \\
\text { and survival }\end{array}$ & {$[209,242]$} \\
\hline & EPIC1 & Up-regulated & Promotes cancer cell proliferation & [243] \\
\hline & GHET1 & Up-regulated & $\{$ Predicts an unfavorable survival\} & [218] \\
\hline & LINC01123 & Up-regulated & Promotes cancer cell proliferation & [185] \\
\hline & MIF & Down-regulated & Suppresses cancer cell proliferation & [59] \\
\hline & PVT1a & Up-regulated & $\begin{array}{l}\text { Promotes cancer cell proliferation } \\
\text { and invasion }\end{array}$ & [244] \\
\hline & PVT1b & Down-regulated & Suppresses cancer cell proliferation & [245] \\
\hline Medulloblastoma & DANCR & Up-regulated & Promotes cancer cell proliferation & [171] \\
\hline
\end{tabular}


Table 2. Cont.

\begin{tabular}{|c|c|c|c|c|}
\hline Cancer & lncRNA & Alteration in Cancer & $\begin{array}{c}\text { Mechanistically } \\
\text { \{Association with the Altered } \\
\text { Level of this RNA in Tumor Cells\} }\end{array}$ & References \\
\hline \multirow{2}{*}{ Melanoma } & OVAAL & Up-regulated & Promotes cancer cell proliferation & [206] \\
\hline & THOR & Up-regulated & Promotes cancer cell proliferation & [246] \\
\hline Multiple myeloma & PDIA3P & Up-regulated & $\begin{array}{l}\text { Enhances cancer cell proliferation } \\
\text { and drug resistance }\end{array}$ & [56] \\
\hline $\begin{array}{l}\text { Nasopharyngeal } \\
\text { carcinoma }\end{array}$ & THOR & Up-regulated & Promotes cancer cell proliferation & [247] \\
\hline \multirow{3}{*}{ Esophageal cancer } & CCAT2 & Up-regulated & Promotes radiotherapy resistance & [248] \\
\hline & GHET1 & Up-regulated & $\{$ Predicts an unfavorable survival $\}$ & [218] \\
\hline & AUF1 & Up-regulated & Promotes cancer cell proliferation & [249] \\
\hline Oral cancer & Linc-RoR & Up-regulated & $\begin{array}{l}\text { \{Associated with tumor recurrence } \\
\text { and poor therapeutic response\} }\end{array}$ & [190] \\
\hline \multirow{3}{*}{ Osteosarcoma } & CCAT2 & Up-regulated & $\begin{array}{l}\text { Promotes cancer cell proliferation } \\
\text { and invasion }\end{array}$ & [250] \\
\hline & GHET1 & Up-regulated & $\{$ Predicts an unfavorable survival $\}$ & [218] \\
\hline & THOR & Up-regulated & Promotes cancer cell proliferation & [251] \\
\hline \multirow{3}{*}{ Ovarian cancer } & EPIC1 & Up-regulated & $\begin{array}{c}\text { Promotes cancer cell proliferation } \\
\text { and survival }\end{array}$ & [252] \\
\hline & CCAT1 & Up-regulated & $\begin{array}{l}\text { Promotes cancer cell proliferation } \\
\text { and survival }\end{array}$ & [215] \\
\hline & CCAT2 & Up-regulated & $\begin{array}{l}\text { Promotes cancer cell proliferation } \\
\text { and invasion }\end{array}$ & [253] \\
\hline \multirow{2}{*}{ Pancreatic cancer } & GHET1 & Up-regulated & $\{$ Predicts an unfavorable survival $\}$ & [218] \\
\hline & GLS-AS & Down-regulated & Suppresses cancer cell proliferation & [207] \\
\hline \multirow{5}{*}{ Prostate cancer } & CCAT1 & Up-regulated & $\begin{array}{l}\text { Promotes cancer cell proliferation } \\
\text { and survival }\end{array}$ & [211] \\
\hline & $\begin{array}{l}\text { NAT6531 } \\
\text { NAT7281 }\end{array}$ & Down-regulated & & [254] \\
\hline & PCAT-1 & Up-regulated & Promotes cancer cell proliferation & [195] \\
\hline & PCGEM1 & Up-regulated & $\begin{array}{l}\text { Promotes cancer cell proliferation } \\
\text { and survival }\end{array}$ & [255] \\
\hline & MYU & Up-regulated & Promotes cancer cell proliferation & [198] \\
\hline \multirow[t]{2}{*}{ Renal cancer } & CCAT1 & Up-regulated & $\begin{array}{c}\text { Promotes cancer cell proliferation } \\
\text { and survival }\end{array}$ & [212] \\
\hline & FILNC1 & Down-regulated & Inhibits tumor development & [256] \\
\hline Renal cell carcinoma & THOR & Up-regulated & Promotes cancer cell proliferation & [257] \\
\hline Retinoblastoma & THOR & Up-regulated & Promotes cancer cell proliferation & [258] \\
\hline $\begin{array}{l}\text { Squamous cell } \\
\text { carcinoma }\end{array}$ & NEAT1 & Up-regulated & $\{$ Worse overall survival $\}$ & [259] \\
\hline $\begin{array}{l}\text { Uterine cervical } \\
\text { cancer }\end{array}$ & CCAT2 & Up-regulated & $\begin{array}{c}\text { Progression of uterine cervical } \\
\text { cancer }\end{array}$ & [260] \\
\hline
\end{tabular}

Another lncRNA from the same family, CCAT2, also increases c-Myc levels in colon cancer cells, but by recruiting the transcription factor TCF7L2 to the MYC gene promoter [226]. It was shown that the expression level of this lncRNA in ovarian cancer cells 
can be suppressed by vitamin D metabolites, which reduces the ability of tumor cells for invasive growth [253] (Figure 4). Additionally, high levels of CCAT2 lncRNA enhance the ability of osteosarcoma and hepatocellular carcinoma cells to invade and proliferate [241,250] and improve the resistance to radiotherapy of esophageal cancer cells [248]. The more common rs6983267(G) polymorphism variant of the CCAT2 gene has been shown to be associated with increased MYC gene expression levels and accelerated cervical cancer progression [260].

Another lncRNA affecting MYC expression in various tumor types is NEAT1, which forms specific nuclear structures called paraspeckles. These structures are involved in the maturation and retention of different types of RNA in the nucleus [261]. Elevated NEAT1 levels are associated with suppression of miR-34b activity and increased MYC gene expression in B-cell lymphoma cells [159]. In addition, NEAT1 is involved in the activation of histone acetylation in the MYC gene promoter region, activating its function [233]. It is worth noting that NEAT1 expression is in turn repressed by the c-Myc factor, which creates a negative regulatory loop [159] (Figure 4). Constitutive repression of NEAT1 lncRNA expression decreases proliferation capacity, reduces survival, and increases chemotherapeutic drug sensitivity in chronic myeloid leukemia [225], diffuse B-cell lymphoma [159], bladder cancer [219], uterine cancer [236], and rectal cancer [233,234].

Another lncRNA whose expression correlates positively with MYC expression is THOR. This lncRNA interacts with the insulin-like growth factor 2 mRNA-binding protein (IGF2BP1). The THOR-IGF2BP1 complex increases the mRNA stability of several proto-oncogenes, including the MYC gene [246] (Figure 4). Suppression of this lncRNA's expression leads to decreased proliferation and migration ability of colon cancer cells [228]. High THOR expression accelerates tumor transformation of retinoblastoma cells [258] and growth of osteosarcoma, nasopharyngeal, and renal tumors [247,251,257].

GHET1 lncRNA also increases the stability of MYC gene mRNA through interaction with IGF2BP1 protein (Figure 4). Suppression of this lncRNA expression in gastric and colorectal cancer cells leads to reduced c-Myc levels and suppression of tumor cell proliferation [230,262]. High levels of GHET1 lncRNA expression in tumor cells are associated with poor prognosis in patients with lung, breast, head and neck, nasopharyngeal, stomach, liver, pancreatic, bowel, bladder, and osteosarcoma cancers [218]. High levels of expression of LINRIS lncRNA have been detected in colon cancer cells. This lncRNA stabilizes IGF2BP2, another member of this family of proteins, that extend the lifespan of MYC mRNA [232] (Figure 4).

Amplification of the locus containing the MYC gene has been observed in many tumor types. Moreover, the same locus contains several genes encoding lncRNAs. The expression of one such lncRNA, PVT1a, was shown to be up-regulated in $98 \%$ of tumors with amplification of the locus containing the MYC gene. Moreover, suppression of this lncRNA expression in such cells resulted in reduced MYC expression levels and suppressed proliferation [227]. It was found that PVT1a lncRNA can interact with the c-Myc factor, preventing its degradation. Suppression of this lncRNA's expression has been shown to reduce the ability of lung, colon, and bladder cancer cells to proliferate, migrate, and grow invasively [220,227,244,263]. Recently, it was also shown that PVT1a lncRNA stimulates invasive growth of hepatitis B virus-infected liver cancer cells through stimulation of MYC gene transcription; this lncRNA blocks histone methyltransferase EZH2, which inhibits MYC promoter activity through methylation of lysine 27 on histone H3 [240] (Figure 4).

While searching for potentially oncogenic lncRNAs, EPIC1 RNA was found. This lncRNA interacts directly with the c-Myc protein and stimulates binding of this transcription factor to the promoters of genes controlling the cell cycle. It has also been shown that lncRNA EPIC1 can moderately enhance the Myc-Max interaction [221] (Figure 4). In addition to binding to the c-Myc factor, EPIC1 lncRNA is a potential regulator of the AKT-mTORC1 signaling pathway. The mTOR-specific inhibitor rapamycin is used for the therapy of some types of cancer, but cases of resistance to this drug have been described [264]. EPIC1 knockdown makes resistant breast and ovarian cancer cells sensitive 
to rapamycin [252]. High expression of EPIC1 lncRNA accelerates proliferation of lung cancer cells [243] and cholangiocarcinoma cells [224] and enhances invasive growth of colon cancer cells [229].

\subsection{IncRNAs Controlling MYC Gene Expression in Digestive Tumors}

Several other lncRNAs controlling the level and stability of c-Myc factor in tumor cells were found for digestive system cancers (Table 2). For example, Linc-RoR lncRNA stabilizes MYC gene mRNA in colon cancer cells by controlling its interaction with AU-rich element RNA-binding protein 1 (AUF1) and heterogeneous nuclear ribonucleoprotein I (hnRNPI) [223]. The expression of this lncRNA was also elevated in esophageal tumors [249]. In oral squamous cell cancer cells, Linc-RoR lncRNA binds miRNA miR-145-5p, blocking its binding to MYC gene mRNA [190] (Figure 4). A similar mechanism has been described for other lncRNAs whose increased expression is associated with high levels of c-Myc in cancer cells of the digestive system. For example, in gastric cancer cells, the ceRNA HOXC-AS1 binds miR-590-3p [165], in colon cancer cells the ceRNA SNHG3 suppresses miR-182-5p activity [157], and ceRNA Linc00176 blocks the binding of miR-9 and miR-185-5p to MYC mRNA in hepatocellular carcinoma cells [178] (Figure 4). Enhanced expression of CMPK2 lncRNA, which stabilizes far upstream element (FUSE)-binding protein 3 (FUBP3) and promotes its binding to the MYC gene regulatory element, was also found in colon cancer cells, resulting in activation of transcription of the MYC proto-oncogene [235]. Under conditions of glucose deficiency in rectal cancer cells, GLCC1 lncRNA expression is activated, which activates the interaction of the transcription factor c-Myc with the heat shock protein Hsp90, which prevents ubiquitination and degradation of this factor [231] (Figure 4).

\subsection{IncRNAs Controlling MYC Gene Expression in Urinary Tumor Cells}

Increased expression of GClnc1 lncRNA is an indicator of lower survival chances in bladder cancer. High levels of GClnc1 significantly promoted cell proliferation, metastasis, and tumor invasiveness [217]. GClnc1 binds to LIN28B and activates this protein, and LIN28B, as described in the previous section, is involved in degrading the miRNA of the the miR-let-7 family that controls MYC gene expression (Figure 4).

For lncRNA FILNC1, the ability to bind to the previously mentioned AUF1 protein, which controls the stability of many cellular mRNAs, including MYC, was shown (Figure 4). FILNC1 lncRNA expression in renal cancer cells is stimulated under conditions of ATP deficiency and leads to suppression of MYC expression and decreased tumor cell survival. Low levels of FILNC1 lncRNA in renal tumor cells are associated with a negative prognosis [256].

\subsection{IncRNAs Controlling MYC Gene Expression in Prostate Cancer Cells}

An interesting mechanism for regulating MYC oncogene expression was found in prostate cancer cell culture by switching the expression of three overlapping lncRNAs, NAT6531, NAT6558, and NAT7281. The scenario in the cell in this case is determined by the work of histone deacetylases. Their high activity promotes the transcription of only NAT6531 lncRNA. This lncRNA is a substrate for DICER nuclease, which slices it to form small RNAs that bind to MYC gene RNA and act as miRNA (Figure 4). Weak suppression of deacetylase activity increases the acetylation of histone $\mathrm{H} 3$ at the locus described, which blocks the transcription of NAT6531 and activates the transcription of lncRNA NAT6558. NAT6558 lncRNA does not form a loop that interacts with DICER nuclease and is not a source of small RNAs that decrease the half-life of MYC gene mRNA. When histone deacetylases are completely repressed, the longest lncRNA of this group, NAT7281, is synthesized and the transcription of NAT6531 and NAT6558 is blocked. Expression of NAT7281 leads to a strong suppression of MYC gene transcription [254] (Figure 4). Another lncRNA has been shown to be involved in the regulation of MYC gene expression in prostate cancer cells. PCGEM1 is a prostate-specific lncRNA that is up-regulated in various tumors of this organ and stimulated by androgens. This lncRNA interacts directly with 
the promoter region of the MYC gene, stimulating its transcription [255]. MYC expression was also found to be up-regulated in prostate cancer cells by elevated levels of ceRNA MYU which binds miR-184. Suppression of MYU RNA expression resulted in decreased levels of MYC expression and suppression of tumor cell proliferation [198]. Another ceRNA found in prostate tumors, PCAT-1, binds miR-3667-3p (Figure 4). Suppression of expression of this ceRNA results in reduced MYC expression and suppression of cancer cell proliferation [195].

\subsection{IncRNAs That Control MYC Gene Expression in Breast Cancer Cells}

Increased expression of LINC01638 lncRNA has been detected in breast cancer tissues compared to normal tissue. This lncRNA promotes the proliferation of breast cancer cells with a triple-negative phenotype. LINC01638 has been shown to interact with cMyc and protect it from SPOP-mediated ubiquitination and degradation [97] (Figure 4). Reduced lncRNA levels of FGF13-AS1 have been detected in breast cancer cells and highly metastatic breast cancer cell lines. FGF13-AS1 inhibits tumor cell proliferation, migration, and invasion. This lncRNA binds specifically to the IGF2BP family of proteins and disrupts the interaction between IGF2BP and MYC mRNA. It leads to a decrease in the lifetime of MYC mRNA and, consequently, a lower level of the corresponding factor. Importantly, the c-Myc factor itself suppresses the expression of FGF13-AS1 [222] (Figure 4). Thus, any suppression of the expression or activity of this transcription factor can activate the FGF13-AS1 lncRNA-mediated regulatory mechanism, enhancing the suppression of MYC gene expression.

\subsection{IncRNAs That Control MYC Gene Expression in Lung Cancer Cells}

Several new lncRNAs affecting c-Myc factor expression have been found in lung cancer cells (Table 2). LINC01123 lncRNA in lung cancer cells forms a positive LINC01123/miR199a-5p/MYC regulatory loop with c-Myc factor (Figure 4). Such regulatory loops may be a prospective target for therapeutic action, as suppression of the expression of this lncRNA inhibits the ability of cancer cells to proliferate [185]. An alternative isoform of the previously described PVT1 lncRNA, PVT1b, was also found in lung cancer cells. This isoform is synthesized under the influence of tumor suppressor p53 and, unlike the PVT1a isoform described above, suppresses the expression of the MYC gene (Figure 4). Increased expression of the PVT1b isoform in cancer cells slows down tumor growth [245].

\subsection{IncRNAs Controlling MYC Gene Expression in Myeloma Cells}

One important role of c-Myc factor in oncogenesis, as was mentioned earlier, is the formation of drug resistance in tumor cells. The role of PDIA3P lncRNA in this process has been demonstrated in multiple myeloma cells. This lncRNA interacts with the c-Myc factor and enhances its stimulatory effect on the glucose-6-phosphate dehydrogenase gene promoter (Figure 4), high levels of which allow for reducing the toxic effect of bortezomib on myeloma cells [56].

\subsection{IncRNAs Controlling MYC Gene Expression in Medulloblastoma Cells}

In nervous system tumors, gliomas and medulloblastomas, the regulation of MYC gene expression was found to be impaired by the binding of miR-33b-5p ceRNA DANCR (Figure 4). Suppression of this ceRNA's expression leads to decreased levels of c-Myc factor and slows down cancer cell proliferation [171].

\section{Circular RNA}

A new type of RNA, circular RNA (circRNA), has been discovered relatively recently. This RNA type is characterized by a closed-loop structure and is, therefore, more resistant against the action of nucleases than linear RNA molecules. CircRNA is formed by splicing, so the same gene can be transcribed to both linear and circular RNA molecules. Due to the absence of a 5 '-end and hence no cap structure, most circRNAs in eukaryotes are non- 
coding. However, circRNAs can perform a number of functions described for lncRNAs: they bind miRNAs, interact with regulatory sequences of the genome, and bind to proteins, altering their functions $[265,266]$.

The role of circRNA in the development of various types of tumors has not been studied as well as for lncRNA and miRNA (Tables 1-3). In this section, we focus on the variety of mechanisms by which they affect c-Myc factor formation, function, and degradation. Some circRNAs bind miRNAs in different types of tumors. For example, increased expression of the cyclic isoform of the aforementioned PVT1 RNA, circPVT1, has been observed in leukemia, gastric, and colon cancer cells. This circRNA can activate MYC gene expression by binding miR-125 and miR-145 (Figure 5). Increased circPVT1 levels are associated with accelerated proliferation and increased tumor cell viability [267]. Similarly, circRNA_103809 enhances the ability of lung cancer cells to invasively grow by binding miR-4302, which suppresses ZNF121-dependent expression of the MYC gene [88] (Figure 5). For another RNA, circCCDC66, the ability to up-regulate MYC gene expression in colon cancer cells through the binding of miR-33b and miR-93 was shown (Figure 5). High levels of this circCCDC66 promote tumor growth and metastasis [155]. Additionally, high levels of this circRNA promote the development of gastric cancer [268]. Two other circRNAs, circLMTK2 and circ-PRMT5, have been shown to bind miR-150-5p, miR-145, and miR-1304 and increase MYC gene expression in gastric cancer cells (Figure 5). Suppression of the expression of these circRNAs reduces the proliferation and migration of tumor cells [166,167] A circRNA, circ_0068307, was also found to stimulate MYC gene expression and bladder cancer cell proliferation by binding miR-147 [150].

Table 3. CircRNAs that control the expression of the MYC gene in tumors of various human organs.

\begin{tabular}{|c|c|c|c|c|}
\hline Cancer & circRNA & Alteration in Cancer & Mechanistically & References \\
\hline \multirow{3}{*}{ Bladder cancer } & CircCDYL & Down-regulated & $\begin{array}{l}\text { Suppresses cell growth and } \\
\text { migration }\end{array}$ & [269] \\
\hline & circNR3C1 & Down-regulated & Suppresses cancer cell growth & [270] \\
\hline & circ_0068307 & Up-regulated & $\begin{array}{c}\text { Promotes cancer cell migration } \\
\text { and proliferation }\end{array}$ & [150] \\
\hline Breast cancer & circ-Amotl1 & Up-regulated & Stimulates tumor growth & [271] \\
\hline \multirow{3}{*}{ Colon cancer } & circPVT1 & Up-regulated & $\begin{array}{l}\text { Promotes cancer cell } \\
\text { proliferation }\end{array}$ & [267] \\
\hline & circCTIC1 & Up-regulated & $\begin{array}{l}\text { Promotes cancer cell } \\
\text { proliferation }\end{array}$ & [272] \\
\hline & circCCDC66 & Up-regulated & $\begin{array}{l}\text { Promotes cancer cell } \\
\text { proliferation and migration }\end{array}$ & [155] \\
\hline \multirow{6}{*}{ Gastric cancer } & circLMTK2 & Up-regulated & $\begin{array}{l}\text { Promotes cancer cell } \\
\text { proliferation }\end{array}$ & [166] \\
\hline & Circ-PRMT5 & Up-regulated & $\begin{array}{l}\text { Promotes cancer cell } \\
\text { proliferation }\end{array}$ & [167] \\
\hline & circ-NOTCH1 & Up-regulated & $\begin{array}{c}\text { Promotes cancer cell migration } \\
\text { and proliferation }\end{array}$ & [168] \\
\hline & circPVT1 & Up-regulated & $\begin{array}{l}\text { Promotes cancer cell } \\
\text { proliferation }\end{array}$ & [267] \\
\hline & circHECTD1 & Up-regulated & $\begin{array}{l}\text { Promotes cancer cell } \\
\text { proliferation }\end{array}$ & [273] \\
\hline & circCCDC66 & Up-regulated & $\begin{array}{l}\text { Promotes cancer cell } \\
\text { proliferation }\end{array}$ & [268] \\
\hline
\end{tabular}


Table 3. Cont.

\begin{tabular}{ccccc}
\hline Cancer & circRNA & Alteration in Cancer & Mechanistically & References \\
\hline Glioblastoma & circ-FBXW7 & Down-regulated & Suppresses cancer cell growth & $\begin{array}{c}\text { Promotes cancer cell } \\
\text { proliferation }\end{array}$ \\
\hline Leukemia & circPVT1 & Up-regulated & Up-regulated & Stimulates tumor growth \\
\hline Liver cancer & circ_0091581 & Up-regulated & $\begin{array}{c}\text { Stimulates cancer cell } \\
\text { proliferation and invasion }\end{array}$ \\
\hline Lung cancer & circRNA_103809 & Up-regulated & $\begin{array}{c}\text { Promotes cancer cell migration } \\
\text { and proliferation }\end{array}$ \\
\hline $\begin{array}{c}\text { Osteosarcoma } \\
\text { carcinoma }\end{array}$ & CircECE1 & Up-regulated & $\begin{array}{c}\text { Promotes cancer cell } \\
\text { proliferation }\end{array}$ \\
\hline circUHRF1 & circ-ITCH & Down-regulated & $\begin{array}{c}\text { Suppresses cancer cell } \\
\text { migration and proliferation }\end{array}$ \\
\hline \begin{tabular}{c} 
Thyroid cancer \\
\cline { 2 - 4 }
\end{tabular} & circRNA_102171 & Up-regulated & $\begin{array}{c}\text { Promotes cancer cell migration } \\
\text { and proliferation }\end{array}$ \\
\hline
\end{tabular}

In some cases, circRNAs form regulatory loops with the MYC gene. For example, in gastric cancer cells, circ-NOTCH1 RNA is involved in the regulation of MYC gene expression. The expression of this circRNA is stimulated by c-Myc factor, while the RNA itself stabilizes MYC gene mRNA by binding miRNA miR-449c-5p [168] (Figure 5). Similarly, in oral squamous cell carcinoma cells, c-Myc factor activates the expression of circUHRF1 RNA, which in turn binds miR-526b, increasing the stability of this factor's mRNA [191].

Some studies are able to trace longer chains of interactions linking circRNA and c-Myc factor activity. Thus, in gastric cancer cells, it was shown that the RNA circHECTD1 binds miR-1256, thus activating expression of the USP5 gene which in turn leads to stabilization of $\beta$-catenin which activates expression of the MYC gene. Another RNA affecting $\beta$ catenin activity is circRNA_102171. This RNA binds to the $\beta$-catenin-interacting protein CTNNBIP1, resulting in increased $\beta$-catenin activity and MYC gene expression in thyroid cancer cells (Figure 5). High levels of this circRNA stimulate tumor growth and the process of metastasis formation [277]. One more RNA which suppresses $\beta$-catenin activity in thyroid tumor cells is circ-ITCH. This circRNA binds miR-22-3p and increases the expression of CBL ubiquitin ligase, which suppresses $\beta$-catenin activity. Increased levels of circ-ITCH also suppress tumor growth and metastasis [276].

In addition to miRNA binding, circ-ITCH RNAs can influence MYC expression through direct interaction with the gene promoter. In colon cancer cells, circCTIC1 RNA binds BPTF and attracts it to the MYC gene promoter (Figure 5). High levels of this circRNA enhance MYC gene transcription and cancer cell proliferation [272]. In contrast, another circRNA, circNR3C1, inhibits the interaction of the BRD4 protein with the MYC gene promoter and suppresses the expression of this gene and bladder tumor cell proliferation [270].

CircRNA is also able to influence the stability and activity of the c-Myc factor itself. For example, the circRNA angiomotin-like1 (circ-Amotl1) binds to c-Myc factor and promotes its stabilization and transport to the nucleus. Increased expression of this RNA in breast cancer cells enhances tumor growth [271]. Another RNA, circECE1, also interacts with c-Myc protein and inhibits its ubiquitination and degradation (Figure 5). Its increased level is associated with activation of osteosarcoma cell proliferation and migration processes, as well as increased oxygen-free metabolism [275]. CircRNAs have also been found to decrease the stability of the c-Myc factor. CircCDYL RNA does not affect the mRNA level of the MYC gene, but it decreases the level of the corresponding protein, apparently decreasing its stability. High levels of this circRNA suppress bladder cancer cell proliferation and migration [269]. 


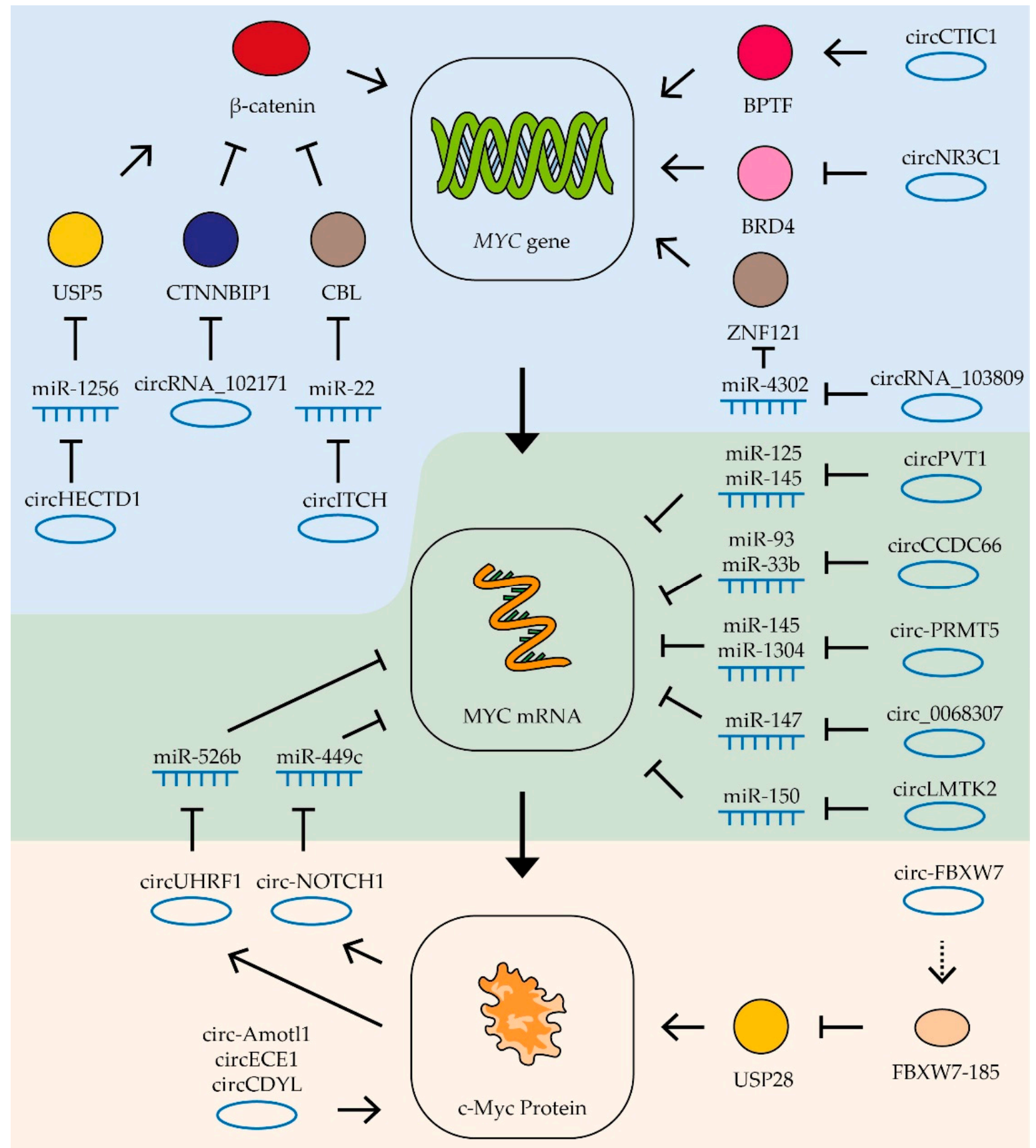

Figure 5. Control of MYC mRNA by circRNAs. Schematic representation of lncRNAs' influence on MYC gene transcription (blue zone), MYC mRNA (green zone), and c-Myc protein stability (yellow zone). Colored circles indicate the proteins included in the pathway, the dotted line is a translation product. See text for description and references.

In rare cases, circRNA can work by means of encoded polypeptides. For example, circ-FBXW7 encodes the FBXW7-185 protein that binds to ubiquitin-specific peptidase 28 (USP28 protein). This protein interaction causes accelerated degradation of the peptidase and disrupts the stabilization of the c-Myc factor by this enzyme (Figure 5). Increased expression of circ-FBXW7 in glioblastoma cells suppresses their proliferation [274]. 


\section{Conclusions}

Numerous data in this review demonstrate that c-Myc plays an important role in the development of a wide variety of cancers. According to current reports, MYC expression levels are elevated in approximately $70 \%$ of human tumors $[278,279]$. However, there are still no drugs widely available in clinical practice which aim at suppressing the expression or activity of this oncogene [280]. Typically, low-molecular-weight compounds that specifically block the activity of the target protein are developed to block oncogene activity. However, the c-Myc molecule is not an enzyme and lacks the "pockets" to which low-molecular-weight inhibitors are usually matched [280,281]. To date, several molecules have been found that disrupt the binding of c-Myc and its partner Max, and stimulate c-Myc degradation by facilitating its phosphorylation by threonine 58 and subsequent ubiquitination [282]. A study of these molecules in animal models showed that the use of these inhibitors resulted in the enrichment of the tumor with cells with high PD-L1 expression, indicating the need for simultaneous use of c-Myc and PD-1 inhibitors [282]. Due to the high rate of change in c-Myc levels, prolonged and continuous exposure to these transcriptional factor inhibitors is required to effectively suppress its expression. The narrow therapeutic window of currently developed drugs makes it difficult to use them for tumor therapy [280].

An alternative approach to suppress c-Myc levels is the use of siRNA analogs. Two studies of such molecules currently exist, but both have been halted due to sponsor rejection (NCT02110563; NCT0231405). The use of RNA- and DNA-based drugs has been underdeveloped until recently due to low stability, difficulties in targeted delivery, and possible side effects [283]. However, the widespread use of RNA- and DNA-based vaccines against SARS-CoV2 could significantly advance the use of RNA- and DNA-containing drugs. The use of nuclease-protected siRNA analogs and single-stranded DNA complementary to target RNA may be an effective way to reduce the expression of certain genes in the long term [284]. However, in the case of the MYC gene, the question of the optimal sequence selection for the annealing therapeutic molecule arises. Known natural miRNAs that inhibit c-Myc synthesis may have additional targets, which may vary for different cell types. In addition, the set of lncRNAs and circRNAs capable of blocking certain miRNAs may differ in different cell types. When selecting a target, it is also important to consider positive and negative regulatory loops. As one of the solutions, a more long-lasting effect can be achieved by simultaneously blocking several RNAs involved in different regulatory loops.

This review describes different types of RNA that control MYC gene expression in different tissues and tumor types (Tables 1-3; Figure 6). Especially noteworthy is the diversity of different types of RNAs controlling the expression of this proto-oncogene in cells of digestive system cancers (Tables 1-3; Figure 7). Using tissue-specific regulatory RNAs rather than MYC gene mRNA as targets provides a potential opportunity to selectively influence c-Myc expression in cells of a particular tumor type. This may allow for creating a drug with a more selective effect and, consequently, a wider therapeutic window. It is worth noting that the studies on the role of different RNAs in the regulation of MYC expression in different cell types are not exhaustive, and some of the mentioned RNAs may function in a wider range of tissues and tumors than is currently known.

Thus, the information provided in this review indicates the possibility of developing a specific diagnosis and treatment for different tumor types. Since suppression of MYC expression can reduce cell resistance to chemotherapy and radiotherapy, the use of tumorspecific MYC inhibitors can be applied to create effective anti-tumor therapy options. 


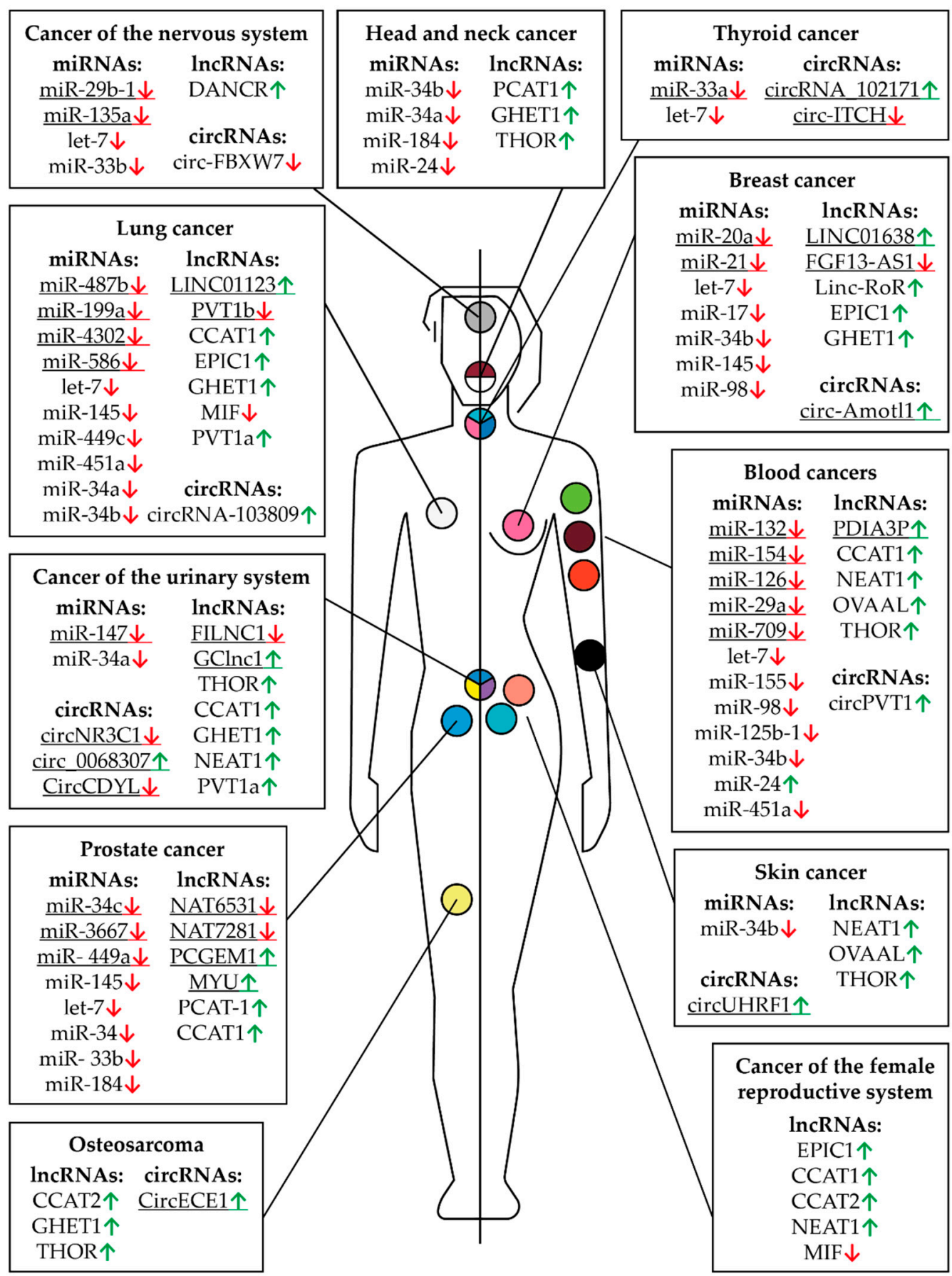

Figure 6. Controlling MYC RNAs in different types of cancer except those of the digestive system. The fields indicate miRNAs, lncRNAs, and circRNAs that have altered expression compared to healthy tissues in a particular cancer. Arrows indicate an increased (green) or decreased (red) level of RNA in a particular type of cancer. The human body (the left part is a male, the right part is female) and the location of cancer tumors are presented schematically. The colored circles indicate a particular type of cancer: burgundy—multiple myeloma, orange-leukemia, pink—breast cancer, peach-uterine or endometrial cancer, yellow—sarcoma or bone cancer, lime green—non-Hodgkin lymphoma, teal—ovarian cancer, light blue-prostate cancer, black—skin cancer, gray—brain cancer, white-lung cancer, blue, yellow, and purple-bladder cancer, blue, pink, and teal—thyroid cancer, white and burgundy-head and neck cancer. The underlined RNAs are currently believed to be tissue specific but new roles can potentially be discovered. 


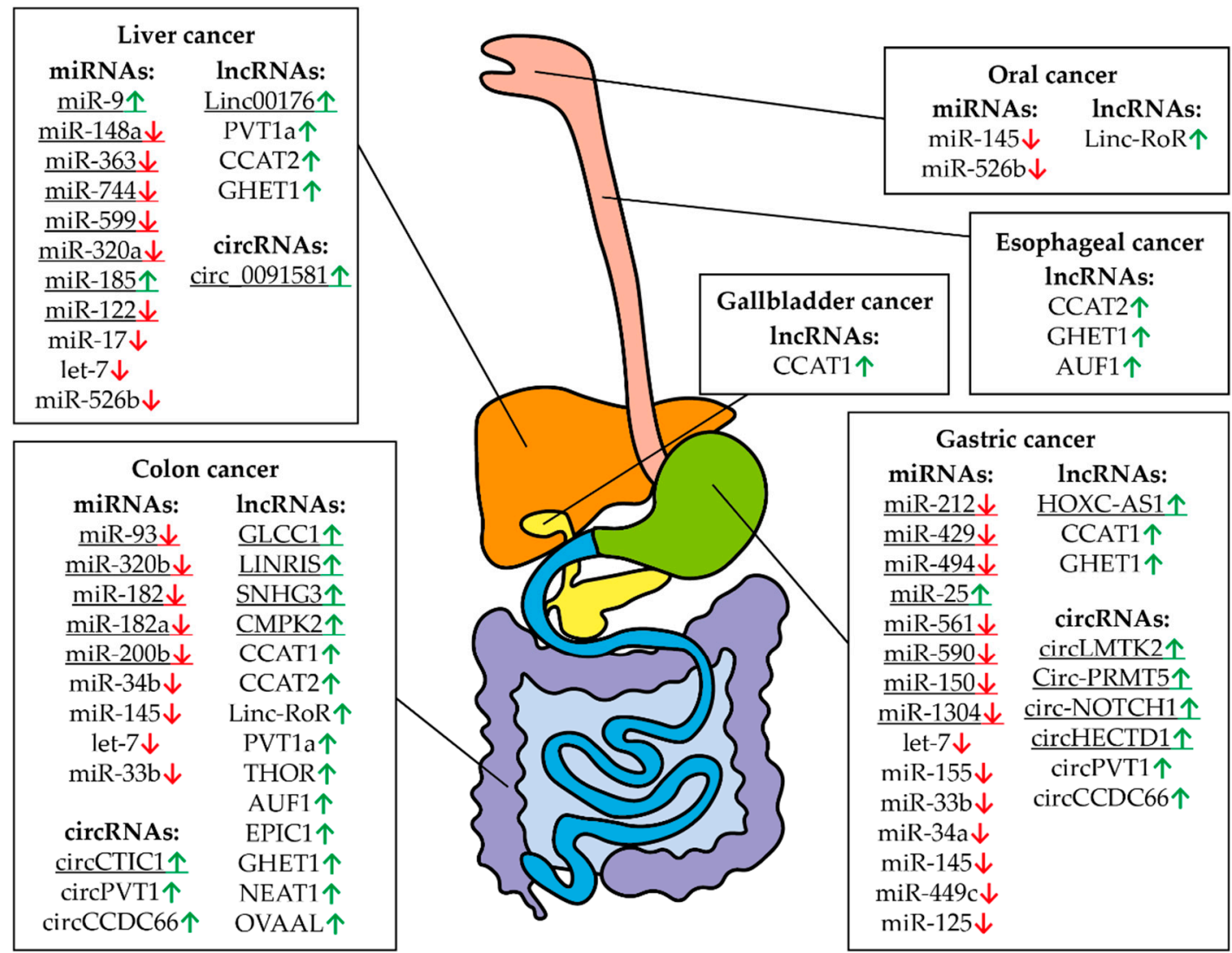

Figure 7. Controlling MYC RNAs in different types of digestive system cancers. The fields indicate miRNAs, lncRNAs, and circRNAs that have altered expression compared to healthy tissues in a particular cancer. Arrows indicate an increased (green) or decreased (red) level of RNA in a particular type of cancer. The digestive system is represented schematically. The underlined RNAs are currently believed to be tissue specific but new roles can potentially be discovered.

Author Contributions: Conceptualization, A.M.S.; writing-original draft preparation, E.M.S., M.M.M., D.E.D. and A.M.S.; writing-review and editing, L.S.Z.; visualization, E.M.S.; supervision, A.M.S.; funding acquisition, A.M.S. All authors have read and agreed to the published version of the manuscript.

Funding: Work on most sections of this article was supported by the Russian Science Foundation (project no. 19-74-10083). Data analysis for Section 2 "miRNAs" was supported by grant 075-15-20191660 from the Ministry of Science and Higher Education of the Russian Federation.

Institutional Review Board Statement: Not applicable.

Informed Consent Statement: Not applicable.

Acknowledgments: We thank D.V. Kuprash from the Center for Precision Genome Editing and Genetic Technologies for Biomedicine, Engelhardt Institute of Molecular Biology for helpful discussions.

Conflicts of Interest: The authors declare no conflict of interest.

\section{References}

1. DePinho, R.; Mitsock, L.; Hatton, K.; Ferrier, P.; Zimmerman, K.; LeGouy, E.; Tesfaye, A.; Collum, R.; Yancopoulos, G.; Nisen, P.; et al. Myc family of cellular oncogenes. J. Cell. Biochem. 1987, 33, 257-266. [CrossRef] [PubMed]

2. Colby, W.W.; Chen, E.Y.; Smith, D.H.; Levinson, A.D. Identification and nucleotide sequence of a human locus homologous to the v-myc oncogene of avian myelocytomatosis virus MC29. Nat. Cell Biol. 1983, 301, 722-725. [CrossRef] [PubMed]

3. Kohl, N.; Gee, C.; Alt, F. Activated expression of the N-myc gene in human neuroblastomas and related tumors. Science 1984, 226, 1335-1337. [CrossRef] 
4. Nau, M.M.; Brooks, B.J.; Battey, J.F.; Sausville, E.; Gazdar, A.F.; Kirsch, I.R.; McBride, O.W.; Bertness, V.L.; Hollis, G.F.; Minna, J.D. L-myc, a new myc-related gene amplified and expressed in human small cell lung cancer. Nat. Cell Biol. 1985, $318,69-73$. [CrossRef] [PubMed]

5. Dang, C.V.; O’Donnell, K.A.; Zeller, K.I.; Nguyen, T.; Osthus, R.C.; Li, F. The c-Myc target gene network. Semin. Cancer Biol. 2006, 16, 253-264. [CrossRef]

6. Karn, J.; Watson, J.V.; Lowe, A.D.; Green, S.M.; Vedeckis, W. Regulation of cell cycle duration by c-myc levels. Oncogene 1989, 4 , 773-787.

7. Hanson, K.D.; Shichiri, M.; Follansbee, M.R.; Sedivy, J.M. Effects of c-myc expression on cell cycle progression. Mol. Cell. Biol. 1994, 14, 5748-5755. [CrossRef]

8. Benaud, C.M.; Dickson, R.B. Adhesion-regulated G1 cell cycle arrest in epithelial cells requires the downregulation of c-Myc. Oncogene 2001, 20, 4554-4567. [CrossRef]

9. Hirning, U.; Schmid, P.; Schulz, W.; Rettenberger, G.; Hameister, H. A comparative analysis of N-myc and c-myc expression and cellular proliferation in mouse organogenesis. Mech. Dev. 1991, 33, 119-125. [CrossRef]

10. Hirning, U.; Schmid, P.; Schulz, W.; Kozak, L.; Hameister, H. In developing brown adipose tissue c-myc protooncogene expression is restricted to early differentiation stages. Cell Differ. Dev. 1989, 27, 243-248. [CrossRef]

11. Schmid, P.; Schulz, W.; Hameister, H. Dynamic expression pattern of the myc protooncogene in midgestation mouse embryos. Science 1989, 243, 226-229. [CrossRef]

12. Douglas, N.; Jacobs, H.; Bothwell, A.L.M.; Hayday, A.C. Defining the specific physiological requirements for c-Myc in T cell development. Nat. Immunol. 2001, 2, 307-315. [CrossRef] [PubMed]

13. Iritani, B.M.; Eisenman, R.N. c-Myc enhances protein synthesis and cell size during B lymphocyte development. Proc. Natl. Acad. Sci. USA 1999, 96, 13180-13185. [CrossRef] [PubMed]

14. Loftus, R.; Assmann, N.; Kedia-Mehta, N.; O’Brien, K.L.; Garcia, A.; Gillespie, C.; Hukelmann, J.; Oefner, P.J.; Lamond, A.; Gardiner, C.; et al. Amino acid-dependent cMyc expression is essential for NK cell metabolic and functional responses in mice. Nat. Commun. 2018, 9, 1-15. [CrossRef]

15. Wei, Y.; Resetca, D.; Li, Z.; Johansson-Åkhe, I.; Ahlner, A.; Helander, S.; Wallenhammar, A.; Morad, V.; Raught, B.; Wallner, B.; et al. Multiple direct interactions of TBP with the MYC oncoprotein. Nat. Struct. Mol. Biol. 2019, 26, 1035-1043. [CrossRef]

16. Xu, D.; Dwyer, J.; Li, H.; Duan, W.; Liu, J.-P. Ets2 Maintains hTERT Gene Expression and Breast Cancer Cell Proliferation by Interacting with c-Myc. J. Biol. Chem. 2008, 283, 23567-23580. [CrossRef]

17. Brenner, C.; Deplus, R.; Loriot, A.; De Smet, C.; Gutierrez, A.; Danovi, D.; Bernard, D.; Boon, T.; Pelicci, P.G.; Amati, B.; et al. Myc represses transcription through recruitment of DNA methyltransferase corepressor. EMBO J. 2004, 24, 336-346. [CrossRef] [PubMed]

18. Ullius, A.; Lüscher-Firzlaff, J.; Costa, I.G.; Walsemann, G.; Forst, A.H.; Gusmao, E.G.; Kapelle, K.; Kleine, H.; Kremmer, E.; Vervoorts, J.; et al. The interaction of MYC with the trithorax protein ASH2L promotes gene transcription by regulating H3K27 modification. Nucleic Acids Res. 2014, 42, 6901-6920. [CrossRef] [PubMed]

19. Nguyen, L.; Papenhausen, P.; Shao, H. The Role of c-MYC in B-Cell Lymphomas: Diagnostic and Molecular Aspects. Genes 2017, 8, 116. [CrossRef] [PubMed]

20. Casulo, C.; Friedberg, J.W. Burkitt lymphoma- a rare but challenging lymphoma. Best Pr. Res. Clin. Haematol. 2018, 31, 279-284. [CrossRef]

21. Alves, R.D.C.S.; Meurer, R.T.; Roehe, A.V. MYC amplification is associated with poor survival in small cell lung cancer: A chromogenic in situ hybridization study. J. Cancer Res. Clin. Oncol. 2014, 140, 2021-2025. [CrossRef] [PubMed]

22. Wolfer, A.; Wittner, B.S.; Irimia, D.; Flavin, R.; Lupien, M.; Gunawardane, R.N.; Meyer, C.A.; Lightcap, E.S.; Tamayo, P.; Mesirov, J.P.; et al. MYC regulation of a "poor-prognosis" metastatic cancer cell state. Proc. Natl. Acad. Sci. USA 2010, 107, 3698-3703. [CrossRef]

23. Pan, W.; Wang, W.; Huang, J.; Lu, K.; Huang, S.; Jiang, D.; Bu, D.; Liu, J.; Jing, H.; Yao, J.; et al. The prognostic role of c-MYC amplification in schistosomiasis-associated colorectal cancer. Jpn. J. Clin. Oncol. 2020, 50, 446-455. [CrossRef] [PubMed]

24. Hanahan, D.; Weinberg, R.A. Hallmarks of Cancer: The Next Generation. Cell 2011, 144, 646-674. [CrossRef] [PubMed]

25. Chanvorachote, P.; Sriratanasak, N.; Nonpanya, N. C-myc Contributes to Malignancy of Lung Cancer: A Potential Anticancer Drug Target. Anticancer. Res. 2020, 40, 609-618. [CrossRef]

26. Cappellen, D.; Schlange, T.; Bauer, M.; Maurer, F.; Hynes, N. Novel c-MYC target genes mediate differential effects on cell proliferation and migration. EMBO Rep. 2006, 8, 70-76. [CrossRef] [PubMed]

27. Wang, J.; Wang, H.; Li, Z.; Wu, Q.; Lathia, J.D.; McLendon, R.E.; Hjelmeland, A.B.; Rich, J.N. c-Myc Is Required for Maintenance of Glioma Cancer Stem Cells. PLoS ONE 2008, 3, e3769. [CrossRef]

28. Eilers, M. Control of cell proliferation by Myc family genes. Mol. Cells 1999, 9, 1-6.

29. Pelengaris, S.; Rudolph, B.; Littlewood, T. Action of Myc in vivo - proliferation and apoptosis. Curr. Opin. Genet. Dev. 2000, 10, 100-105. [CrossRef]

30. Swier, L.J.Y.M.; Dzikiewicz-Krawczyk, A.; Winkle, M.; Berg, A.V.D.; Kluiver, J. Intricate crosstalk between MYC and non-coding RNA s regulates hallmarks of cancer. Mol. Oncol. 2019, 13, 26-45. [CrossRef]

31. Aziz, N.; Hong, Y.H.; Jo, M.K.; Kim, J.K.; Kim, K.-H.; Ashktorab, H.; Smoot, D.T.; Hur, H.; Yoo, B.C.; Cho, A.J.Y. Molecular Signatures of JMJD10/MINA53 in Gastric Cancer. Cancers 2020, 12, 1141. [CrossRef] 
32. Tsuneoka, M.; Koda, Y.; Soejima, M.; Teye, K.; Kimura, H. A Novel Myc Target Gene, mina53, That Is Involved in Cell Proliferation. J. Biol. Chem. 2002, 277, 35450-35459. [CrossRef]

33. Zhou, L.; Zhang, T.; Zhu, Q.; Zhang, P.; Yu, L.; Shen, B.; Yi, W.; Qiu, M.; Zhu, C. Mina53 regulates the differentiation and proliferation of leukemia cells. Hematol. Oncol. 2019, 37, 513-515. [CrossRef] [PubMed]

34. Swarbrick, A.; Åkerfeldt, M.C.; Lee, C.S.L.; Sergio, C.M.; Caldon, C.E.; Hunter, L.-J.K.; Sutherland, R.L.; Musgrove, E. Regulation of cyclin expression and cell cycle progression in breast epithelial cells by the helix-loop-helix protein Id1. Oncogene 2004, 24, 381-389. [CrossRef] [PubMed]

35. Cheng, Y.-J.; Tsai, J.-W.; Hsieh, K.-C.; Yang, Y.-C.; Chen, Y.-J.; Huang, M.-S.; Yuan, S.-S. Id1 promotes lung cancer cell proliferation and tumor growth through Akt-related pathway. Cancer Lett. 2011, 307, 191-199. [CrossRef] [PubMed]

36. Mannava, S.; Grachtchouk, V.; Wheeler, L.J.; Im, M.; Zhuang, D.; Slavina, E.G.; Mathews, C.K.; Shewach, D.S.; Nikiforov, M.A. Direct role of nucleotide metabolism in C-MYC-dependent proliferation of melanoma cells. Cell Cycle 2008, 7, 2392-2400. [CrossRef] [PubMed]

37. Cerni, C. Telomeres, telomerase, and myc. An update. Mutat. Res. Mutat. Res. 2000, 462, 31-47. [CrossRef]

38. Louis, S.F.; Vermolen, B.J.; Garini, Y.; Young, I.T.; Guffei, A.; Lichtensztejn, Z.; Kuttler, F.; Chuang, T.C.Y.; Moshir, S.; Mougey, V.; et al. c-Myc induces chromosomal rearrangements through telomere and chromosome remodeling in the interphase nucleus. Proc. Natl. Acad. Sci. USA 2005, 102, 9613-9618. [CrossRef] [PubMed]

39. Ermler, S.; Krunic, D.; Knoch, T.A.; Moshir, S.; Mai, S.; Greulich-Bode, K.M.; Boukamp, P. Cell cycle-dependent 3D distribution of telomeres and telomere repeat-binding factor 2 (TRF2) in HaCaT and HaCaT-myc cells. Eur. J. Cell Biol. 2004, 83, 681-690. [CrossRef]

40. Okamoto, K.; Bartocci, C.; Ouzounov, I.; Diedrich, J.K.; Iii, J.R.Y.; Denchi, E.L. A two-step mechanism for TRF2-mediated chromosome-end protection. Nat. Cell Biol. 2013, 494, 502-505. [CrossRef]

41. Vafa, O.; Wade, M.; Kern, S.; Beeche, M.; Pandita, T.K.; Hampton, G.M.; Wahl, G.M. c-Myc Can Induce DNA Damage, Increase Reactive Oxygen Species, and Mitigate p53 Function: A Mechanism for Oncogene-Induced Genetic Instability. Mol. Cell 2002, 9, 1031-1044. [CrossRef]

42. Tanaka, H.; Matsumura, I.; Ezoe, S.; Satoh, Y.; Sakamaki, T.; Albanese, C.; Machii, T.; Pestell, R.G.; Kanakura, Y. E2F1 and c-Myc Potentiate Apoptosis through Inhibition of NF-kB Activity that Facilitates MnSOD-Mediated ROS Elimination. Mol. Cell 2002, 9 , 1017-1029. [CrossRef]

43. Dang, C.V.; Li, F.; Lee, L.A. Could MYC Induction of Mitochondrial Biogenesis be linked to ROS Production and Genomic Instability? Cell Cycle 2005, 4, 1465-1466. [CrossRef]

44. Kumari, A.; Folk, W.P.; Sakamuro, D. The Dual Roles of MYC in Genomic Instability and Cancer Chemoresistance. Genes 2017, 8, 158. [CrossRef] [PubMed]

45. Walker, T.; White, J.; Esdale, W.; Burton, M.; DeCruz, E. Tumour cells surviving in vivo cisplatin chemotherapy display elevated c-myc expression. Br. J. Cancer 1996, 73, 610-614. [CrossRef]

46. Elbadawy, M.; Usui, T.; Yamawaki, H.; Sasaki, K. Emerging Roles of C-Myc in Cancer Stem Cell-Related Signaling and Resistance to Cancer Chemotherapy: A Potential Therapeutic Target Against Colorectal Cancer. Int. J. Mol. Sci. 2019, 20, 2340. [CrossRef]

47. Zuo, Y.; Yang, D.; Yu, Y.; Xiang, M.; Li, H.; Yang, J.; Li, J.; Jiang, D.; Zhou, H.; Xu, Z.; et al. Niclosamide enhances the cytotoxic effect of cisplatin in cisplatin-resistant human lung cancer cells via suppression of lung resistance-related protein and c-myc. Mol. Med. Rep. 2017, 17, 3497-3502. [CrossRef] [PubMed]

48. Leonetti, C.; Biroccio, A.; Candiloro, A.; Citro, G.; Fornari, C.; Mottolese, M.; Del Bufalo, D.; Zupi, G. Increase of cisplatin sensitivity by c-myc antisense oligodeoxynucleotides in a human metastatic melanoma inherently resistant to cisplatin. Clin. Cancer Res. 1999, 5, 2588-2595. [PubMed]

49. Reyes-González, J.M.; Armaiz-Pena, G.N.; Mangala, L.S.; Valiyeva, F.; Ivan, C.; Pradeep, S.; Echevarría-Vargas, I.M.; Rivera-Reyes, A.; Sood, A.K.; Vivas-Mejía, P.E. Targeting c-MYC in Platinum-Resistant Ovarian Cancer. Mol. Cancer Ther. 2015, 14, $2260-2269$. [CrossRef]

50. Daga, M.; Pizzimenti, S.; Dianzani, C.; Cucci, M.A.; Cavalli, R.; Grattarola, M.; Ferrara, B.; Scariot, V.; Trotta, F.; Barrera, G. Ailanthone inhibits cell growth and migration of cisplatin resistant bladder cancer cells through down-regulation of Nrf2, YAP, and c-Myc expression. Phytomedicine 2019, 56, 156-164. [CrossRef]

51. Chen, R.; Guo, S.; Yang, C.; Sun, L.; Zong, B.; Li, K.; Liu, L.; Tu, G.; Liu, M.; Liu, S. Although c-MYC contributes to tamoxifen resistance, it improves cisplatin sensitivity in ER-positive breast cancer. Int. J. Oncol. 2020, 56, 932-944. [CrossRef] [PubMed]

52. Lin, Y.-T.; Lu, H.-P.; Chao, C.C.-K. Oncogenic c-Myc and prothymosin-alpha protect hepatocellular carcinoma cells against sorafenib-induced apoptosis. Biochem. Pharmacol. 2015, 93, 110-124. [CrossRef] [PubMed]

53. Campaner, S.; Amati, B. Two sides of the Myc-induced DNA damage response: From tumor suppression to tumor maintenance. Cell Div. 2012, 7, 6. [CrossRef]

54. Murphy, D.; Junttila, M.R.; Pouyet, L.; Karnezis, A.; Shchors, K.; Bui, D.A.; Brown-Swigart, L.; Johnson, L.; Evan, G.I. Distinct Thresholds Govern Myc's Biological Output In Vivo. Cancer Cell 2008, 14, 447-457. [CrossRef]

55. McMahon, S.B. MYC and the Control of Apoptosis. Cold Spring Harb. Perspect. Med. 2014, 4, a014407. [CrossRef] [PubMed]

56. Yang, X.; Ye, H.; He, M.; Zhou, X.; Sun, N.; Guo, W.; Lin, X.; Huang, H.; Lin, Y.; Yao, R.; et al. LncRNA PDIA3P interacts with c-Myc to regulate cell proliferation via induction of pentose phosphate pathway in multiple myeloma. Biochem. Biophys. Res. Commun. 2018, 498, 207-213. [CrossRef] 
57. Bose, S.; Le, A. Glucose Metabolism in Cancer. Adv. Exp. Med. Biol. 2018, 1063, 3-12. [CrossRef]

58. Gan, L.; Xiu, R.; Ren, P.; Yue, M.; Su, H.; Guo, G.; Xiao, D.; Yu, J.; Jiang, H.; Liu, H.; et al. Metabolic targeting of oncogene MYC by selective activation of the proton-coupled monocarboxylate family of transporters. Oncogene 2016, 35, 3037-3048. [CrossRef] [PubMed]

59. Zhang, P.; Cao, L.; Fan, P.; Mei, Y.; Wu, M. Lnc RNA - MIF, a c-Myc-activated long non-coding RNA, suppresses glycolysis by promoting Fbxw7-mediated c-Myc degradation. EMBO Rep. 2016, 17, 1204-1220. [CrossRef]

60. Dong, Y.; Tu, R.; Liu, H.; Qing, G. Regulation of cancer cell metabolism: Oncogenic MYC in the driver's seat. Signal Transduct. Target. Ther. 2020, 5, 1-11. [CrossRef]

61. Osthus, R.C.; Shim, H.; Kim, S.; Li, Q.; Reddy, R.; Mukherjee, M.; Xu, Y.; Wonsey, D.; Lee, L.A.; Dang, C.V. Deregulation of Glucose Transporter 1 and Glycolytic Gene Expression by c-Myc. J. Biol. Chem. 2000, 275, 21797-21800. [CrossRef] [PubMed]

62. Mehla, K.; Singh, P.K. Metabolic Regulation of Macrophage Polarization in Cancer. Trends Cancer 2019, 5, 822-834. [CrossRef] [PubMed]

63. Casey, S.C.; Baylot, V.; Felsher, D.W. The MYC oncogene is a global regulator of the immune response. Blood 2018, 131, 2007-2015. [CrossRef]

64. Casey, S.C.; Tong, L.; Li, Y.; Do, R.; Walz, S.; Fitzgerald, K.N.; Gouw, A.; Baylot, V.; Gütgemann, I.; Eilers, M.; et al. MYC regulates the antitumor immune response through CD47 and PD-L1. Science 2016, 352, 227-231. [CrossRef]

65. Zhang, Y.; Zheng, J. Functions of Immune Checkpoint Molecules Beyond Immune Evasion. Adv. Exp. Med. Biol. 2020, 1248, 201-226. [CrossRef]

66. De Jonge, A.V.; Mutis, T.; Roemer, M.G.M.; Scheijen, B.; Chamuleau, M.E.D. Impact of MYC on Anti-Tumor Immune Responses in Aggressive B Cell Non-Hodgkin Lymphomas: Consequences for Cancer Immunotherapy. Cancers 2020, 12, 3052. [CrossRef] [PubMed]

67. Wolfer, A.; Ramaswamy, S. MYC and Metastasis: Figure 1. Cancer Res. 2011, 71, 2034-2037. [CrossRef]

68. Zhao, B.; Liu, L.; Mao, J.; Zhang, Z.; Wang, Q.; Li, Q. PIM1 mediates epithelial-mesenchymal transition by targeting Smads and c-Myc in the nucleus and potentiates clear-cell renal-cell carcinoma oncogenesis. Cell Death Dis. 2018, 9, 1-14. [CrossRef]

69. Zhuang, G.; Wu, X.; Jiang, Z.; Kasman, I.; Yao, J.; Guan, Y.; Oeh, J.; Modrusan, Z.; Bais, C.; Sampath, D.; et al. Tumour-secreted miR-9 promotes endothelial cell migration and angiogenesis by activating the JAK-STAT pathway. EMBO J. 2012, 31, 3513-3523. [CrossRef] [PubMed]

70. Chen, D.; Sun, Y.; Wei, Y.; Zhang, P.; Rezaeian, A.H.; Teruya-Feldstein, J.; Gupta, S.; Liang, H.; Lin, H.-K.; Hung, M.-C.; et al. LIFR is a breast cancer metastasis suppressor upstream of the Hippo-YAP pathway and a prognostic marker. Nat. Med. 2012, 18, 1511-1517. [CrossRef] [PubMed]

71. Rapp, U.R.; Korn, C.; Ceteci, F.; Karreman, C.; Luetkenhaus, K.; Serafin, V.; Zanucco, E.; Castro, I.; Potapenko, T. Myc Is a Metastasis Gene for Non-Small-Cell Lung Cancer. PLoS ONE 2009, 4, e6029. [CrossRef]

72. Lee, H.Y.; Cha, J.; Kim, S.K.; Park, J.H.; Song, K.H.; Kim, P.; Kim, M.-Y. c-MYC Drives Breast Cancer Metastasis to the Brain, but Promotes Synthetic Lethality with TRAIL. Mol. Cancer Res. 2019, 17, 544-554. [CrossRef]

73. Li, H.; Jin, Y.; Hu, Y.; Jiang, L.; Liu, F.; Zhang, Y.; Hao, Y.; Chen, S.; Wu, X.; Liu, Y. The PLGF /c- MYC /miR-19a axis promotes metastasis and stemness in gallbladder cancer. Cancer Sci. 2018, 109, 1532-1544. [CrossRef]

74. Song, G.; Li, Y.; Zhang, Z.; Ren, X.; Li, H.; Zhang, W.; Wei, R.; Pan, S.; Shi, L.; Bi, K.; et al. c-myc but not Hif-1 $\alpha$-dependent downregulation of VEGF influences the proliferation and differentiation of HL-60 cells induced by ATRA. Oncol. Rep. 2013, 29, 2378-2384. [CrossRef] [PubMed]

75. Chang, T.; Chu, P.; Hung, W.; Shan, Y.; Lin, H.; Huang, K.; Chang, J.S.; Chen, L.; Tsai, H. c-Myc promotes lymphatic metastasis of pancreatic neuroendocrine tumor through VEGFC upregulation. Cancer Sci. 2021, 112, 243-253. [CrossRef]

76. Dews, M.; Fox, J.L.; Hultine, S.; Sundaram, P.; Wang, E.; Liu, Y.Y.; Furth, E.; Enders, G.H.; Eldeiry, W.S.; Schelter, J.M.; et al. The Myc-miR-17 92 Axis Blunts TGF $\beta$ Signaling and Production of Multiple TGF $\beta$-Dependent Antiangiogenic Factors. Cancer Res. 2010, 70, 8233-8246. [CrossRef]

77. Fox, J.L.; Dews, M.; Minn, A.J.; Thomas-Tikhonenko, A. Targeting of TGF signature and its essential component CTGF by miR-18 correlates with improved survival in glioblastoma. RNA 2013, 19, 177-190. [CrossRef]

78. Wang, Y.-H.; Liu, S.; Zhang, G.; Zhou, C.-Q.; Zhu, H.-X.; Zhou, X.-B.; Quan, L.-P.; Bai, J.-F.; Xu, N.-Z. Knockdown of c-Myc expression by RNAi inhibits MCF-7 breast tumor cells growth in vitro and in vivo. Breast Cancer Res. 2005, 7, R220-R228. [CrossRef] [PubMed]

79. Zhang, X.; Ge, Y.-L.; Tian, R.-H. The knockdown of c-myc expression by RNAi inhibits cell proliferation in human colon cancer HT-29 cells in vitro and in vivo. Cell. Mol. Biol. Lett. 2009, 14, 305-318. [CrossRef]

80. Niu, Z.; Liu, H.; Zhou, M.; Wang, H.; Liu, Y.; Li, X.; Xiong, W.; Ma, J.; Li, G. Knockdown of c-Myc inhibits cell proliferation by negatively regulating the $\mathrm{Cdk} / \mathrm{Rb} / \mathrm{E} 2 \mathrm{~F}$ pathway in nasopharyngeal carcinoma cells. Acta Biochim. Et Biophys. Sin. 2015, 47, 183-191. [CrossRef] [PubMed]

81. Chen, H.; Liu, H.; Qing, G. Targeting oncogenic Myc as a strategy for cancer treatment. Signal Transduct. Target. Ther. 2018,3 , 5. [CrossRef]

82. Otto, C.; Schmidt, S.; Kastner, C.; Denk, S.; Kettler, J.; Müller, N.; Germer, C.; Wolf, E.; Gallant, P.; Wiegering, A. Targeting bromodomain-containing protein 4 (BRD4) inhibits MYC expression in colorectal cancer cells. Neoplasia 2019, 21, 1110-1120. [CrossRef] 
83. Zhang, Y.; Duan, S.; Jang, A.; Mao, L.; Liu, X.; Huang, G. JQ1, a selective inhibitor of BRD4, suppresses retinoblastoma cell growth by inducing cell cycle arrest and apoptosis. Exp. Eye Res. 2021, 202, 108304. [CrossRef] [PubMed]

84. Andrews, F.H.; Singh, A.R.; Joshi, S.; Smith, C.; Morales, G.; Garlich, J.R.; Durden, D.L.; Kutateladze, T.G. Dual-activity PI3KBRD4 inhibitor for the orthogonal inhibition of MYC to block tumor growth and metastasis. Proc. Natl. Acad. Sci. USA 2017, 114, E1072-E1080. [CrossRef] [PubMed]

85. Joshi, S.; Singh, A.R.; Liu, K.X.; Pham, T.V.; Zulcic, M.; Skola, D.; Chun, H.B.; Glass, C.K.; Morales, G.A.; Garlich, J.R.; et al. SF2523: Dual PI3K/BRD4 Inhibitor Blocks Tumor Immunosuppression and Promotes Adaptive Immune Responses in Cancer. Mol. Cancer Ther. 2019, 18, 1036-1044. [CrossRef]

86. Richart, L.; Pau, E.C.D.S.; Río-Machín, A.; de Andres, M.P.; Cigudosa, J.C.; Lobo, V.J.S.-A.; Real, F.X. BPTF is required for c-MYC transcriptional activity and in vivo tumorigenesis. Nat. Commun. 2016, 7, 10153. [CrossRef] [PubMed]

87. Xiong, L.; Mao, X.; Guo, Y.; Zhou, Y.; Chen, M.; Chen, P.; Yang, S.; Li, L. Discovery of selective BPTF bromodomain inhibitors by screening and structure-based optimization. Biochem. Biophys. Res. Commun. 2021, 545, 125-131. [CrossRef]

88. Liu, W.; Ma, W.; Yuan, Y.; Zhang, Y.; Sun, S. Circular RNA hsa_circRNA_103809 promotes lung cancer progression via facilitating ZNF121-dependent MYC expression by sequestering miR-4302. Biochem. Biophys. Res. Commun. 2018, 500, 846-851. [CrossRef]

89. Luo, A.; Zhang, X.; Fu, L.; Zhu, Z.; Dong, J.-T. Zinc finger factor ZNF121 is a MYC-interacting protein functionally affecting MYC and cell proliferation in epithelial cells. J. Genet. Genom. 2016, 43, 677-685. [CrossRef] [PubMed]

90. Yamashita, S.; Ogawa, K.; Ikei, T.; Fujiki, T.; Katakura, Y. FOXO3a Potentiates hTERT Gene Expression by Activating c-MYC and Extends the Replicative Life-Span of Human Fibroblast. PLoS ONE 2014, 9, e101864. [CrossRef]

91. Yagi, K.; Furuhashi, M.; Aoki, H.; Goto, D.; Kuwano, H.; Sugamura, K.; Miyazono, K.; Kato, M. c-myc Is a Downstream Target of the Smad Pathway. J. Biol. Chem. 2002, 277, 854-861. [CrossRef] [PubMed]

92. Wierstra, I.; Alves, J. The c-myc Promoter: Still MysterY and Challenge. Adv. Cancer Res. 2008, 99, 113-333. [CrossRef]

93. Huang, H.; Weng, H.; Sun, W.; Qin, X.; Shi, H.; Wu, H.; Zhao, B.S.; Mesquita, A.; Liu, C.; Yuan, C.L.; et al. Recognition of RNA N6-methyladenosine by IGF2BP proteins enhances mRNA stability and translation. Nat. Cell Biol. 2018, 20, 285-295. [CrossRef] [PubMed]

94. Liao, B.; Hu, Y.; Brewer, G. Competitive binding of AUF1 and TIAR to MYC mRNA controls its translation. Nat. Struct. Mol. Biol. 2007, 14, 511-518. [CrossRef] [PubMed]

95. Lu, M.; Pan, C.; Zhang, L.; Ding, C.; Chen, F.; Wang, Q.; Wang, K.; Zhang, X. ING4 inhibits the translation of proto-oncogene MYC by interacting with AUF1. FEBS Lett. 2013, 587, 1597-1604. [CrossRef]

96. Yeh, C.-H.; Bellon, M.; Nicot, C. FBXW7: A critical tumor suppressor of human cancers. Mol. Cancer 2018, 17, 1-19. [CrossRef]

97. Luo, L.; Tang, H.; Ling, L.; Li, N.; Jia, X.; Zhang, Z.; Wang, X.; Shi, L.; Yin, J.; Qiu, N.; et al. LINC01638 lncRNA activates MTDH-Twist1 signaling by preventing SPOP-mediated c-Myc degradation in triple-negative breast cancer. Oncogene 2018, 37, 6166-6179. [CrossRef]

98. Crawford, L.J.; Campbell, D.C.; Morgan, J.J.; Lawson, M.A.; Down, J.M.; Chauhan, D.; McAvera, R.M.; Morris, T.C.; Hamilton, C.; Krishnan, A.; et al. The E3 ligase HUWE1 inhibition as a therapeutic strategy to target MYC in multiple myeloma. Oncogene 2020, 39, 5001-5014. [CrossRef]

99. Sun, X.-X.; He, X.; Yin, L.; Komada, M.; Sears, R.C.; Dai, M.-S. The nucleolar ubiquitin-specific protease USP36 deubiquitinates and stabilizes c-Myc. Proc. Natl. Acad. Sci. USA 2015, 112, 3734-3739. [CrossRef]

100. Popov, N.; Wanzel, M.; Madiredjo, M.; Zhang, D.; Beijersbergen, R.; Bernards, R.; Moll, R.; Elledge, S.J.; Eilers, M. The ubiquitinspecific protease USP28 is required for MYC stability. Nat. Cell Biol. 2007, 9, 765-774. [CrossRef]

101. Itkonen, H.M.; Urbanucci, A.; Martin, S.E.; Khan, A.; Mathelier, A.; Thiede, B.; Walker, S.; Mills, I. High OGT activity is essential for MYC-driven proliferation of prostate cancer cells. Theranostics 2019, 9, 2183-2197. [CrossRef] [PubMed]

102. Itkonen, H.; Minner, S.; Guldvik, I.J.; Sandmann, M.J.; Tsourlakis, M.C.; Berge, V.; Svindland, A.; Schlomm, T.; Mills, I.G. O-GlcNAc Transferase Integrates Metabolic Pathways to Regulate the Stability of c-MYC in Human Prostate Cancer Cells. Cancer Res. 2013, 73, 5277-5287. [CrossRef] [PubMed]

103. Gu, Y.; Mi, W.; Ge, Y.; Liu, H.; Fan, Q.; Han, C.; Yang, J.; Han, F.; Lu, X.; Yu, W. GlcNAcylation Plays an Essential Role in Breast Cancer Metastasis. Cancer Res. 2010, 70, 6344-6351. [CrossRef] [PubMed]

104. Mi, W.; Gu, Y.; Han, C.; Liu, H.; Fan, Q.; Zhang, X.; Cong, Q.; Yu, W. O-GlcNAcylation is a novel regulator of lung and colon cancer malignancy. Biochim. Et Biophys. Acta BBA Mol. Basis Dis. 2011, 1812, 514-519. [CrossRef] [PubMed]

105. Böckelman, C.; Koskensalo, S.; Hagström, J.; Lundin, M.; Ristimäki, A.; Haglund, C. CIP2A overexpression is associated with c-Myc expression in colorectal cancer. Cancer Biol. Ther. 2012, 13, 289-295. [CrossRef]

106. Li, W.; Ge, Z.; Liu, C.; Liu, Z.; Björkholm, M.; Jia, J.; Xu, D. CIP2A Is Overexpressed in Gastric Cancer and Its Depletion Leads to Impaired Clonogenicity, Senescence, or Differentiation of Tumor Cells. Clin. Cancer Res. 2008, 14, 3722-3728. [CrossRef]

107. Vaarala, M.H.; Väisänen, M.-R.; Ristimäki, A. CIP2A expression is increased in prostate cancer. J. Exp. Clin. Cancer Res. 2010, 29, 136. [CrossRef]

108. Bedewy, A.M.; Elmaghraby, S.M. CIP2A expression in Bortezomib-treated multiple myeloma. J. BUON 2020, 25, 395-400.

109. Junttila, M.R.; Puustinen, P.; Niemelä, M.; Ahola, R.; Arnold, H.; Böttzauw, T.; Ala-Aho, R.; Nielsen, C.; Ivaska, J.; Taya, Y.; et al. CIP2A Inhibits PP2A in Human Malignancies. Cell 2007, 130, 51-62. [CrossRef] 
110. Russo, F.; Fiscon, G.; Conte, F.; Rizzo, M.; Paci, P.; Pellegrini, M. Interplay Between Long Noncoding RNAs and MicroRNAs in Cancer. In Methods in Molecular Biology; Springer Science and Business Media LLC: Berlin, Germany, 2018; Volume 1819, pp. 75-92.

111. Chen, X.; Fan, S.; Song, E. Noncoding RNAs: New Players in Cancers. Adv. Exp. Med. Biol. 2016, 927, 1-47. [CrossRef]

112. Dizaji, B.F. Strategies to target long non-coding RNAs in cancer treatment: Progress and challenges. Egypt. J. Med Hum. Genet. 2020, 21, 1-15. [CrossRef]

113. Zeng, M.-S.; Song, E. Noncoding RNAs in Cancer Diagnosis. Chem. Biol. Pteridines Folates 2016, 927, 391-427. [CrossRef]

114. Wei, J.T.; Feng, Z.; Partin, A.W.; Brown, E.; Thompson, I.; Sokoll, L.; Chan, D.W.; Lotan, Y.; Kibel, A.S.; Busby, J.E.; et al. Can Urinary PCA3 Supplement PSA in the Early Detection of Prostate Cancer? J. Clin. Oncol. 2014, 32, 4066-4072. [CrossRef] [PubMed]

115. Shao, Y.; Ye, M.; Jiang, X.; Sun, W.; Ding, X.; Liu, Z.; Ye, G.; Zhang, X.; Xiao, B.; Guo, J. Gastric juice long noncoding RNA used as a tumor marker for screening gastric cancer. Cancer 2014, 120, 3320-3328. [CrossRef] [PubMed]

116. Jung, H.M.; Patel, R.S.; Phillips, B.L.; Wang, H.; Cohen, D.M.; Reinhold, W.; Chang, L.-J.; Yang, L.-J.; Chan, E.K.L. Tumor suppressor miR-375 regulates MYC expression via repression of CIP2A coding sequence through multiple miRNA-mRNA interactions. Mol. Biol. Cell 2013, 24, 1638-1648. [CrossRef] [PubMed]

117. Liu, Y.; Huang, H.; Liu, M.; Wu, Q.; Li, W.; Zhang, J. MicroRNA-24-1 suppresses mouse hepatoma cell invasion and metastasis via directly targeting O -GlcNAc transferase. Biomed. Pharmacother. 2017, 91, 731-738. [CrossRef]

118. Kasinski, A.; Slack, F.J. MicroRNAs en route to the clinic: Progress in validating and targeting microRNAs for cancer therapy. Nat. Rev. Cancer 2011, 11, 849-864. [CrossRef]

119. Shams, R.; Aghdaei, H.A.; Behmanesh, A.; Sadeghi, A.; Zali, M.; Salari, S.; Padrón, J.M. MicroRNAs Targeting MYC Expression: Trace of Hope for Pancreatic Cancer Therapy. A Systematic Review. Cancer Manag. Res. 2020, 12, 2393-2404. [CrossRef] [PubMed]

120. Sampson, V.B.; Rong, N.H.; Han, J.; Yang, Q.; Aris, V.; Soteropoulos, P.; Petrelli, N.J.; Dunn, S.P.; Krueger, L.J. MicroRNA Let-7a Down-regulates MYC and Reverts MYC-Induced Growth in Burkitt Lymphoma Cells. Cancer Res. 2007, 67, 9762-9770. [CrossRef]

121. Bueno, M.J.; De Cedrón, M.G.; Gómez-López, G.; De Castro, I.P.; Di Lisio, L.; Montes-Moreno, S.; Martínez, N.; Guerrero, M.; Martínez, R.S.; Santos, J.; et al. Combinatorial effects of microRNAs to suppress the Myc oncogenic pathway. Blood 2011, 117, 6255-6266. [CrossRef]

122. Wang, J.; Zhao, X.; Shi, J.; Pan, Y.; Chen, Q.; Leng, P.; Wang, Y. miR-451 suppresses bladder cancer cell migration and invasion via directly targeting c-Myc. Oncol. Rep. 2016, 36, 2049-2058. [CrossRef] [PubMed]

123. Sun, T.; Wang, C.; Xing, J.; Wu, D. miR-429 Modulates the expression of c-myc in human gastric carcinoma cells. Eur. J. Cancer 2011, 47, 2552-2559. [CrossRef] [PubMed]

124. Yuan, Y.; Kluiver, J.; Koerts, J.; De Jong, D.; Rutgers, B.; Razak, F.R.A.; Terpstra, M.; Plaat, B.; Nolte, I.M.; Diepstra, A.; et al. miR-24-3p Is Overexpressed in Hodgkin Lymphoma and Protects Hodgkin and Reed-Sternberg Cells from Apoptosis. Am. J. Pathol. 2017, 187, 1343-1355. [CrossRef]

125. Su, B.; Xu, T.; Bruce, J.P.; Yip, K.W.; Zhang, N.; Huang, Z.; Zhang, G.; Liu, F.-F.; Liang, J.; Yang, H. hsa-miR-24 suppresses metastasis in nasopharyngeal carcinoma by regulating the c-Myc/epithelial-mesenchymal transition axis. Oncol. Rep. 2018, 40, 2536-2546. [CrossRef]

126. Khodadadi-Jamayran, A.; Akgol-Oksuz, B.; Afanasyeva, Y.; Heguy, A.; Thompson, M.; Ray, K.; Perafita, A.G.; Sánchez, I.; Wu, X.; Tripathy, D.; et al. Prognostic role of elevated mir-24-3p in breast cancer and its association with the metastatic process. Oncotarget 2018, 9, 12868-12878. [CrossRef]

127. Liu, D.; Dong, L.; Liu, Y.; Wen, D.; Gao, D.; Sun, H.-C.; Fan, J.; Wu, W. A c-Myc/miR-17-5p feedback loop regulates metastasis and invasion of hepatocellular carcinoma. Tumor Biol. 2016, 37, 5039-5047. [CrossRef]

128. Guo, Z.; Maki, M.; Ding, R.; Yang, Y.; Zhang, B.; Xiong, L. Genome-wide survey of tissue-specific microRNA and transcription factor regulatory networks in 12 tissues. Sci. Rep. 2014, 4, 5150. [CrossRef]

129. Tang, W.; Wan, S.; Yang, Z.; Teschendorff, A.E.; Zou, Q. Tumor origin detection with tissue-specific miRNA and DNA methylation markers. Bioinformatics 2018, 34, 398-406. [CrossRef] [PubMed]

130. Zhou, J.; Chan, Z.-L.; Bi, C.; Lu, X.; Chong, P.S.; Chooi, J.-Y.; Cheong, L.-L.; Liu, S.-C.; Ching, Y.Q.; Zhou, Y.; et al. LIN28B Activation by PRL-3 Promotes Leukemogenesis and a Stem Cell-like Transcriptional Program in AML. Mol. Cancer Res. 2017, 15, 294-303. [CrossRef]

131. Feng, C.; Neumeister, V.; Ma, W.; Xu, J.; Lu, L.; Bordeaux, J.; Maihle, N.J.; Rimm, D.L.; Huang, Y. Lin28 regulates HER2 and promotes malignancy through multiple mechanisms. Cell Cycle 2012, 11, 2486-2494. [CrossRef] [PubMed]

132. Xu, C.; Shen, J.; Xie, S.; Jiang, Z.; Huang, L.; Wang, L. Positive expression of Lin28 is correlated with poor survival in gastric carcinoma. Med Oncol. 2013, 30, 382. [CrossRef]

133. Qiu, J.-L.; Huang, P.-Z.; You, J.-H.; Zou, R.-H.; Wang, L.; Hong, J.; Li, B.-K.; Zhou, K.; Yuan, Y.-F. LIN28 expression and prognostic value in hepatocellular carcinoma patients who meet the Milan criteria and undergo hepatectomy. Chin. J. Cancer 2012, 31, 223-232. [CrossRef] [PubMed]

134. Diskin, S.J.; Capasso, M.; Schnepp, R.W.; Cole, K.A.; Attiyeh, E.F.; Hou, C.; Diamond, M.; Carpenter, E.L.; Winter, C.; Lee, H.; et al. Common variation at 6q16 within HACE1 and LIN28B influences susceptibility to neuroblastoma. Nat. Genet. 2012, 44, 1126-1130. [CrossRef] 
135. Albino, D.; Civenni, G.; Dallavalle, C.; Roos, M.; Jahns, H.; Curti, L.; Rossi, S.; Pinton, S.; D'Ambrosio, G.; Sessa, F.; et al. Activation of the Lin28/let-7 Axis by Loss of ESE3/EHF Promotes a Tumorigenic and Stem-like Phenotype in Prostate Cancer. Cancer Res. 2016, 76, 3629-3643. [CrossRef]

136. Bhat-Nakshatri, P.; Wang, G.; Collins, N.R.; Thomson, M.J.; Geistlinger, T.R.; Carroll, J.S.; Brown, M.; Hammond, S.; Srour, E.F.; Liu, Y.; et al. Estradiol-regulated microRNAs control estradiol response in breast cancer cells. Nucleic Acids Res. 2009, 37, 4850-4861. [CrossRef] [PubMed]

137. Zhou, W.; Ye, X.-L.; Xu, J.; Cao, M.-G.; Fang, Z.-Y.; Li, L.-Y.; Guan, G.-H.; Liu, Q.; Qian, Y.-H.; Xie, D. The lncRNA H19 mediates breast cancer cell plasticity during EMT and MET plasticity by differentially sponging miR-200b/c and let-7b. Sci. Signal. 2017, 10, eaak9557. [CrossRef] [PubMed]

138. Peng, F.; Li, T.-T.; Wang, K.-L.; Xiao, G.-Q.; Wang, J.-H.; Zhao, H.-D.; Kang, Z.-J.; Fan, W.-J.; Zhu, L.-L.; Li, M.; et al. H19/let7/LIN28 reciprocal negative regulatory circuit promotes breast cancer stem cell maintenance. Cell Death Dis. 2018, 8, e2569. [CrossRef] [PubMed]

139. Lan, F.-F.; Wang, H.; Chen, Y.; Chan, C.-Y.; Ng, S.S.; Li, K.; Xie, D.; He, M.-L.; Lin, M.C.; Kung, H.-F. Hsa-let-7g inhibits proliferation of hepatocellular carcinoma cells by downregulation of c-Myc and upregulation of p16INK4A. Int. J. Cancer 2010, 128, 319-331. [CrossRef] [PubMed]

140. Deng, L.; Yang, S.-B.; Xu, F.-F.; Zhang, J.-H. Long noncoding RNA CCAT1 promotes hepatocellular carcinoma progression by functioning as let-7 sponge. J. Exp. Clin. Cancer Res. 2015, 34, 1-10. [CrossRef]

141. He, X.-Y.; Chen, J.-X.; Zhang, Z.; Li, C.-L.; Peng, Q.; Peng, H.-M. The let-7a microRNA protects from growth of lung carcinoma by suppression of k-Ras and c-Myc in nude mice. J. Cancer Res. Clin. Oncol. 2009, 136, 1023-1028. [CrossRef]

142. Pang, M.; Wu, G.; Hou, X.; Hou, N.; Liang, L.; Jia, G.; Shuai, P.; Luo, B.; Wang, K.; Xiaolin, H. LIN28B Promotes Colon Cancer Migration and Recurrence. PLoS ONE 2014, 9, e109169. [CrossRef]

143. Akao, Y.; Nakagawa, Y.; Naoe, T. let-7 MicroRNA Functions as a Potential Growth Suppressor in Human Colon Cancer Cells. Biol. Pharm. Bull. 2006, 29, 903-906. [CrossRef]

144. Sun, S.; Sun, P.; Wang, C.; Sun, T. Downregulation of microRNA-155 accelerates cell growth and invasion by targeting c-myc in human gastric carcinoma cells. Oncol. Rep. 2014, 32, 951-956. [CrossRef]

145. He, W.; Li, Y.; Chen, X.; Lü, L.; Tang, B.; Wang, Z.; Pan, Y.; Cai, S.; He, Y.; Ke, Z. miR-494 acts as an anti-oncogene in gastric carcinoma by targeting c-myc. J. Gastroenterol. Hepatol. 2014, 29, 1427-1434. [CrossRef]

146. Chen, D.; Huang, J.; Zhang, K.; Pan, B.; Chen, J.; De, W.; Wang, R.; Chen, L. MicroRNA-451 induces epithelial-mesenchymal transition in docetaxel-resistant lung adenocarcinoma cells by targeting proto-oncogene c-Myc. Eur. J. Cancer 2014, 50, $3050-3067$. [CrossRef]

147. Roush, S.; Slack, F.J. The let-7 family of microRNAs. Trends Cell Biol. 2008, 18, 505-516. [CrossRef] [PubMed]

148. Zhou, J.-L.; Deng, S.; Fang, H.-S.; Yu, G.; Peng, H. Hsa-let-7g promotes osteosarcoma by reducing HOXB1 to activate NF-kB pathway. Biomed. Pharmacother. 2019, 109, 2335-2341. [CrossRef] [PubMed]

149. Chen, L.; Wang, W.; Cao, L.; Li, Z.; Wang, X. Long Non-Coding RNA CCAT1 Acts as a Competing Endogenous RNA to Regulate Cell Growth and Differentiation in Acute Myeloid Leukemia. Mol. Cells 2016, 39, 330-336. [CrossRef] [PubMed]

150. Chen, Q.; Yin, Q.; Mao, Y.; Zhang, Z.; Wu, S.; Cheng, Z.; Chen, X.; Xu, H.; Jin, S.; Jiang, H.; et al. Hsa_circ_0068307 mediates bladder cancer stem cell-like properties via miR-147/c-Myc axis regulation. Cancer Cell Int. 2020, 20, 1-10. [CrossRef]

151. Leucci, E.; Cocco, M.; Onnis, A.; De Falco, G.; Van Cleef, P.; Bellan, C.; Van Rijk, A.; Nyagol, J.; Byakika, B.; Lazzi, S.; et al. MYC translocation-negative classical Burkitt lymphoma cases: An alternative pathogenetic mechanism involving miRNA deregulation. J. Pathol. 2008, 216, 440-450. [CrossRef] [PubMed]

152. Yu, Z.; Wang, C.; Wang, M.; Li, Z.; Casimiro, M.C.; Liu, M.; Wu, K.; Whittle, J.; Ju, X.; Hyslop, T.; et al. A cyclin D1/microRNA 17/20 regulatory feedback loop in control of breast cancer cell proliferation. J. Cell Biol. 2008, 182, 509-517. [CrossRef]

153. Lujambio, A.; Calin, G.; Villanueva, A.; Ropero, S.; Sanchez-Cespedes, M.; Blanco, D.; Montuenga, L.; Rossi, S.; Nicoloso, M.; Faller, W.; et al. A microRNA DNA methylation signature for human cancer metastasis. Proc. Natl. Acad. Sci. USA 2008, 105, 13556-13561. [CrossRef]

154. Sachdeva, M.; Zhu, S.; Wu, F.; Wu, H.; Walia, V.; Kumar, S.; Elble, R.; Watabe, K.; Mo, Y.-Y. p53 represses c-Myc through induction of the tumor suppressor miR-145. Proc. Natl. Acad. Sci. USA 2009, 106, 3207-3212. [CrossRef] [PubMed]

155. Hsiao, K.-Y.; Lin, Y.-C.; Gupta, S.K.; Chang, N.; Yen, L.; Sun, H.S.; Tsai, S.-J. Noncoding Effects of Circular RNA CCDC66 Promote Colon Cancer Growth and Metastasis. Cancer Res. 2017, 77, 2339-2350. [CrossRef]

156. Wang, H.; Cao, F.; Li, X.; Miao, H.; E, J.; Xing, J.; Fu, C.-G. miR-320b suppresses cell proliferation by targeting c-Myc in human colorectal cancer cells. BMC Cancer 2015, 15, 1-9. [CrossRef]

157. Huang, W.; Tian, Y.; Dong, S.; Cha, Y.; Li, J.; Guo, X.; Yuan, X. The long non-coding RNA SNHG3 functions as a competing endogenous RNA to promote malignant development of colorectal cancer. Oncol. Rep. 2017, 38, 1402-1410. [CrossRef] [PubMed]

158. Lv, Z.; Wei, J.; You, W.; Wang, R.; Shang, J.; Xiong, Y.; Yang, H.; Yang, X.; Fu, Z. Disruption of the c-Myc/miR-200b-3p/PRDX2 regulatory loop enhances tumor metastasis and chemotherapeutic resistance in colorectal cancer. J. Transl. Med. 2017, 15, 1-18. [CrossRef]

159. Qian, C.-S.; Li, L.-J.; Huang, H.-W.; Yang, H.-F.; Wu, D.-P. MYC-regulated lncRNA NEAT1 promotes B cell proliferation and lymphomagenesis via the miR-34b-5p-GLI1 pathway in diffuse large B-cell lymphoma. Cancer Cell Int. 2020, 20, 1-13. [CrossRef] [PubMed] 
160. Xu, L.; Wang, F.; Xu, X.-F.; Mo, W.-H.; Xia, Y.-J.; Wan, R.; Wang, X.-P.; Guo, C.-Y. Down-regulation of miR-212 expression by DNA hypermethylation in human gastric cancer cells. Med. Oncol. 2010, 28, 189-196. [CrossRef] [PubMed]

161. Yin, H.; Song, P.; Su, R.; Yang, G.; Dong, L.; Luo, M.; Wang, B.; Gong, B.; Liu, C.; Song, W.; et al. DNA Methylation mediated down-regulating of MicroRNA-33b and its role in gastric cancer. Sci. Rep. 2016, 6, 18824. [CrossRef] [PubMed]

162. Zhang, Y.; Peng, Z.; Zhao, Y.; Chen, L. microRNA-25 Inhibits Cell Apoptosis of Human Gastric Adenocarcinoma Cell Line AGS via Regulating CCNE1 and MYC. Med. Sci. Monit. 2016, 22, 1415-1420. [CrossRef]

163. Yoon, J.H.; Choi, W.S.; Kim, O.; Choi, B.J.; Nam, S.W.; Lee, J.Y.; Park, W.S. Gastrokine 1 inhibits gastric cancer cell migration and invasion by downregulating RhoA expression. Gastric Cancer 2016, 20, 274-285. [CrossRef]

164. Qian, K.; Mao, B.; Zhang, W.; Chen, H. MicroRNA-561 inhibits gastric cancercell proliferation and invasion by downregulating c-Myc expression. Am. J. Transl. Res. 2016, 8, 3802-3811.

165. Dong, Y.; Li, X.; Lin, Z.; Zou, W.; Liu, Y.; Qian, H.; Jia, J. HOXC-AS1-MYC regulatory loop contributes to the growth and metastasis in gastric cancer. J. Exp. Clin. Cancer Res. 2019, 38, 1-14. [CrossRef]

166. Wang, S.; Tang, D.; Wang, W.; Yang, Y.; Wu, X.; Wang, L.; Wang, D. circLMTK2 acts as a sponge of miR-150-5p and promotes proliferation and metastasis in gastric cancer. Mol. Cancer 2019, 18,1-17. [CrossRef]

167. Du, W.; Li, D.; Guo, X.; Li, P.; Li, X.; Tong, S.; Tong, J.; Kuang, L.; Liang, D. Circ-PRMT5 promotes gastric cancer progression by sponging miR-145 and miR-1304 to upregulate MYC. Artif. Cells Nanomed. Biotechnol. 2019, 47, 4120-4130. [CrossRef] [PubMed]

168. Zhao, X.; Zhong, Q.; Cheng, X.; Wang, S.; Wu, R.; Leng, X.; Shao, L. miR-449c-5p availability is antagonized by circ-NOTCH1 for MYC-induced NOTCH1 upregulation as well as tumor metastasis and stemness in gastric cancer. J. Cell. Biochem. 2020, 121, 4052-4063. [CrossRef]

169. Chen, J.; Li, Y.; Zheng, Q.; Bao, C.; He, J.; Chen, B.; Lyu, D.; Zheng, B.; Xu, Y.; Long, Z.; et al. Circular RNA profile identifies circPVT1 as a proliferative factor and prognostic marker in gastric cancer. Cancer Lett. 2017, 388, 208-219. [CrossRef]

170. Ouyang, Q.; Chen, G.; Zhou, J.; Li, L.; Dong, Z.; Yang, R.; Xu, L.; Cui, H.; Xu, M.; Yi, L. Neurotensin signaling stimulates glioblastoma cell proliferation by upregulating c-Myc and inhibiting miR-29b-1 and miR-129-3p. Neuro Oncol. 2015, 18, 216-226. [CrossRef]

171. Ma, Y.; Zhou, G.; Li, M.; Hu, D.; Zhang, L.; Liu, P.; Lin, K. Long noncoding RNA DANCR mediates cisplatin resistance in glioma cells via activating AXL/PI3K/Akt/NF- KB signaling pathway. Neurochem. Int. 2018, 118, 233-241. [CrossRef] [PubMed]

172. Luo, W.; Sun, C.; Zhou, J.; Wang, Q.; Yu, L.; Bian, X.-W.; Zhou, X.; Hua, D.; Wang, R.; Rao, C.; et al. miR-135a-5p Functions as a Glioma Proliferation Suppressor by Targeting Tumor Necrosis Factor Receptor-Associated Factor 5 and Predicts Patients' Prognosis. Am. J. Pathol. 2019, 189, 162-176. [CrossRef]

173. Lo, W.-L.; Yu, C.-C.; Chiou, G.-Y.; Chen, Y.-W.; Huang, P.-I.; Chien, C.-S.; Tseng, L.-M.; Chu, P.-Y.; Lu, K.-H.; Chang, K.-W.; et al. MicroRNA-200c attenuates tumour growth and metastasis of presumptive head and neck squamous cell carcinoma stem cells. $J$. Pathol. 2011, 223, 482-495. [CrossRef] [PubMed]

174. Han, H.; Sun, D.; Li, W.; Shen, H.; Zhu, Y.; Li, C.; Chen, Y.; Lu, L.; Li, W.; Zhang, J.; et al. A c-Myc-MicroRNA functional feedback loop affects hepatocarcinogenesis. Hepatology 2013, 57, 2378-2389. [CrossRef]

175. Lin, F.; Ding, R.; Zheng, S.; Xing, D.; Hong, W.; Zhou, Z.; Shen, J. Decrease expression of microRNA-744 promotes cell proliferation by targeting c-Myc in human hepatocellular carcinoma. Cancer Cell Int. 2014, 14, 58. [CrossRef]

176. Tian, J.; Hu, X.; Gao, W.; Zhang, J.; Chen, M.; Zhang, X.; Ma, J.; Yuan, H. Identification a novel tumor-suppressive hsa-miR-599 regulates cells proliferation, migration and invasion by targeting oncogenic MYC in hepatocellular carcinoma. Am. J. Transl. Res. 2016, 8, 2575-2584.

177. Xie, F.; Yuan, Y.; Xie, L.; Ran, P.; Xiang, X.; Huang, Q.; Qi, G.; Guo, X.; Xiao, C.; Zheng, S. miRNA-320a inhibits tumor proliferation and invasion by targeting c-Myc in human hepatocellular carcinoma. OncoTargets Ther. 2017, 10, 885-894. [CrossRef]

178. Tran, D.D.H.; Kessler, C.; Niehus, S.E.; Mahnkopf, M.; Koch, A.; Tamura, T. Myc target gene, long intergenic noncoding RNA, Linc00176 in hepatocellular carcinoma regulates cell cycle and cell survival by titrating tumor suppressor microRNAs. Oncogene 2018, 37, 75-85. [CrossRef]

179. Wang, B.; Hsu, S.-H.; Wang, X.; Kutay, H.; Bid, H.K.; Yu, J.; Ganju, R.K.; Jacob, S.T.; Yuneva, M.; Ghoshal, K. Reciprocal regulation of microRNA-122 and c-Myc in hepatocellular cancer: Role of E2F1 and transcription factor dimerization partner 2. Hepatology 2013, 59, 555-566. [CrossRef]

180. Wei, X.; Zheng, W.; Tian, P.; He, Y.; Liu, H.; Peng, M.; Li, X.; Liu, X. Oncogenic hsa_circ_0091581 promotes the malignancy of HCC cell through blocking miR-526b from degrading c-MYC mRNA. Cell Cycle 2020, 19, 817-824. [CrossRef]

181. Chen, Z.; Zeng, H.; Guo, Y.; Liu, P.; Pan, H.; Deng, A.; Hu, J. miRNA-145 inhibits non-small cell lung cancer cell proliferation by targeting c-Myc. J. Exp. Clin. Cancer Res. 2010, 29, 151. [CrossRef]

182. Xi, S.; Xu, H.; Shan, J.; Tao, Y.; Hong, J.A.; Inchauste, S.; Zhang, M.; Kunst, T.F.; Mercedes, L.; Schrump, D.S. Cigarette smoke mediates epigenetic repression of miR-487b during pulmonary carcinogenesis. J. Clin. Investig. 2013, 123, 1241-1261. [CrossRef]

183. Miao, L.-J.; Huang, S.-F.; Sun, Z.-T.; Gao, Z.-Y.; Zhang, R.-X.; Liu, Y.; Wang, J. MiR-449c targets c-Myc and inhibits NSCLC cell progression. FEBS Lett. 2013, 587, 1359-1365. [CrossRef]

184. Bommer, G.; Gerin, I.; Feng, Y.; Kaczorowski, A.J.; Kuick, R.; Love, R.E.; Zhai, Y.; Giordano, T.; Qin, Z.; Moore, B.; et al. p53-Mediated Activation of miRNA34 Candidate Tumor-Suppressor Genes. Curr. Biol. 2007, 17, 1298-1307. [CrossRef] 
185. Hua, Q.; Jin, M.; Mi, B.; Xu, F.; Li, T.; Zhao, L.; Liu, J.; Huang, G. LINC01123, a c-Myc-activated long non-coding RNA, promotes proliferation and aerobic glycolysis of non-small cell lung cancer through miR-199a-5p/c-Myc axis. J. Hematol. Oncol. 2019, 12, 1-18. [CrossRef]

186. Takwi, A.A.L.; Li, Y.; Buscaglia, L.E.B.; Zhang, J.; Choudhury, S.; Park, A.K.; Liu, M.; Young, K.H.; Park, W.-Y.; Martin, R.C.G.; et al. A statin-regulated microRNA represses human c-Myc expression and function. EMBO Mol. Med. 2012, 4, 896-909. [CrossRef]

187. Min, D.-J.; Ezponda, T.; Kim, M.K.; Will, C.M.; Martinez-Garcia, E.; Popovic, R.; Basrur, V.; Elenitoba-Johnson, K.; Licht, J.D. MMSET stimulates myeloma cell growth through microRNA-mediated modulation of c-MYC. Leukemia 2012, 27, 686-694. [CrossRef]

188. Zhen, Y.; Liu, Z.; Yang, H.; Yu, X.; Wu, Q.; Hua, S.; Long, X.; Jiang, Q.; Song, Y.; Cheng, C.; et al. Tumor suppressor PDCD4 modulates miR-184-mediated direct suppression of C-MYC and BCL2 blocking cell growth and survival in nasopharyngeal carcinoma. Cell Death Dis. 2013, 4, e872. [CrossRef] [PubMed]

189. Shao, Y.; Qu, Y.; Dang, S.; Yao, B.; Ji, M. MiR-145 inhibits oral squamous cell carcinoma (OSCC) cell growth by targeting c-Myc and Cdk6. Cancer Cell Int. 2013, 13, 51. [CrossRef] [PubMed]

190. Arunkumar, G.; Rao, A.K.D.M.; Manikandan, M.; Arun, K.; Vinothkumar, V.; Revathidevi, S.; Rajkumar, K.S.; Rajaraman, R.; Munirajan, A.K. Expression profiling of long non-coding RNA identifies linc-RoR as a prognostic biomarker in oral cancer. Tumor Biol. 2017, 39, 1010428317698366. [CrossRef] [PubMed]

191. Zhao, W.; Cui, Y.; Liu, L.; Qi, X.; Liu, J.; Ma, S.; Hu, X.; Zhang, Z.; Wang, Y.; Li, H.; et al. Splicing factor derived circular RNA circUHRF1 accelerates oral squamous cell carcinoma tumorigenesis via feedback loop. Cell Death Differ. 2020, 27, 919-933. [CrossRef]

192. Benassi, B.; Flavin, R.; Marchionni, L.; Zanata, S.; Pan, Y.; Chowdhury, D.; Marani, M.; Strano, S.; Muti, P.; Blandino, G.; et al. MYC Is Activated by USP2a-Mediated Modulation of MicroRNAs in Prostate Cancer. Cancer Discov. 2012, 2, 236-247. [CrossRef]

193. Zhu, J.; Wang, S.; Zhang, W.; Qiu, J.; Shan, Y.; Yang, D.; Shen, B. Screening key microRNAs for castration-resistant prostate cancer based on miRNA/mRNA functional synergistic network. Oncotarget 2015, 6, 43819-43830. [CrossRef] [PubMed]

194. Aghdam, A.M.; Amiri, A.; Salarinia, R.; Masoudifar, A.; Ghasemi, F.; Mirzaei, H. MicroRNAs as Diagnostic, Prognostic, and Therapeutic Biomarkers in Prostate Cancer. Crit. Rev. Eukaryot. Gene Expr. 2019, 29, 127-139. [CrossRef]

195. Prensner, J.; Chen, W.; Han, S.; Iyer, M.K.; Cao, Q.; Kothari, V.; Evans, J.R.; Knudsen, K.; Paulsen, M.T.; Ljungman, M.; et al. The Long Non-Coding RNA PCAT-1 Promotes Prostate Cancer Cell Proliferation through cMyc. Neoplasia 2014, 16, 900-908. [CrossRef] [PubMed]

196. Mao, A.; Zhao, Q.; Zhou, X.; Sun, C.; Si, J.; Zhou, R.; Gan, L.; Zhang, H. MicroRNA-449a enhances radiosensitivity by downregulation of c-Myc in prostate cancer cells. Sci. Rep. 2016, 6, 27346. [CrossRef]

197. Zhao, M.; Qi, M.; Li, X.; Hu, J.; Zhang, J.; Jiao, M.; Bai, X.; Peng, X.; Han, B. CUL4B/miR-33b/C-MYC axis promotes prostate cancer progression. Prostate 2019, 79, 480-488. [CrossRef] [PubMed]

198. Wang, J.; Yang, X.; Li, R.; Wang, L.; Gu, Y.; Zhao, Y.; Huang, K.H.; Cheng, T.; Yuan, Y.; Gao, S. Long non-coding RNA MYU promotes prostate cancer proliferation by mediating the miR-184/c-Myc axis. Oncol. Rep. 2018, 40, 2814-2825. [CrossRef] [PubMed]

199. Yamamura, S.; Saini, S.; Majid, S.; Hirata, H.; Ueno, K.; Chang, I.; Tanaka, Y.; Gupta, A.; Dahiya, R. MicroRNA-34a suppresses malignant transformation by targeting c-Myc transcriptional complexes in human renal cell carcinoma. Carcinogenesis 2011, 33, 294-300. [CrossRef]

200. Li, X.; Sanda, T.; Look, A.T.; Novina, C.D.; Von Boehmer, H. Repression of tumor suppressor miR-451 is essential for NOTCH1induced oncogenesis in T-ALL. J. Exp. Med. 2011, 208, 663-675. [CrossRef]

201. Marques, J.C.; Ricarte-Filho, J.C.M.; Fuziwara, C.S.; Yamashita, A.S.; Rezende, E.; Da-Silva, M.J.; Kimura, E.T. Effects of let-7 microRNA on Cell Growth and Differentiation of Papillary Thyroid Cancer. Transl. Oncol. 2009, 2, 236-241. [CrossRef]

202. Takeshita, H.; Shiozaki, A.; Bai, X.-H.; Iitaka, D.; Kim, H.; Yang, B.B.; Keshavjee, S.; Liu, M. XB130, a New Adaptor Protein, Regulates Expression of Tumor Suppressive MicroRNAs in Cancer Cells. PLoS ONE 2013, 8, e59057. [CrossRef] [PubMed]

203. Balzeau, J.; Menezes, M.R.; Cao, S.; Hagan, J.P. The LIN28/let-7 Pathway in Cancer. Front. Genet. 2017, 8, 31. [CrossRef]

204. Cai, Q.; Medeiros, L.J.; Xu, X.; Young, K.H. MYC-driven aggressive B-cell lymphomas: Biology, entity, differential diagnosis and clinical management. Oncotarget 2015, 6, 38591-38616. [CrossRef]

205. Saha, M.N.; Abdi, J.; Yang, Y.; Chang, H. miRNA-29a as a tumor suppressor mediates PRIMA-1Met-induced anti-myeloma activity by targeting c-Myc. Oncotarget 2016, 7, 7149-7160. [CrossRef]

206. Sang, B.; Zhang, Y.; Guo, S.T.; Kong, L.F.; Cheng, Q.; Liu, G.; Thorne, R.F.; Zhang, X.D.; Jin, L.; Wu, M. Dual functions for OVAAL in initiation of RAF/MEK/ERK prosurvival signals and evasion of p27-mediated cellular senescence. Proc. Natl. Acad. Sci. USA 2018, 115, E11661-E11670. [CrossRef]

207. Deng, S.-J.; Chen, H.-Y.; Zeng, Z.; Deng, S.; Zhu, S.; Ye, Z.; He, C.; Liu, M.-L.; Huang, K.; Zhong, J.-X.; et al. Nutrient StressDysregulated Antisense lncRNA GLS-AS Impairs GLS-Mediated Metabolism and Represses Pancreatic Cancer Progression. Cancer Res. 2019, 79, 1398-1412. [CrossRef] [PubMed]

208. Nissan, A.; Stojadinovic, A.; Mitrani-Rosenbaum, S.; Halle, D.; Grinbaum, R.; Roistacher, M.; Bochem, A.; Dayanc, B.E.; Ritter, G.; Gomceli, I.; et al. Colon cancer associated transcript-1: A novel RNA expressed in malignant and pre-malignant human tissues. Int. J. Cancer 2012, 130, 1598-1606. [CrossRef] [PubMed] 
209. Cabanski, C.R.; White, N.M.; Dang, H.X.; Silva-Fisher, J.M.; Rauck, C.E.; Cicka, D.; Maher, C.A. Pan-cancer transcriptome analysis reveals long noncoding RNAs with conserved function. RNA Biol. 2015, 12, 628-642. [CrossRef]

210. Zhang, C.; Wang, W.; Lin, J.; Xiao, J.; Tian, Y. lncRNA CCAT1 promotes bladder cancer cell proliferation, migration and invasion. Int. Braz. J. Urol. 2019, 45, 549-559. [CrossRef] [PubMed]

211. You, Z.; Liu, C.; Wang, C.; Ling, Z.; Wang, Y.; Wang, Y.; Zhang, M.; Chen, S.; Xu, B.; Guan, H.; et al. LncRNA CCAT1 Promotes Prostate Cancer Cell Proliferation by Interacting with DDX5 and MIR-28-5P. Mol. Cancer Ther. 2019, 18, 2469-2479. [CrossRef]

212. Shan, L.; Liu, W.; Zhan, Y. Long Non-coding RNA CCAT1 Acts as an Oncogene and Promotes Sunitinib Resistance in Renal Cell Carcinoma. Front. Oncol. 2020, 10, 516552. [CrossRef] [PubMed]

213. He, X.; Tan, X.; Wang, X.; Jin, H.; Liu, L.; Ma, L.; Yu, H.; Fan, Z. C-Myc-activated long noncoding RNA CCAT1 promotes colon cancer cell proliferation and invasion. Tumor Biol. 2014, 35, 12181-12188. [CrossRef] [PubMed]

214. Ma, M.-Z.; Chu, B.-F.; Zhang, Y.; Weng, M.-Z.; Qin, Y.-Y.; Gong, W.; Quan, Z.-W. Long non-coding RNA CCAT1 promotes gallbladder cancer development via negative modulation of miRNA-218-5p. Cell Death Dis. 2015, 6, e1583. [CrossRef] [PubMed]

215. Liu, S.-P.; Yang, J.-X.; Cao, D.-Y.; Shen, K. Identification of differentially expressed long non-coding RNAs in human ovarian cancer cells with different metastatic potentials. Cancer Biol. Med. 2013, 10, 138-141. [CrossRef]

216. Wu, M.; Shen, J. From Super-Enhancer Non-coding RNA to Immune Checkpoint: Frameworks to Functions. Front. Oncol. 2019, 9 , 1307. [CrossRef]

217. Zhuang, C.; Ma, Q.; Zhuang, C.; Ye, J.; Zhang, F.; Gui, Y. LncRNA GClnc1 promotes proliferation and invasion of bladder cancer through activation of MYC. FASEB J. 2019, 33, 11045-11059. [CrossRef]

218. Jiang, Y.; Zhang, H.; Ke, J.; Shen, H.; Ou, H.; Liu, Y. Overexpression of LncRNA GHET1 predicts an unfavourable survival and clinical parameters of patients in various cancers. J. Cell. Mol. Med. 2019, 23, 4891-4899. [CrossRef]

219. Zhao, W.; Li, W.; Jin, X.; Niu, T.; Cao, Y.; Zhou, P.; Zheng, M. Silencing long non-coding RNA NEAT1 enhances the suppression of cell growth, invasion, and apoptosis of bladder cancer cells under cisplatin chemotherapy. Int. J. Clin. Exp. Pathol. 2019, 12, 549-558.

220. Zhuang, C.; Li, J.; Liu, Y.; Chen, M.; Yuan, J.; Fu, X.; Zhan, Y.; Liu, L.; Lin, J.; Zhou, Q.; et al. Tetracycline-inducible shRNA targeting long non-coding RNA PVT1 inhibits cell growth and induces apoptosis in bladder cancer cells. Oncotarget 2015, 6, 41194-41203. [CrossRef] [PubMed]

221. Wang, Z.; Yang, B.; Zhang, M.; Guo, W.; Wu, Z.; Wang, Y.; Jia, L.; Li, S.; Xie, W.; Yang, D.; et al. lncRNA Epigenetic Landscape Analysis Identifies EPIC1 as an Oncogenic lncRNA that Interacts with MYC and Promotes Cell-Cycle Progression in Cancer. Cancer Cell 2018, 33, 706-720.e9. [CrossRef]

222. Ma, F.; Liu, X.; Zhou, S.; Li, W.; Liu, C.; Chadwick, M.; Qian, C. Long non-coding RNA FGF13-AS1 inhibits glycolysis and stemness properties of breast cancer cells through FGF13-AS1/IGF2BPs/Myc feedback loop. Cancer Lett. 2019, 450, 63-75. [CrossRef]

223. Huang, J.; Zhang, A.; Ho, T.-T.; Zhang, Z.; Zhou, N.; Ding, X.; Zhang, X.; Xu, M.; Mo, Y.-Y. Linc-RoR promotes c-Myc expression through hnRNP I and AUF1. Nucleic Acids Res. 2016, 44, 3059-3069. [CrossRef] [PubMed]

224. Li, Y.; Cai, Q.; Li, W.; Feng, F.; Yang, L. Long non-coding RNA EPIC1 promotes cholangiocarcinoma cell growth. Biochem. Biophys. Res. Commun. 2018, 504, 654-659. [CrossRef]

225. Zeng, C.; Liu, S.; Lu, S.; Yu, X.; Lai, J.; Wu, Y.; Chen, S.; Wang, L.; Yu, Z.; Luo, G.; et al. The c-Myc-regulated lncRNA NEAT1 and paraspeckles modulate imatinib-induced apoptosis in CML cells. Mol. Cancer 2018, 17, 1-6. [CrossRef] [PubMed]

226. Ling, H.; Spizzo, R.; Atlasi, Y.; Nicoloso, M.; Shimizu, M.; Redis, R.S.; Nishida, N.; Gafà, R.; Song, J.; Guo, Z.; et al. CCAT2, a novel noncoding RNA mapping to 8q24, underlies metastatic progression and chromosomal instability in colon cancer. Genome Res. 2013, 23, 1446-1461. [CrossRef] [PubMed]

227. Tseng, Y.Y.; Moriarity, B.S.; Gong, W.; Akiyama, R.; Tiwari, A.; Kawakami, H.; Ronning, P.; Reuland, B.; Guenther, K.; Beadnell, T.C.; et al. PVT1 dependence in cancer with MYC copy-number increase. Nature 2014, 512, 82-86. [CrossRef]

228. Lv, Y.; Yang, X.; Wang, L. Effect of lncRNA THOR on proliferation and igration of colon cancer cells. Oncol. Lett. 2019, 18, 2518-2522. [CrossRef] [PubMed]

229. Wu, Q.; Wei, J.; Zhao, C.; Xiang, S.; Shi, M.; Wang, Y. Targeting LncRNA EPIC1 to inhibit human colon cancer cell progression. Aging 2020, 12. [CrossRef]

230. Zhou, J.; Li, X.; Wu, M.; Lin, C.; Guo, Y.; Tian, B. Knockdown of Long Noncoding RNA GHET1 Inhibits Cell Proliferation and Invasion of Colorectal Cancer. Oncol. Res. Featur. Preclin. Clin. Cancer Ther. 2016, 23, 303-309. [CrossRef] [PubMed]

231. Tang, J.; Yan, T.; Bao, Y.; Shen, C.; Yu, C.; Zhu, X.; Tian, X.; Guo, F.; Liang, Q.; Liu, Q.; et al. LncRNA GLCC1 promotes colorectal carcinogenesis and glucose metabolism by stabilizing c-Myc. Nat. Commun. 2019, 10, 1-15. [CrossRef]

232. Wang, Y.; Lu, J.-H.; Wu, Q.-N.; Jin, Y.; Wang, D.-S.; Chen, Y.-X.; Liu, J.; Luo, X.-J.; Meng, Q.; Pu, H.-Y.; et al. LncRNA LINRIS stabilizes IGF2BP2 and promotes the aerobic glycolysis in colorectal cancer. Mol. Cancer 2019, 18, 1-18. [CrossRef] [PubMed]

233. Zhu, Y.; Hu, H.; Yuan, Z.; Zhang, Q.; Xiong, H.; Hu, Z.; Wu, H.; Huang, R.; Wang, G.; Tang, Q. LncRNA NEAT1 remodels chromatin to promote the 5-Fu resistance by maintaining colorectal cancer stemness. Cell Death Dis. 2020, 11, 1-11. [CrossRef] [PubMed]

234. Liu, Z.; Gu, Y.; Cheng, X.; Jiang, H.; Huang, Y.; Zhang, Y.; Yu, G.; Cheng, Y.; Zhou, L. Upregulation lnc-NEAT1 contributes to colorectal cancer progression through sponging miR-486-5p and activating NR4A1/Wnt/ $\beta$-catenin pathway. Cancer Biomark. 2021, 30, 309-319. [CrossRef] [PubMed] 
235. Gao, Q.; Zhou, R.; Meng, Y.; Duan, R.; Wu, L.; Li, R.; Deng, F.; Lin, C.; Zhao, L. Long noncoding RNA CMPK2 promotes colorectal cancer progression by activating the FUBP3-c-Myc axis. Oncogene 2020, 39, 3926-3938. [CrossRef] [PubMed]

236. Li, Z.; Wei, D.; Yang, C.; Sun, H.; Lu, T.; Kuang, D. Overexpression of long noncoding RNA, NEAT1 promotes cell proliferation, invasion and migration in endometrial endometrioid adenocarcinoma. Biomed. Pharmacother. 2016, 84, 244-251. [CrossRef]

237. Yang, F.; Xue, X.; Bi, J.; Zheng, L.; Zhi, K.; Gu, Y.; Fang, G. Long noncoding RNA CCAT1, which could be activated by c-Myc, promotes the progression of gastric carcinoma. J. Cancer Res. Clin. Oncol. 2012, 139, 437-445. [CrossRef]

238. Zhang, X.; Bo, P.; Liu, L.; Zhang, X.; Li, J. Overexpression of long non-coding RNA GHET1 promotes the development of multidrug resistance in gastric cancer cells. Biomed. Pharmacother. 2017, 92, 580-585. [CrossRef]

239. Sur, S.; Nakanishi, H.; Steele, R.; Ray, R.B. Depletion of PCAT-1 in head and neck cancer cells inhibits tumor growth and induces apoptosis by modulating c-Myc-AKT1-p38 MAPK signalling pathways. BMC Cancer 2019, 19, 1-9. [CrossRef] [PubMed]

240. Jiang, B.; Yang, B.; Wang, Q.; Zheng, X.; Guo, Y.; Lu, W. lncRNA PVT1 promotes hepatitis B virus-positive liver cancer progression by disturbing histone methylation on the c-Myc promoter. Oncol. Rep. 2019, 43, 718-726. [CrossRef] [PubMed]

241. Liu, Y.; Wang, D.; Li, Y.; Yan, S.; Dang, H.; Yue, H.; Ling, J.; Chen, F.; Zhao, Y.; Gou, L.; et al. Long noncoding RNA CCAT2 promotes hepatocellular carcinoma proliferation and metastasis through up-regulation of NDRG1. Exp. Cell Res. 2019, 379, 19-29. [CrossRef]

242. Guo, X.; Hua, Y. CCAT1: An oncogenic long noncoding RNA in human cancers. J. Cancer Res. Clin. Oncol. 2016, 143, 555-562. [CrossRef] [PubMed]

243. Zhang, B.; Lu, H.-Y.; Xia, Y.-H.; Jiang, A.-G.; Lv, Y.-X. Long non-coding RNA EPIC1 promotes human lung cancer cell growth. Biochem. Biophys. Res. Commun. 2018, 503, 1342-1348. [CrossRef]

244. Yang, Y.-R.; Zang, S.-Z.; Zhong, C.-L.; Li, Y.-X.; Zhao, S.-S.; Feng, X.-J. Increased expression of the lncRNA PVT1 promotes tumorigenesis in non-small cell lung cancer. Int. J. Clin. Exp. Pathol. 2014, 7, 6929-6935.

245. Olivero, C.E.; Martínez-Terroba, E.; Zimmer, J.; Liao, C.; Tesfaye, E.; Hooshdaran, N.; Schofield, J.; Bendor, J.; Fang, D.; Simon, M.D.; et al. p53 Activates the Long Noncoding RNA Pvt1b to Inhibit Myc and Suppress Tumorigenesis. Mol. Cell 2020, 77, 761-774.e8. [CrossRef]

246. Hosono, Y.; Niknafs, Y.S.; Prensner, J.R.; Iyer, M.K.; Dhanasekaran, S.M.; Mehra, R.; Pitchiaya, S.; Tien, J.; Escara-Wilke, J.; Poliakov, A.; et al. Oncogenic Role of THOR, a Conserved Cancer/Testis Long Non-coding RNA. Cell 2017, 171, 1559-1572.e20. [CrossRef] [PubMed]

247. Wang, S.-S.; Lv, Y.; Xu, X.-C.; Zuo, Y.; Song, Y.; Wu, G.-P.; Lu, P.-H.; Zhang, Z.-Q.; Chen, M.-B. Triptonide inhibits human nasopharyngeal carcinoma cell growth via disrupting Lnc-RNA THOR-IGF2BP1 signaling. Cancer Lett. 2019, 443, 13-24. [CrossRef] [PubMed]

248. Wang, M.; Wang, L.; He, X.; Zhang, J.; Zhu, Z.; Zhang, M.; Li, X. lncRNA CCAT2 promotes radiotherapy resistance for human esophageal carcinoma cells via the miR-145/p70S6K1 and p53 pathway. Int. J. Oncol. 2019, 56, 327-336. [CrossRef] [PubMed]

249. Sahebi, R.; Malakootian, M.; Balalaee, B.; Shahryari, A.; Khoshnia, M.; Abbaszadegan, M.R.; Moradi, A.; Mowla, S.J. Linc-ROR and its spliced variants 2 and 4 are significantly up-regulated in esophageal squamous cell carcinoma. Iran. J. Basic Med. Sci 2016, $19,1131-1135$.

250. Yan, L.; Wu, X.; Yin, X.; Du, F.; Liu, Y.; Ding, X. LncRNA CCAT2 promoted osteosarcoma cell proliferation and invasion. J. Cell. Mol. Med. 2018, 22, 2592-2599. [CrossRef]

251. Chen, W.; Chen, M.; Xu, Y.; Chen, X.; Zhou, P.; Zhao, X.; Pang, F.; Liang, W. Long non-coding RNA THOR promotes human osteosarcoma cell growth in vitro and in vivo. Biochem. Biophys. Res. Commun. 2018, 499, 913-919. [CrossRef]

252. Wang, Y.; Zhang, M.; Wang, Z.; Guo, W.; Yang, D. MYC-binding lncRNA EPIC1 promotes AKT-mTORC1 signaling and rapamycin resistance in breast and ovarian cancer. Mol. Carcinog. 2020, 59, 1188-1198. [CrossRef] [PubMed]

253. Wang, L.; Zhou, S.; Guo, B. Vitamin D Suppresses Ovarian Cancer Growth and Invasion by Targeting Long Non-Coding RNA CCAT2. Int. J. Mol. Sci. 2020, 21, 2334. [CrossRef] [PubMed]

254. Napoli, S.; Piccinelli, V.; Mapelli, S.N.; Pisignano, G.; Catapano, C.V. Natural antisense transcripts drive a regulatory cascade controlling c-MYC transcription. RNA Biol. 2017, 14, 1742-1755. [CrossRef]

255. Hung, C.-L.; Wang, L.-Y.; Yu, Y.-L.; Chen, H.-W.; Srivastava, S.; Petrovics, G.; Kung, H.-J. A long noncoding RNA connects c-Myc to tumor metabolism. Proc. Natl. Acad. Sci. USA 2014, 111, 18697-18702. [CrossRef] [PubMed]

256. Xiao, Z.-D.; Han, L.; Lee, H.; Zhuang, L.; Zhang, Y.; Baddour, J.; Nagrath, D.; Wood, C.G.; Gu, J.; Wu, X.; et al. Energy stressinduced lncRNA FILNC1 represses c-Myc-mediated energy metabolism and inhibits renal tumor development. Nat. Commun. 2017, 8, 1-13. [CrossRef]

257. Ye, X.-T.; Huang, H.; Huang, W.-P.; Hu, W.-L. LncRNA THOR promotes human renal cell carcinoma cell growth. Biochem. Biophys. Res. Commun. 2018, 501, 661-667. [CrossRef] [PubMed]

258. Shang, Y. LncRNA THOR acts as a retinoblastoma promoter through enhancing the combination of c-myc mRNA and IGF2BP1 protein. Biomed. Pharmacother. 2018, 106, 1243-1249. [CrossRef]

259. Kozłowska, J.; Kozioł, K.; Stasiak, M.; Obacz, J.; Guglas, K.; Poter, P.; Mackiewicz, A.; Kolenda, T. The role of NEAT1 lncRNA in squamous cell carcinoma of the head and neck is still difficult to define. Wspótczesna Onkologia 2020, 24, 96-105. [CrossRef]

260. Łaźniak, S.; Lutkowska, A.; Wareńczak-Florczak, Ż.; Sowińska, A.; Tsibulski, A.; Roszak, A.; Sajdak, S.; Jagodziński, P.P. The association of CCAT2 rs6983267 SNP with MYC expression and progression of uterine cervical cancer in the Polish population. Arch. Gynecol. Obstet. 2018, 297, 1285-1292. [CrossRef] 
261. Fox, A.H.; Lamond, A. Paraspeckles. Cold Spring Harb. Perspect. Biol. 2010, 2, a000687. [CrossRef]

262. Yang, F.; Xue, X.; Zheng, L.; Bi, J.; Zhou, Y.; Zhi, K.; Gu, Y.; Fang, G. Long non-coding RNA GHET1 promotes gastric carcinoma cell proliferation by increasing c-Myc mRNA stability. FEBS J. 2014, 281, 802-813. [CrossRef] [PubMed]

263. Cui, M.; You, L.; Ren, X.; Zhao, W.; Liao, Q.; Zhao, Y. Long non-coding RNA PVT1 and cancer. Biochem. Biophys. Res. Commun. 2016, 471, 10-14. [CrossRef]

264. Xie, J.; Wang, X.; Proud, C.G. mTOR inhibitors in cancer therapy. F1000Research 2016, 5, 2078. [CrossRef]

265. Jeck, W.R.; Sorrentino, J.A.; Wang, K.; Slevin, M.K.; Burd, C.E.; Liu, J.; Marzluff, W.F.; Sharpless, E.N. Circular RNAs are abundant, conserved, and associated with ALU repeats. RNA 2012, 19, 141-157. [CrossRef]

266. Pamudurti, N.R.; Bartok, O.; Jens, M.; Ashwal-Fluss, R.; Stottmeister, C.; Ruhe, L.; Hanan, M.; Wyler, E.; Perez-Hernandez, D.; Ramberger, E.; et al. Translation of CircRNAs. Mol. Cell 2017, 66, 9-21.e7. [CrossRef]

267. Ghafouri-Fard, S.; Omrani, M.D.; Taheri, M. Long noncoding RNA PVT1: A highly dysregulated gene in malignancy. J. Cell. Physiol. 2020, 235, 818-835. [CrossRef] [PubMed]

268. Xu, G.; Chen, Y.; Fu, M.; Zang, X.; Cang, M.; Niu, Y.; Zhang, W.; Zhang, Y.; Mao, Z.; Shao, M.; et al. Circular RNA CCDC66 promotes gastric cancer progression by regulating c-Myc and TGF- $\beta$ signaling pathways. J. Cancer 2020, 11, 2759-2768. [CrossRef] [PubMed]

269. Sun, J.; Zhang, H.; Tao, D.; Xie, F.; Liu, F.; Gu, C.; Wang, M.; Wang, L.; Jiang, G.; Wang, Z.; et al. CircCDYL inhibits the expression of C-MYC to suppress cell growth and migration in bladder cancer. Artif. Cells Nanomed. Biotechnol. 2019, 47, 1349-1356. [CrossRef]

270. Xie, F.; Xiao, X.; Tao, D.; Huang, C.; Wang, L.; Liu, F.; Zhang, H.; Niu, H.; Jiang, G. circNR3C1 Suppresses Bladder Cancer Progression through Acting as an Endogenous Blocker of BRD4/C-myc Complex. Mol. Ther. Nucleic Acids 2020, 22, 510-519. [CrossRef]

271. Yang, Q.; Du, W.W.; Wu, N.; Yang, W.; Awan, F.M.; Fang, L.; Ma, J.; Li, X.; Zeng, Y.; Yang, Z.; et al. A circular RNA promotes tumorigenesis by inducing c-myc nuclear translocation. Cell Death Differ. 2017, 24, 1609-1620. [CrossRef] [PubMed]

272. Zhan, W.; Liao, X.; Wang, Y.; Li, L.; Li, J.; Chen, Z.; Tian, T.; He, J. circCTIC1 promotes the self-renewal of colon TICs through BPTF-dependent c-Myc expression. Carcinogenesis 2019, 40, 560-568. [CrossRef]

273. Cai, J.; Chen, Z.; Wang, J.; Wang, J.; Chen, X.; Liang, L.; Huang, M.; Zhang, Z.; Zuo, X. circHECTD1 facilitates glutaminolysis to promote gastric cancer progression by targeting miR-1256 and activating $\beta$-catenin/c-Myc signaling. Cell Death Dis. 2019, 10, 1-15. [CrossRef]

274. Yang, Y.; Gao, X.; Zhang, M.; Yan, S.; Sun, C.; Xiao, F.; Huang, N.; Yang, X.; Zhao, K.; Zhou, H.; et al. Novel Role of FBXW7 Circular RNA in Repressing Glioma Tumorigenesis. J. Natl. Cancer Inst. 2018, 110, 304-315. [CrossRef] [PubMed]

275. Shen, S.; Yao, T.; Xu, Y.; Zhang, D.; Fan, S.; Ma, J. CircECE1 activates energy metabolism in osteosarcoma by stabilizing c-Myc. Mol. Cancer 2020, 19, 1-17. [CrossRef]

276. Wang, M.; Chen, B.; Ru, Z.; Cong, L. CircRNA circ-ITCH suppresses papillary thyroid cancer progression through miR-223p/CBL/ $\beta$-catenin pathway. Biochem. Biophys. Res. Commun. 2018, 504, 283-288. [CrossRef]

277. Bi, W.; Huang, J.; Nie, C.; Liu, B.; He, G.; Han, J.; Pang, R.; Ding, Z.; Xu, J.; Zhang, J. CircRNA circRNA_102171 promotes papillary thyroid cancer progression through modulating CTNNBIP1-dependent activation of $\beta$-catenin pathway. J. Exp. Clin. Cancer Res. 2018, 37, 1-9. [CrossRef] [PubMed]

278. Dang, C.V. MYC on the Path to Cancer. Cell 2012, 149, 22-35. [CrossRef] [PubMed]

279. Kalkat, M.; De Melo, J.; Hickman, K.A.; Lourenco, C.; Redel, C.; Resetca, D.; Tamachi, A.; Tu, W.B.; Penn, L.Z. MYC Deregulation in Primary Human Cancers. Genes 2017, 8, 151. [CrossRef] [PubMed]

280. Truica, M.I.; Burns, M.C.; Han, H.; Abdulkadir, S.A. Turning Up the Heat on MYC: Progress in Small-Molecule Inhibitors. Cancer Res. 2021, 81, 248-253. [CrossRef]

281. Nair, S.K.; Burley, S.K. X-Ray Structures of Myc-Max and Mad-Max Recognizing DNA: Molecular Bases of Regulation by Proto-Oncogenic Transcription Factors. Cell 2003, 112, 193-205. [CrossRef]

282. Han, H.; Jain, A.D.; Truica, M.I.; Izquierdo-Ferrer, J.; Anker, J.; Lysy, B.; Sagar, V.; Luan, Y.; Chalmers, Z.R.; Unno, K.; et al. Small-Molecule MYC Inhibitors Suppress Tumor Growth and Enhance Immunotherapy. Cancer Cell 2019, 36, 483-497.e15. [CrossRef] [PubMed]

283. Xiao, Y.; Shi, K.; Qu, Y.; Chu, B.; Qian, Z. Engineering Nanoparticles for Targeted Delivery of Nucleic Acid Therapeutics in Tumor. Mol. Ther. Methods Clin. Dev. 2019, 12, 1-18. [CrossRef] [PubMed]

284. Singh, A.; Trivedi, P.; Jain, N.K. Advances in siRNA delivery in cancer therapy. Artif. Cells Nanomed. Biotechnol. 2018, 46, 274-283. [CrossRef] [PubMed] 